\title{
Renewable Energy Opportunities at Fort Drum, New York
}

\author{
SA Brown JR Hand \\ AC Orrell BJ Russo \\ AE Solana MR Weimar \\ JL Williamson SE Rowley \\ RJ Nesse, Project Manager
}

October 2010

\section{Pacific Northwest}

NATIONAL LABORATORY

Proudly Operated by Battelle Since 1965 


\title{
DISCLAIMER
}

This report was prepared as an account of work sponsored by an agency of the United States Government. Neither the United States Government nor any agency thereof, nor Battelle Memorial Institute, nor any of their employees, makes any warranty, express or implied, or assumes any legal liability or responsibility for the accuracy, completeness, or usefulness of any information, apparatus, product, or process disclosed, or represents that its use would not infringe privately owned rights. Reference herein to any specific commercial product, process, or service by trade name, trademark, manufacturer, or otherwise does not necessarily constitute or imply its endorsement, recommendation, or favoring by the United States Government or any agency thereof, or Battelle Memorial Institute. The views and opinions of authors expressed herein do not necessarily state or reflect those of the United States Government or any agency thereof.

\author{
PACIFIC NORTHWEST NATIONAL LABORATORY \\ operated by \\ BATTELLE \\ for the \\ UNITED STATES DEPARTMENT OF ENERGY \\ under Contract DE-AC05-76RL01830
}

Printed in the United States of America

Available to DOE and DOE contractors from the

Office of Scientific and Technical Information,

P.O. Box 62, Oak Ridge, TN 37831-0062;

ph: (865) 576-8401

fax: (865) 576-5728

email: reports@adonis.osti.gov

\author{
Available to the public from the National Technical Information Service, \\ U.S. Department of Commerce, 5285 Port Royal Rd., Springfield, VA 22161 \\ ph: (800) 553-6847 \\ fax: (703) 605-6900 \\ email: orders@ntis.fedworld.gov \\ online ordering: http://www.ntis.gov/ordering.htm
}

This document was printed on recycled paper. 


\title{
Renewable Energy Opportunities at Fort Drum, New York
}

\author{
SA Brown JR Hand \\ AC Orrell BJ Russo \\ AE Solana MR Weimar \\ JL Williamson SE Rowley* \\ RJ Nesse, Program Manager
}

October 2010

Prepared for

the U.S. Army Installation Management Command Headquarters under Contract DE-AC05-76RL01830

Related Services

Pacific Northwest National Laboratory

Richland, Washington 99352

*Fort Drum 



\section{Executive Summary}

This document provides an overview of renewable resource potential at Fort Drum, based primarily upon analysis of secondary data sources supplemented with limited on-site evaluations. This effort focuses on grid-connected generation of electricity from renewable energy sources and also on ground source heat pumps for heating and cooling buildings. The effort was funded by the U.S. Army Installation Management Command (IMCOM) as follow-on to the 2005 Department of Defense (DoD) Renewables Assessment. The site visit to Fort Drum took place on May 4 and 5, 2010.

At the current time, there are several renewable technologies that show economic potential at Fort Drum. Project feasibility is based on installation-specific resource availability and energy costs and projections based on accepted life-cycle cost methods. The most promising opportunity is the continued use of ground source heat pumps (GSHPs). The conversion of the retired coal plant to a biomass energy plant shows potential, along with a large-scale wind energy project and a waste-to-energy (WTE) project, although large-scale wind is not currently supported at Fort Drum and a WTE project may have regulatory and political issues.

\section{Ground Source Heat Pumps (GSHP)}

GSHP retrofits were analyzed using data from a 2002 Pacific Northwest National Laboratory (PNNL) data-gathering trip and generic Army buildings that represent post-2002 construction. Fort Drum does not have an ideal climate for GSHPs because of the dominant heating season, but both analysis approaches show there are some opportunities for retrofits. In general, buildings need to be air-conditioned to have cost-effective GSHP projects. For buildings constructed before 2002, open-loop systems were found to be the most cost-effective, followed by horizontal and then vertical. However, open-loop systems may not be allowed because of concerns about groundwater contamination and heat exchanger maintenance requirements. For typical buildings constructed after 2002, GSHPs are almost exclusively cost-effective using appropriated funding; those opportunities are primarily in small buildings. Simple paybacks for all scenarios range from 3 to 16 years.

\section{Biomass}

Fort Drum has received an unsolicited proposal to provide Fort Drum electricity generated from a woody biomass facility located on land leased from Fort Drum. The proposal requires that the retired coal plant on site be converted to a biomass energy plant. While there are a number of concerns with the proposal, it is, for now, the only potentially feasible option for biomass and large-scale renewable energy generation at Fort Drum. It is recommended to proceed with the verification of assumptions and investigation into legal issues required for implementation.

\section{Wind}

Fort Drum has a low to moderate wind resource and given the current cost assumptions, a largescale wind energy project at Fort Drum has marginal economics. The cost of energy required to achieve a $10 \%$ internal rate of return (IRR) is double what Fort Drum is currently paying. It is not recommended that Fort Drum pursue a large-scale wind energy project at this time. 
However, if capital costs were to decrease or if more incentives become available, Fort Drum should reconsider large-scale wind. Small-scale wind has low economic potential as well, including at the remote Non-Commissioned Officers (NCO) Academy site, because of the higher capital costs and lower energy production of small systems.

\section{Waste-to-Energy}

There is sufficient municipal solid waste (MSW) in the area to build an economic waste-toenergy plant on Fort Drum; however, the regulations about the import of MSW on site in Army Regulation 420-1 must be thoroughly examined. Projects using waste from the Jefferson County Transfer Station (4 MW) and the Development Authority of the North Country (DANC) Rodman Landfill (15 MW) were considered. Based on using combustion technology, the projects would have savings-to-investment ratios ranging from 1.5 to 2.2 , and IRRs ranging from $11 \%$ to almost $17 \%$, depending on the size of the plant.

\section{Other Renewable Resources}

Other renewable technologies did not prove to be cost-effective with current conditions and assumptions. Large biomass generation projects using mill residue, landfill gas, and wastewater treatment plant sludge are impractical at this time because of insufficient feedstock availability. Projects involving the use of biomass fuels such as crop residues, animal waste, and dedicated energy crops are also not feasible because of their inability to support economic electricity generation.

Solar projects are not likely to be cost-effective in the near future either, requiring an energy cost of about $45 \$ / \mathrm{kWh}$ to achieve a $10 \%$ IRR. There is no known high-temperature geothermal resource on Fort Drum.

Renewable resources with at least some potential for being economic are summarized in Table 1. If Fort Drum were to develop the proposed 38-MW biomass project, it could provide more than the site's average FY 2009 load of 20 MW. One large-scale wind turbine could provide 3,461 MWh/year, or just under 3\% of Fort Drum's FY 2009 electricity consumption. GSHPs save rather than generate energy; therefore, their impact on the total site consumption would be minimal.

Increasing use of renewable energy makes sense for the Army. The goal of this report is to help Army personnel make sense of renewable energy at Fort Drum. 
Table 1: Summary of Promising Renewable Energy Projects at Fort Drum

\begin{tabular}{|c|c|c|c|c|c|c|c|c|}
\hline & \begin{tabular}{||c|} 
Renewable \\
Resource and \\
Technology \\
\end{tabular} & $\begin{array}{c}\text { Resource } \\
\text { Estimate }\end{array}$ & $\begin{array}{l}\text { Earliest } \\
\text { Output }\end{array}$ & Figures of Merit & \begin{tabular}{|c|} 
Financing \\
Mechanisms \\
Evaluated \\
\end{tabular} & $\begin{array}{c}\text { Location } \\
\text { Requirements }\end{array}$ & Key Assumptions & $\begin{array}{l}\text { Next Steps I } \\
\text { Comments }\end{array}$ \\
\hline 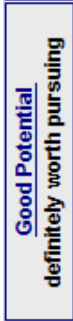 & \begin{tabular}{|l} 
Ground Source \\
Heat Pump \\
(Thermal \\
Energy)
\end{tabular} & TBD & 2011 & $\begin{array}{c}\text { ECIP scenario: } 6.1- \\
16.2 \text { year payback for } \\
\text { pre-2002 } \\
\text { construction, } 3.1-14.1 \\
\text { years for post-2002 } \\
\text { UESC/ESPC } \\
\text { scenario: } 6.4-16.0 \\
\text { year payback for pre- } \\
2002 \text { construction, } 8.2 \\
\text { years for post-2002 }\end{array}$ & $\begin{array}{c}\text { ECIP } \\
\text { UESC/ESPC }\end{array}$ & $\begin{array}{l}\text { Space near building } \\
\text { for heat exchange } \\
\text { wells or loop. }\end{array}$ & $\begin{array}{l}\text { Fort Drum buildings are } \\
\text { typical Army buildings, } \\
\text { and correlate to } \\
\text { prototypes analyzed. No } \\
\text { oil or electric furnaces } \\
\text { are used for heating. }\end{array}$ & $\begin{array}{l}\text { Find buildings with } \\
\text { available space nearby } \\
\text { and compare to results. }\end{array}$ \\
\hline \multirow{3}{*}{ 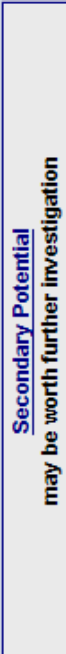 } & $\begin{array}{l}\text { Conversion of } \\
\text { Retired Coal } \\
\text { Plant to } \\
\text { Biomass } \\
\text { Energy Plant }\end{array}$ & $38 \mathrm{MW}$ & 2012 & $\begin{array}{c}\text { According to } \\
\text { development } \\
\text { company, power } \\
\text { could be supplied at } \\
\text { Fort Drum's current } \\
\text { costs, averaged over } \\
\text { the life of the plant. }\end{array}$ & IPP & $\begin{array}{l}\text { Retired coal plant on- } \\
\text { site can be retrofitted } \\
\text { for use as a biomass } \\
\text { plant by a third party. }\end{array}$ & $\begin{array}{l}500,000 \text { tons/year of } \\
\text { wood chip waste is } \\
\text { available in the area. } \\
\text { Development company } \\
\text { can sell all generated } \\
\text { power through a long- } \\
\text { term contract. }\end{array}$ & $\begin{array}{l}\text { Proceed with verification } \\
\text { of assumptions and value } \\
\text { to Army, and with the } \\
\text { investigation into legal } \\
\text { issues. }\end{array}$ \\
\hline & $\begin{array}{l}\text { Municipal } \\
\text { Waste-to- } \\
\text { Energy Plant } \\
\text { using } \\
\text { Combustion } \\
\text { Technology }\end{array}$ & $\begin{array}{l}4 \text { MW or } 15 \mathrm{MW} \\
\text { (depending on } \\
\text { sources of } \\
\text { waste) }\end{array}$ & 2012 & $\begin{array}{c}\text { ECIP scenario: } 1.5 \text { or } \\
2.2 \text { SIR, } 9.5 \text { or } 6.3 \\
\text { year payback at } \\
8.74 \phi / \mathrm{kWh} \\
\text { IPP scenario: } 11.1 \% \\
\text { or } 16.7 \% \text { IRR at } \\
10 \varnothing / \mathrm{kWh}\end{array}$ & $\begin{array}{l}\text { ECIP } \\
\text { IPP }\end{array}$ & $\begin{array}{l}\text { A site near major } \\
\text { roads, a utility } \\
\text { substation, water, } \\
\text { sewage, and an } \\
\text { appropriate industrial } \\
\text { infrastructure, plus } \\
\text { feedstock storage } \\
\text { space. }\end{array}$ & $\begin{array}{l}\text { Waste is available to } \\
\text { supply an economic } \\
\text { project, but importing } \\
\text { MSW on site at Fort Drum } \\
\text { requires more regulatory } \\
\text { review. }\end{array}$ & $\begin{array}{l}\text { If the political and } \\
\text { regulatory situation } \\
\text { allows, verify waste } \\
\text { availability and costs, and } \\
\text { identify potential plant } \\
\text { locations. }\end{array}$ \\
\hline & \begin{tabular}{|} 
Large-Scale \\
Wind Turbines
\end{tabular} & $\begin{array}{c}1.5 \mathrm{MW} \text { installed } \\
\text { capacity, } 26 \% \text { net } \\
\text { capacity factor } \\
\text { generating } 3,461 \\
\text { MWh/yr }\end{array}$ & 2012 & $\begin{array}{l}\text { ECIP scenario: } 0.57 \\
\text { SIR, } 24.6 \text { year } \\
\text { payback at } 7.54 € / \mathrm{kWh} \\
\text { IPP scenario: } 10 \% \\
\text { IRR at } 14.71 € / \mathrm{kWh}\end{array}$ & $\begin{array}{l}\text { ECIP } \\
\text { IPP }\end{array}$ & $\begin{array}{l}\text { Within } 1 \text { mile of } \\
\text { transmission line. } \\
\text { Avoid airport and } \\
\text { radar interference. }\end{array}$ & $\begin{array}{l}\text { Project area will not } \\
\text { present mission conflicts } \\
\text { and will be close enough } \\
\text { to transmission for } \\
\text { interconnection. }\end{array}$ & $\begin{array}{l}\text { If incentives become } \\
\text { available or capital costs } \\
\text { decrease, and interest in } \\
\text { large-scale turbines } \\
\text { returns, the feasibility of a } \\
\text { large-scale wind project } \\
\text { should be reevaluated. }\end{array}$ \\
\hline
\end{tabular}

ECIP = Energy Conservation Investment Program

SIR = savings-to-investment ratio

IPP = independent power producer

UESC = Utility Energy Services Contract

ESPC $=$ Energy Savings Performance Contract 


\section{Table of Contents}

Executive Summary ............................................................................................................... iii

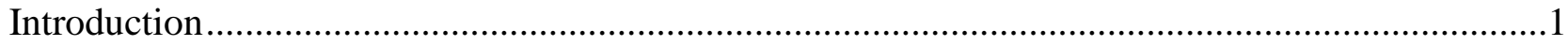

Overview of Federal and DoD Renewable Requirements .............................................................

Analysis of Renewables at Fort Drum .....................................................................................

Approach for Identifying, Analyzing, and Implementing Renewable Energy Projects .........5

Importance of Financing Mechanisms for Project Feasibility .................................................6

The Political and Economic Environment for Renewables at Fort Drum ................................

Fort Drum Energy Characterization...........................................................................

State Incentives for Renewable Project Development...................................................

Federal Incentives for Renewable Project Development..............................................7

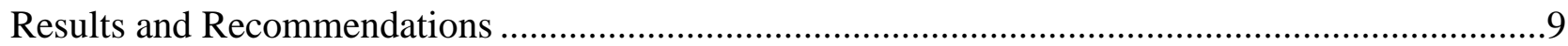

Ground Source Heat Pump Findings and Recommendations................................................9

Biomass Findings and Recommendations ……………………………………………….....11

Wind Energy Findings and Recommendations.....................................................................12

Solar Energy Findings and Recommendations ....................................................................13

Waste-to-Energy Findings and Recommendations..............................................................13

Geothermal Power Plant Findings and Recommendations.....................................................15

Appendix A: Business Case Analysis Approach ..................................................................... A-1

Appendix B: Analysis of Biomass and Waste-to-Energy Opportunities..........................................

Appendix C: Analysis of Geothermal Power Plant Opportunities .....................................................

Appendix D: Analysis of Ground Source Heat Pump Opportunities ........................................... D-1

Appendix E: Analysis of Solar Opportunities …………………………………………............. E-1

Appendix F: Analysis of Wind Opportunities ...........................................................................F-1 


\section{Figures}

Figure A-1: FATE2-P Methodology............................................................................ A-6

Figure C-1: Estimated Temperature at 4 km Depth for Eastern United States........................ C-3

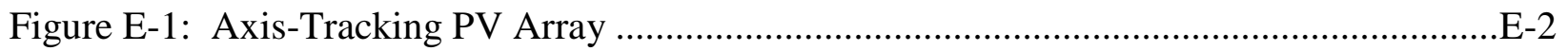

Figure E-2: Solar Insolation Levels (NREL 2008) ............................................................

Figure E-3: Average Daily Insolation at Fort Drum ...........................................................

Figure F-1: New York Wind Resource Map......................................................................... 


\section{Tables}

Table 1: Summary of Promising Renewable Energy Projects at Fort Drum ............................... v

Table 2: Legislated Renewable Energy Targets for DoD ..................................................... 3

Table 3: Summary of Fort Drum Renewable Energy Opportunities ........................................ 10

Table 4: Simple Paybacks for pre-2002 Constructed Buildings ............................................... 9

Table 5: Economic Assessment of Wind Power................................................................. 12

Table 6: Economic Results for Solar Technologies........................................................... 14

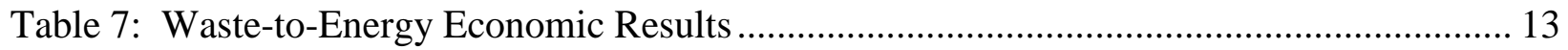

Table 8: Geothermal Economic Results .................................................................................. 15

Table A-1: MACRS Depreciation Rates for Renewable Energy Projects............................... A-3

Table A-2: Discount Rate Assumptions in the ECIP Model ................................................. A-5

Table B-1: Crops and Biomass Production near Fort Drum............................................... B-5

Table B-2: Waste near Fort Drum ............................................................................. B-11

Table B-3: Economic Assumptions, constant \$2010 ....................................................... B-14

Table B-4: Site and Regional MSW Waste-to-Energy Results ........................................... B-15

Table C-1: Performance, Cost, and Economic Characteristics................................................ C-5

Table C-2: Performance, Cost, and Economic Characteristics.............................................. C-5

Table D-1: Building Groups Analyzed in FEDS for GSHPs............................................. D-3

Table D-2: Buildings Analyzed in FEDS for GSHPs* ................................................... D-4

Table D-3: Simple Payback Period for Building Groups Analyzed in FEDS for GSHPs........ D-7

Table D-4: GSHP Opportunities Using ECIP Funding for Post-2002 Constructed Buildings... D-8

Table D-5. Characteristics of Modeled Systems............................................................ D-9

Table E-1: Monthly Averaged Insolation Incident on a South-Facing Tilted Surface at Fort

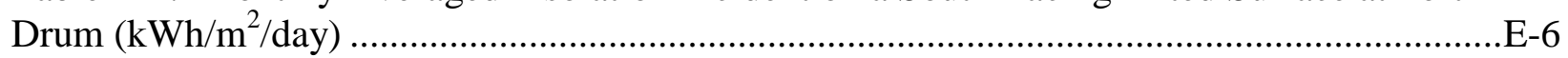

Table E-2: Roof-Integrated Membrane PV Analysis at Fort Drum..........................................E-8

Table E-3: Solar Electric Production by System Type at Fort Drum ....................................... E-8

Table E-4: Economic Results for Solar Technologies at Fort Drum ......................................... E-9

Table F-1: Classes of Wind Power Density at 50 Meters ....................................................F-3

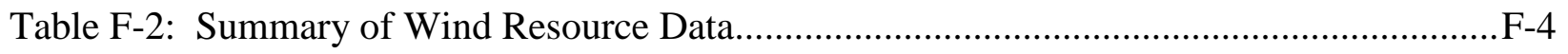

Table F-3: Performance, Cost, and Economic Characteristics ...............................................F-6

Table F-4: Economic Assessment of Wind Power ..............................................................F-7 


\section{Introduction}

Pacific Northwest National Laboratory (PNNL) has been directed by the U.S. Army Installation Management Command (IMCOM) to conduct detailed analyses of the potential for electricity generation at selected U.S. Army installations. The goal of the analyses is to identify economically feasible opportunities for generation of electricity from renewable resourcesgeneration that is significant enough to warrant connection to the grid and/or to contribute in a meaningful way to the aggressive renewable energy goals of the Army and the Department of Defense (DoD).

In 2005, PNNL led a study to identify utility-scale electricity generation opportunities at DoD installations. That study focused on solar, wind, and geothermal. A limited number of attractive large-scale commercial opportunities were identified, and their implementation is now being pursued. The study also identified a number of potential smaller opportunities that needed to be investigated further before project implementation decisions could be made.

This analysis of opportunities at Fort Drum is one of a suite of analyses being conducted at Army installations as follow-on to the 2005 study. The goal is to revisit potential renewable opportunities and focus on projects with a size of at least $1 \mathrm{MW}$, updating the analysis for changes in economics, incentives, knowledge about the available renewable resource, and other factors. In addition, IMCOM has directed PNNL to evaluate the potential for biomass, waste-toenergy, and retrofitting heating and cooling systems in existing buildings with ground source heat pumps (GSHPs). Retrofitting with GSHPs is obviously not an electricity generation opportunity, but it is an opportunity for significant energy savings and replacement of fossil fuels across the DoD. As part of the analysis, IMCOM has directed PNNL to lay out the steps necessary to implement the project opportunities that are identified.

The overall findings of this analysis are summarized in the main body of the report. The business case approach that underlies the analysis of each renewable technology is documented in Appendix A. Appendix B describes the analysis conducted on biomass and waste-to-energy technologies. Appendix C describes the geothermal analysis; Appendix D, the GSHP analysis; Appendix E, the solar analysis; and Appendix F, the wind energy analysis. 


\section{Overview of Federal and DoD Renewable Requirements}

The Army needs to satisfy multiple goals and constraints while securing its energy suppliesfocusing on procurement of the lowest-cost energy that meets high reliability standards and minimum vulnerability to interruption from natural or intentional causes. Overlaid on this challenge is the need to comply with a series of somewhat contradictory statutes and policies, as laid out in Table 2. These include:

Energy Policy Act (EPAct) Section 203. This law mandates the minimum contribution of renewable electricity to an installation's total electricity consumption. The target fractions are 3\% for FY 2007 through FY 2009, 5\% through FY 2012, and not less than 7.5\% beginning in FY 2013.

Executive Order (EO) 13423. The Executive Order reiterates the EPAct goals; however, it uses a different basis than EPAct for measuring and crediting progress. For example, renewable thermal energy counts toward the renewable goal.

National Defense Authorization Act (NDAA). The NDAA codifies DoD's voluntary goal of $25 \%$ by 2025 , but does not include any interim targets. Renewable thermal energy counts toward the renewable goal.

Energy Independence and Security Act (EISA). EISA established two additional renewable goals for new buildings and retrofits. One requires $30 \%$ of domestic hot water to be supplied from solar energy, and the other requires all fossil fuels used in buildings to be displaced by 2030. This is not a power generation goal like the others, but is important to note.

Table 2: Legislated Renewable Energy Targets for DoD

\begin{tabular}{|c|c|c|c|c|}
\hline & $\begin{array}{c}\text { EPAct Section } \\
203\end{array}$ & $\begin{array}{c}\text { Executive Order } \\
13423\end{array}$ & $\begin{array}{c}\text { National Defense } \\
\text { Authorization } \\
\text { Act }\end{array}$ & $\begin{array}{c}\text { Energy } \\
\text { Independence } \\
\text { and Security Act }\end{array}$ \\
\hline Target / Goal & $\begin{array}{l}\text { Increasing targets } \\
\text { reaching } 7.5 \% \text { of } \\
\text { electric energy } \\
\text { from renewables }\end{array}$ & $\begin{array}{l}\text { 7.5\% of electric } \\
\text { energy from } \\
\text { renewables; } 50 \% \\
\text { from new (post- } \\
\text { 1998) sources }\end{array}$ & $\begin{array}{l}\text { Equivalent of } \\
25 \% \text { of electric } \\
\text { energy from } \\
\text { renewables }\end{array}$ & $\begin{array}{l}30 \% \text { of hot water } \\
\text { demand from } \\
\text { solar }\end{array}$ \\
\hline Target Dates & 2013 & 2013 & 2025 & $\begin{array}{c}\text { All new } \\
\text { construction / } \\
\text { major renovations }\end{array}$ \\
\hline Mandatory? & Yes & Yes & No & Yes \\
\hline $\begin{array}{l}\text { Considers thermal } \\
\text { energy "renewable"? }\end{array}$ & No & Yes & Yes & N/A \\
\hline
\end{tabular}

This assessment is primarily for renewable energy provision and retrofit applications in existing buildings. Accordingly, potential in new building construction is mentioned only in passing. The Department of Energy (DOE) is responsible for developing guidance for EPAct and EO 13423. DOE's guidelines for EO compliance, unlike EPAct, allow credit for renewable energy that reduces electricity use from thermal sources; however, it adds a requirement that at least 
$50 \%$ of renewable energy must come from "new” resources: those put into service after January 1, 1999.

Congress did not provide a definition of "renewable" in the NDAA language, and DOE is not responsible for establishing DoD or Army policies to achieve the goals in the NDAA. The current Army energy strategy and associated draft renewable policy takes an expansive view of renewables that encompasses thermal energy from renewable sources. As a result, the Army needs to proceed in a way that makes sense for the Army in a good faith effort to satisfy Congressional, Administration, and Pentagon mandates and directives. The expectation is that the Army will meet the stricter definitions of EPAct on its way to meeting the much higher renewable goals of the NDAA. 


\section{Analysis of Renewables at Fort Drum}

PNNL's renewable energy analysis includes a preliminary assessment based on readily available information sources, a site visit to present the preliminary findings and gather additional information, and a concluding assessment, which is documented in this report.

The site visit to Fort Drum took place on May 4 and 5, 2010 with Alice Orrell, Scott Brown, and Amy Solana attending for PNNL. Fort Drum personnel at the briefing included Steven Rowley (Energy Manager), Mike Richardson (Community Planner), and Jim Corriveau (Director of Public Works). PNNL representatives also met with Walker Heap, Fort Drum's National Environmental Policy Act (NEPA) biologist.

\section{Approach for Identifying, Analyzing, and Implementing Renewable Energy Projects}

Renewable energy resources are unlike conventional resources because the "fuel" is essentially free. However, harnessing this free resource requires substantial investment in resource exploration, characterization, and collection; project development; and ongoing maintenance and operation. A renewable resource is like purchasing a new car with a lifetime of fuel as part of the purchase agreement. First costs are much higher, but total cost may be (should be) lower over the long run.

Economic development of renewable energy depends upon:

- Access to a renewable resource,

- Development costs, and

- Financing that is economically attractive and allowed by Federal and DoD regulations.

Each of these is critically important.

Obviously, a renewable resource has to be available and accessible to be developed. The best resources are those with the greatest potential for displacing conventional fuels or power supplies. Development cost, however, is the great equalizer, and a project based upon an excellent resource located many miles away may be inferior to a project based upon a lesser resource nearby. For example, an excellent wind resource far from an adequate transmission line may be less attractive than an inferior resource adjacent to a transmission line. Similarly, waste resources that could be used in a central plant may not be economic, even if they are "free," if the transportation, handling, and storage costs are greater than the cost of continued use of conventional heating fuels.

Development costs are relatively comparable for similar size projects, irrespective of resource quality. This is why the quality of the resource is so important-namely for the same investment, you get more out of a high quality resource than a lower quality one. But, development costs also include access to transmission capacity for shipping power to users, or alternatively, access to a retail customer. This is a critical difference because power shipped over transmission lines has to compete with the prevailing wholesale price for power from conventional resources. Typically, renewables are not competitive in these markets, unless a buyer specifically demands renewable power. On the other hand, if the power can be used on 
site to displace power purchased from the local utility, it competes against that customer's retail power price or utility rate. Because retail power prices include costs for transmission, distribution, and administrative costs, they are higher than wholesale power prices and make competing renewable projects more attractive economically.

It is important that economic analyses of renewable energy opportunities use realistic data on avoided energy costs, project costs, and available incentive funds, if any. A common analytic mistake is the use of average cost per $\mathrm{kWh}$ - the so-called "blended" rate. Using the blended rate will lead to inaccurate results when the renewable resource is intermittent (like wind and solar) because intermittent resources cannot be guaranteed to reduce peak demand. Even nonintermittent resources may not result in reduced peak demand because of periodic maintenance shutdowns and unscheduled outages. The economic analyses in this report use only the energy component of the power bill ("marginal rate") to evaluate intermittent resources, which is admittedly conservative. The blended rate is used for economic analysis of base-load resources.

Additionally, the installation's utility may impose a standby or other fee in the face of a major on-site generation project that needs to be reflected in the project's cost calculation. The analyses conducted here make no assumptions regarding standby charges because those are typically assessed on a project-by-project basis.

The economic analyses in this report used two perspectives: Energy Conservation Investment Program (ECIP) funding and third-party financing. Under the latter arrangement, power is sold through a contract that is commonly called a power purchase agreement (PPA). This analysis assumed an internal rate of return (IRR) of $10 \%$ is the minimum required to attract a developer. The ECIP analyses assumed projects were not cost-effective if the savings-to-investment ratio (SIR) was less than 1.0. These two options are the lowest-cost among all the options typically available to Army customers.

\section{Importance of Financing Mechanisms for Project Feasibility}

Financing is a critical determinant of development costs because the high first costs are sensitive to financial factors such as incentive payments, tax breaks, and interest rates. Incentive payments and tax breaks reduce first costs, lowering both the overall project cost and interest costs. Because financing is so critical, project economics (payback rates, life-cycle costs, etc.) constitute the best initial screen for project potential. That screen needs to reflect various financing alternatives, which in turn, helps energy managers decide on the best project development approach.

This study focuses on large projects on the premise that if a good renewable resource exists at a site, it should be developed to its maximum potential. Projects smaller than $1 \mathrm{MW}$ are not analyzed except for special cases. The large projects analyzed typically exceed any realistic expectation for appropriated funding, so the assessments also consider commercial (third-party) development of projects. Besides funding limitations, there are other reasons that these large projects should be implemented by third-party investors - under current DoD philosophy, resource development is not a core DoD mission and should be left to the private sector. In addition, private developers can take advantage of tax credits, and they value renewable energy credits (RECs) more highly than the Army does. As a result, letting the developers claim tax 
credits and retain RECs, if available, will reduce the cost of energy to the installation if the developer is selling power from the project to the site.

\section{The Political and Economic Environment for Renewables at Fort Drum Fort Drum Energy Characterization}

Fort Drum is provided electricity from Constellation New Energy (CNE) and electrical transmission from National Grid (NG). The site consumed a total of 131,748 MWh in FY 2009, with a maximum monthly on-peak demand of 23.4 MW in August, and a maximum off-peak demand of 19.5 MW in January. Average on-peak demand was 19.5 MW, and average off-peak demand was 17.9 MW. The total FY 2009 bill was \$13.0 million.

The blended and marginal rates are combinations of CNE and NG charges. The blended rate was calculated to be $8.74 \$ / \mathrm{kWh}$, and the marginal rate was calculated to be $7.54 \$ / \mathrm{kWh}$. The blended rate was used for base-load renewable energy resources, which are not intermittent. These resources include biomass, waste-to-energy (WTE), and geothermal. Solar and wind are intermittent resources, so will not save demand costs; therefore, the marginal rate was applied to these resources.

\section{State Incentives for Renewable Project Development}

State incentives for renewable energy in New York include a green building tax credit for commercial entities, a property tax exemption for solar and wind, a small wind and photovoltaic (PV) rebate, and a renewable portfolio standard (RPS). These incentives are explained in detail in Appendix A.

\section{Federal Incentives for Renewable Project Development}

Federal incentives for renewable energy include investment tax credits for corporations, significantly accelerated depreciation of equipment, and production tax credits. A $30 \%$ tax credit is available for PV projects, and $10 \%$ for geothermal and biomass electricity projects, with no incentive limits. The credits may be taken on equipment placed in service prior to January 1 , 2017. Wind is not eligible for the business energy tax credit. The tax basis for depreciation must be reduced by the amount of any Federal subsidy used in the financing of the eligible equipment.

Depreciation for most renewable energy equipment qualifies for significantly accelerated depreciation. For solar, wind, and geothermal, the modified accelerated cost recovery system (MACRS) provides for 5-year recovery of the cost of equipment. The 5-year recovery period does not apply to biomass or WTE equipment.

The renewable energy production tax credit (PTC), originally established in 1992, provides a tax credit for each kilowatt-hour of electricity produced. The PTC is $2.1 \mathrm{c} / \mathrm{kWh}$ for wind, geothermal, and closed-loop biomass (biomass that is grown with the sole purpose of being used to generate energy) and can be taken for 10 years. The PTC is $1.1 \mathrm{c} / \mathrm{kWh}$ for electricity produced from open-loop biomass and municipal solid waste (MSW) resources and can be taken for 5 years. Solar electricity generation has been excluded for equipment placed in service after December 2005. The PTC has been allowed to lapse and has then been renewed several times. 
Available tax incentives reduce the first-year costs of qualified renewable projects. The lower first cost also reduces the amount of money that must be borrowed to develop a project and thus, the associated interest and carrying costs. The combination reduces the delivered cost of power if developed by a private party with a tax obligation. Government-owned projects do not benefit from tax-based incentives. All of the PPA analyses conducted in this report assume that the PTC and other tax credits will be available when the equipment is placed in service. 


\section{Results and Recommendations}

A summary of analysis results is presented in Table 3, broken down into economic (green), marginal (yellow), or uneconomic (red) projects. The underlying analyses and recommendations for each of these technologies and potential projects are provided in the following subsections.

\section{Ground Source Heat Pump Findings and Recommendations}

The cost-effectiveness of retrofitting existing heating, ventilating, and air conditioning (HVAC) systems with GSHPs on Fort Drum was evaluated using the Facility Energy Decision System (FEDS) building energy modeling program. FEDS analyzed open-loop, horizontal closed-loop, and vertical closed-loop GSHPs for generic buildings to represent post-2002 construction and actual buildings constructed on Fort Drum prior to 2002, using data from a 2002 PNNL datagathering trip. Fort Drum does not have an ideal climate for GSHPs because of the dominant heating season, but these results show there are some opportunities for retrofits.

GSHPs were only found to be cost-effective for a few building groups that were constructed before 2002. In general, buildings need to be air-conditioned to have cost-effective GSHP projects, and not all buildings in Fort Drum's cool climate have air conditioning. Open-loop systems were found to be the most cost-effective, followed by horizontal and then vertical. Projects were identified for buildings with propane and natural gas. All of the cost-effective GSHP projects were found in buildings that are cooled with electric package units, as shown in Table 4.

Table 3: Simple Paybacks for pre-2002 Constructed Buildings

\begin{tabular}{||l|c|c|c|c|c|c|c||}
\hline \multirow{2}{*}{ Description* } & \multirow{2}{*}{\begin{tabular}{c}
\multirow{2}{*}{ Group } \\
ID
\end{tabular}} & \multicolumn{2}{c|}{ UESC/ESPC Financing } & \multicolumn{4}{c||}{ ECIP Financing } \\
\cline { 5 - 8 } & Open** & Horz $\dagger$ & Vert $\dagger$ & Open & Horz & Vert \\
\hline $\begin{array}{l}\text { Medium/Large World War II } \\
\text { Administration }\end{array}$ & $10 \mathrm{~b}$ & 6.4 & 16.0 & - & 6.1 & 13.6 & 16.2 \\
\hline Large Mid-aged Administration & $10 \mathrm{e}$ & - & - & - & 10.5 & - & - \\
\hline Medical, Dental, Veterinarian & 21 & - & - & - & 11.1 & - & - \\
\hline
\end{tabular}

* Building groups with no economically feasible projects are not included in this list

** Open-loop GSHP

$†$ Horizontal closed-loop GSHP

†† Vertical closed-loop GSHP

Open-loop GSHPs were analyzed despite Fort Drum's concern about contamination of groundwater resulting from the direct heat exchange and heat exchanger maintenance requirements. These results are provided in case Fort Drum can consider this option in the future, and to show that they are, in fact, the most cost-effective GSHP technology. 
Table 4: Summary of Fort Drum Renewable Energy Opportunities

\begin{tabular}{|c|c|c|c|c|c|c|c|c|}
\hline & \begin{tabular}{|c|} 
Renewable \\
Resource and \\
Technology \\
\end{tabular} & $\begin{array}{c}\text { Resource } \\
\text { Estimate }\end{array}$ & $\begin{array}{l}\text { Earliest } \\
\text { Output }\end{array}$ & Figures of Merit & $\begin{array}{c}\text { Financing } \\
\text { Mechanisms } \\
\text { Evaluated }\end{array}$ & $\begin{array}{c}\text { Location } \\
\text { Requirements }\end{array}$ & Key Assumptions & $\begin{array}{l}\text { Next Steps / } \\
\text { Comments }\end{array}$ \\
\hline 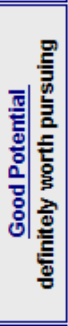 & \begin{tabular}{|} 
Ground Source \\
Heat Pump \\
(Thermal \\
Energy)
\end{tabular} & TBD & 2011 & \begin{tabular}{|} 
ECIP scenario: $6.1-$ \\
16.2 year payback for \\
pre-2002 \\
construction, $3.1-14.1$ \\
years for post-2002 \\
UESC/ESPC \\
scenario: $6.4-16.0$ \\
year payback for pre- \\
2002 construction, 8.2 \\
years for post-2002
\end{tabular} & $\begin{array}{c}\text { ECIP } \\
\text { UESC/ESPC }\end{array}$ & $\begin{array}{l}\text { Space near building } \\
\text { for heat exchange } \\
\text { wells or loop. }\end{array}$ & $\begin{array}{l}\text { Fort Drum buildings are } \\
\text { typical Army buildings, } \\
\text { and correlate to } \\
\text { prototypes analyzed. No } \\
\text { oil or electric furnaces } \\
\text { are used for heating. }\end{array}$ & $\begin{array}{l}\text { Find buildings with } \\
\text { available space nearby } \\
\text { and compare to results. }\end{array}$ \\
\hline \multirow{3}{*}{ 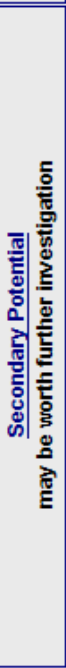 } & \begin{tabular}{|c|} 
Conversion of \\
Retired Coal \\
Plant to \\
Biomass \\
Energy Plant
\end{tabular} & $38 \mathrm{MW}$ & 2012 & $\begin{array}{l}\text { According to } \\
\text { development } \\
\text { company, power } \\
\text { could be supplied at } \\
\text { Fort Drum's current } \\
\text { costs, averaged over } \\
\text { the life of the plant. }\end{array}$ & IPP & $\begin{array}{l}\text { Retired coal plant on- } \\
\text { site can be retrofitted } \\
\text { for use as a biomass } \\
\text { plant by a third party. }\end{array}$ & $\begin{array}{l}500,000 \text { tons/year of } \\
\text { wood chip waste is } \\
\text { available in the area. } \\
\text { Development company } \\
\text { can sell all generated } \\
\text { power through a long- } \\
\text { term contract. }\end{array}$ & $\begin{array}{l}\text { Proceed with verification } \\
\text { of assumptions and value } \\
\text { to Army, and with the } \\
\text { investigation into legal } \\
\text { issues. }\end{array}$ \\
\hline & $\begin{array}{l}\text { Municipal } \\
\text { Waste-to- } \\
\text { Energy Plant } \\
\text { using } \\
\text { Combustion } \\
\text { Technology }\end{array}$ & $\begin{array}{c}4 \text { MW or } 15 \mathrm{MW} \\
\text { (depending on } \\
\text { sources of } \\
\text { waste) }\end{array}$ & 2012 & $\begin{array}{c}\text { ECIP scenario: } 1.5 \text { or } \\
2.2 \text { SIR, } 9.5 \text { or } 6.3 \\
\text { year payback at } \\
8.74 \varnothing / \mathrm{kWh} \\
\text { IPP scenario: } 11.1 \% \\
\text { or } 16.7 \% \text { IRR at } \\
10 \varnothing / \mathrm{kWh}\end{array}$ & $\begin{array}{l}\text { ECIP } \\
\text { IPP }\end{array}$ & $\begin{array}{l}\text { A site near major } \\
\text { roads, a utility } \\
\text { substation, water, } \\
\text { sewage, and an } \\
\text { appropriate industrial } \\
\text { infrastructure, plus } \\
\text { feedstock storage } \\
\text { space. }\end{array}$ & $\begin{array}{l}\text { Waste is available to } \\
\text { supply an economic } \\
\text { project, but importing } \\
\text { MSW on site at Fort Drum } \\
\text { requires more regulatory } \\
\text { review. }\end{array}$ & $\begin{array}{l}\text { If the political and } \\
\text { regulatory situation } \\
\text { allows, verify waste } \\
\text { availability and costs, and } \\
\text { identify potential plant } \\
\text { locations. }\end{array}$ \\
\hline & $\begin{array}{c}\text { Large-Scale } \\
\text { Wind Turbines }\end{array}$ & $\begin{array}{c}1.5 \mathrm{MW} \text { installed } \\
\text { capacity, } 26 \% \text { net } \\
\text { capacity factor } \\
\text { generating } 3,461 \\
\mathrm{MWh} / \mathrm{yr}\end{array}$ & 2012 & $\begin{array}{l}\text { ECIP scenario: } 0.57 \\
\text { SIR, } 24.6 \text { year } \\
\text { payback at } 7.54 \phi / \mathrm{kWh} \\
\text { IPP scenario: } 10 \% \\
\text { IRR at } 14.71 ф / \mathrm{kWh}\end{array}$ & $\begin{array}{l}\text { ECIP } \\
\text { IPP }\end{array}$ & $\begin{array}{l}\text { Within } 1 \text { mile of } \\
\text { transmission line. } \\
\text { Avoid airport and } \\
\text { radar interference. }\end{array}$ & $\begin{array}{l}\text { Project area will not } \\
\text { present mission conflicts } \\
\text { and will be close enough } \\
\text { to transmission for } \\
\text { interconnection. }\end{array}$ & $\begin{array}{l}\text { If incentives become } \\
\text { available or capital costs } \\
\text { decrease, and interest in } \\
\text { large-scale turbines } \\
\text { returns, the feasibility of a } \\
\text { large-scale wind project } \\
\text { should be reevaluated. }\end{array}$ \\
\hline \multirow{4}{*}{ 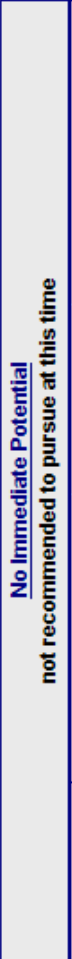 } & $\begin{array}{c}\text { Small-Scale } \\
\text { Wind Turbines }\end{array}$ & $\begin{array}{c}10 \mathrm{~kW} \text { installed } \\
\text { capacity with a } \\
10.1 \% \text { capacity } \\
\text { factor generating } \\
8.9 \mathrm{MWh} / \mathrm{yr}\end{array}$ & 2011 & $\begin{array}{l}\text { ECIP scenario: } 0.18 \\
\text { SIR, } 79.4 \text { year } \\
\text { payback at } 7.54 \text { c/kWh, } \\
0.43 \text { SIR, } 34 \text { year } \\
\text { payback at } 26 \% / \mathrm{kWh} \\
\\
\text { IPP scenario: } 10 \% \\
\text { IRR at } 59-99 \% / \mathrm{kWh} \\
\text { (depending on site) }\end{array}$ & $\begin{array}{l}\text { ECIP } \\
\text { IPP }\end{array}$ & $\begin{array}{l}\text { Small wind turbines } \\
\text { must have a } \\
\text { minimum tower } \\
\text { height to clear tall } \\
\text { trees and other } \\
\text { obstacles. A } \\
\text { minimum hub height } \\
\text { of } 30 \text { m is needed at } \\
\text { the NCO Academy } \\
\text { site. }\end{array}$ & $\begin{array}{l}\text { NYSERDA rebate is } \\
\text { available only for grid- } \\
\text { connected turbines. } \\
\text { Small size may preclude } \\
\text { IPP interest and cost } \\
\text { would require project to } \\
\text { be bundled with other } \\
\text { projects to be eligible for } \\
\text { ECIP funding. }\end{array}$ & $\begin{array}{l}\text { If additional incentives or } \\
\text { a partnership opportunity } \\
\text { to have small-scale wind } \\
\text { as a demonstration } \\
\text { project become available, } \\
\text { the project should be } \\
\text { reevaluated. }\end{array}$ \\
\hline & $\begin{array}{l}\text { Small-Scale, } \\
\text { Off-Grid Solar } \\
\text { Photovoltaics }\end{array}$ & $\begin{array}{c}14 \mathrm{~kW} \text { installed } \\
\text { capacity } \\
\text { generating } 18 \\
\mathrm{MWh} / \mathrm{yr}\end{array}$ & 2011 & $\begin{array}{l}\text { ECIP scenario: } 0.4 \\
\text { SIR, } 34 \text { year payback } \\
\text { at } 26 \phi / \mathrm{kWh} \\
\text { IPP scenario: } 10 \% \\
\text { IRR at } 67.5 \phi / \mathrm{kWh}\end{array}$ & $\begin{array}{l}\text { ECIP } \\
\text { IPP }\end{array}$ & $\begin{array}{l}\text { Adequate unshaded } \\
\text { roof or ground space } \\
\text { available at NCO } \\
\text { Academy. }\end{array}$ & $\begin{array}{l}\text { Small size may preclude } \\
\text { IPP interest and cost } \\
\text { would require project to } \\
\text { be bundled with other } \\
\text { projects to be eligible for } \\
\text { ECIP funding. }\end{array}$ & $\begin{array}{l}\text { Monitor incentives, market } \\
\text { conditions, and } \\
\text { installation's energy } \\
\text { needs so a project can be } \\
\text { reevaluated if conditions } \\
\text { change favorably. }\end{array}$ \\
\hline & $\begin{array}{l}\text { Utility-Grade } \\
\text { Solar Electric } \\
\text { Power Plant }\end{array}$ & $\begin{array}{l}1.0 \mathrm{MW} \text { of roof- } \\
\text { integrated PV } \\
\text { generating } 1,205 \\
\text { MWh annually; } \\
\text { potentially more } \\
\text { generation from } \\
1.0 \mathrm{MW} \text { ground- } \\
\text { mounted PV }\end{array}$ & 2012 & $\begin{array}{l}\text { ECIP scenario: } 0.1 \text { - } \\
0.2 \text { SIR, } 76-95 \text { year } \\
\text { payback at } 7.54 \varnothing / \mathrm{kWh} \\
\text { IPP scenario: } 10 \% \\
\text { IRR at } 36.8- \\
45.5 \varnothing / \mathrm{kWh} \\
\\
\text { (depending on } \\
\text { technology) }\end{array}$ & $\begin{array}{l}\text { ECIP } \\
\text { IPP }\end{array}$ & $\begin{array}{l}\text { Rooftops, especially } \\
\text { where replacing } \\
\text { roofs. Also open } \\
\text { ground area near } \\
\text { high-voltage } \\
\text { transmission lines, } \\
\text { and away from } \\
\text { obstruction by } \\
\text { shadows or danger of } \\
\text { vandalism. }\end{array}$ & $\begin{array}{l}\text { The solar resource is not } \\
\text { great enough for } \\
\text { economic electricity } \\
\text { generation. }\end{array}$ & $\begin{array}{l}\text { If additional incentives } \\
\text { become available or there } \\
\text { is a rate increase, the } \\
\text { feasibility of a large solar } \\
\text { project should be } \\
\text { reevaluated. }\end{array}$ \\
\hline & $\begin{array}{c}\text { High } \\
\text { Temperature } \\
\text { Geothermal } \\
\text { Generation } \\
\text { Plant }\end{array}$ & $\begin{array}{c}10 \text { MW capacity } \\
\text { generating } \\
84,154 \mathrm{MWh} / \mathrm{yr}\end{array}$ & N/A & $\begin{array}{l}\text { ECIP scenario: } 0.37 \\
\text { SIR, } 37 \text { year payback } \\
\text { at } 8.65 \phi / \mathrm{kWh} \\
\text { IPP scenario: } 10 \% \\
\text { IRR at } 25.3 \phi / \mathrm{kWh}\end{array}$ & $\begin{array}{l}\text { ECIP } \\
\text { IPP }\end{array}$ & $\begin{array}{l}\text { Must drill to a depth of } \\
8 \mathrm{~km} \text { to reach the } \\
\text { temperature required. }\end{array}$ & $\begin{array}{l}\text { No known high } \\
\text { temperature resource at } \\
\text { the standard drill depth of } \\
3 \mathrm{~km} \text {. }\end{array}$ & $\begin{array}{l}\text { No action is } \\
\text { recommended. }\end{array}$ \\
\hline
\end{tabular}

For post-2002 construction, GSHPs were found to be cost-effective in a number of typical building types. With ECIP funding, open-loop and horizontal closed-loop systems were found to 
be cost-effective most often. Overall, simple payback periods range from 3.1 to 14.1 years for barracks and 5.1 to 14.6 years for administration buildings. GSHP projects replacing air-cooled chillers tend to have much better economics than projects in buildings with other cooling technologies.

With UESC/ESPC financed projects, the capital cost is increased, so only large barracks currently using air-source heat pumps are cost-effective for open-loop GSHP retrofits. The payback would be 8.2 years. No other financed options are cost-effective at this time.

The building-specific results should be investigated for available land area for heat exchanger wells or loops to determine whether a GSHP is practical to install in each recommended location. The generic results should be compared to buildings constructed after 2002 with available land area. Where there are similarities between the generic and existing buildings, detailed building and surrounding land area information should be collected to pursue project viability.

Detailed results of these analyses are provided in Appendix D.

\section{Biomass Findings and Recommendations}

The availability of mill residue, landfill gas, and wastewater treatment plant sludge is inadequate to consider a large biomass generation project. Other potentially available biomass fuels, including crop residue, animal waste and dedicated biomass crops, do not support economic electricity generation at this time.

Fort Drum has received an unsolicited proposal to provide Fort Drum electricity generated from a woody biomass facility located on land leased from Fort Drum. The proposal requires that the retired coal plant on site be converted to a biomass energy plant. There are a number of concerns with the proposal currently being discussed among Fort Drum, the development company, Defense Energy Support Center, and other involved parties. These concerns include whether the project will provide cost savings to Fort Drum, the length of the requested power purchase agreement, and other logistical and legal issues.

The plant will use approximately 500,000 tons/year of wood chips and generate 38 MW of electricity at a cost roughly the same as what Fort Drum is currently paying, according to the development company. The New York State Energy Research and Development Authority (NYSERDA) has agreed to buy the project's renewable energy credits (RECs) from the development company. The sale of RECs will lower the cost of energy to Fort Drum, and if Fort Drum can then purchase less expensive replacement RECs, the project will get double credit towards EPAct goals for generating renewable power and being located on Federal property.

For now, this proposed biomass project is the only potentially feasible option for biomass and large-scale renewable energy generation at Fort Drum. It is recommended to proceed with the verification of assumptions and investigation into legal issues required for implementation. See Appendix B for more details. 


\section{Wind Energy Findings and Recommendations}

The low to moderate wind resource at Fort Drum and the current cost assumptions result in marginal economics for a large-scale wind energy project at Fort Drum. With a wind speed of $6.44 \mathrm{~m} / \mathrm{s}$ at $100 \mathrm{~m}$, a commercial energy cost of $14.71 \mathrm{\$} / \mathrm{kWh}$ would be required to provide a $10 \%$ IRR. This is double the price Fort Drum is currently paying. Using ECIP funding, the SIR is 0.57, and the payback is almost 25 years, as shown in Table 5.

Table 5: Economic Assessment of Wind Power

\begin{tabular}{|c|c|c|c|}
\hline Financing & \multicolumn{2}{|c|}{ ECIP } & IPP \\
\hline Economic Factor & SIR & $\begin{array}{c}\text { Simple } \\
\text { Payback, } \\
\text { years }\end{array}$ & $\begin{array}{c}\text { Cost of Electricity } \\
\text { at } 10 \% \text { IRR, } \\
\mathbf{c} / \mathbf{k W h}\end{array}$ \\
\hline $\begin{array}{c}\text { On-Site Large } \\
\text { Wind }\end{array}$ & 0.57 & 24.6 & 14.71 \\
\hline $\begin{array}{l}\text { On-Site Small } \\
\text { Wind }\end{array}$ & 0.18 & 79.4 & 59.92 \\
\hline $\begin{array}{l}\text { Remote Small } \\
\text { Wind at NCO } \\
\text { Academy }\end{array}$ & 0.43 & 34.0 & 99.13 \\
\hline
\end{tabular}

Small wind turbines were examined at Fort Drum's request. A 3-MW wind project was under development at Fort Drum in 2004, but did not proceed because of concerns that the project would interfere with Fort Drum's radar operations. Because of this past experience, Fort Drum is currently only interested in small wind projects.

The small wind turbine cases had less economic potential because of the higher per-kW capital costs and lower energy production of small systems. However, a small wind project on site could be used as a demonstration project, for example at the proposed Zero Energy Building. A small wind turbine could offset a portion of the building's energy consumption.

Fort Drum is in discussion with a couple of vertical-axis wind turbine (VAWT) manufacturers who may be willing to donate prototype products because they are in need of demonstration and testing sites. If Fort Drum were to accept a free VAWT, the expectations going into the project would have to be clear. It would have to be agreed that Fort Drum is providing a site for the manufacturer to test its unproven technology. There is concern that if a wind technology is implemented and doesn't work, it will take a long time to turn around public perception about wind at Fort Drum.

Based on the economics, it is not recommended that Fort Drum pursue a small-scale or largescale wind energy project at this time. This analysis is detailed in Appendix F. However, if capital costs were to decrease, more incentives become available, or a demonstration partner were found, Fort Drum should reconsider these projects. Fort Drum may have the chance to 
reevaluate wind project potential with the wind studies it has requested from both the Office of the Assistant Chief of Staff for Installation Management (OASCIM) and New York State Energy Research and Development Authority (NYSERDA).

\section{Waste-to-Energy Findings and Recommendations}

Multiple off-site MSW scenarios showed favorable economics in the initial screening. A detailed economic analysis was conducted for two of the most likely cases so that Fort Drum will have this information available if the regulatory and political situation allows. The results are shown in Table 7.

Table 6: Waste-to-Energy Economic Results

\begin{tabular}{||l|c|c||}
\hline Waste Source & $\begin{array}{c}\text { Jefferson County } \\
\text { Transfer Station }\end{array}$ & $\begin{array}{c}\text { DANC Rodman } \\
\text { Landfill }\end{array}$ \\
\hline Technology & Combustion & Combustion \\
\hline Plant Size & $4.0 \mathrm{MW}$ & $15.0 \mathrm{MW}$ \\
\hline Feedstock Amount & 36,000 tons/yr & 136,200 tons $/ \mathrm{yr}$ \\
\hline Total Plant Cost & $\$ 4,561.3 / \mathrm{kW}$ & $\$ 3,495.5 / \mathrm{kW}$ \\
\hline Capital Cost & $\$ 4,233.2 / \mathrm{kW}$ & $\$ 3,244.1 / \mathrm{kW}$ \\
\hline Sales Tax & $\$ 328.1 / \mathrm{kW}$ & $\$ 251.4 / \mathrm{kW}$ \\
\hline Fixed O\&M Cost & $\$ 186.0 / \mathrm{kW}$ & $\$ 104.8 / \mathrm{kW}$ \\
\hline Variable O\&M Cost & $-1.3 \$ / \mathrm{kWh}$ & $-1.3 \$ / \mathrm{kWh}$ \\
\hline Feedstock Cost & $-\$ 20.50 /$ ton & $-\$ 20.50 /$ ton \\
\hline \hline SIR & 1.5 & 2.2 \\
\hline Simple Payback & $9.5 \mathrm{years}$ & $6.3 \mathrm{years}$ \\
\hline IRR, No Financing & $11.11 \%$ & $16.69 \%$ \\
\hline \hline
\end{tabular}

The first scenario analyzed was the use of waste from the Jefferson County Transfer Station, because of its close proximity to Fort Drum. In the event that DANC is not able to move forward with the planned expansion of the Rodman Landfill and an alternative for waste disposal is needed, a scenario was also analyzed for a WTE plant sized to Fort Drum's current average electric load (15 MW) using waste diverted from the Rodman Landfill. Other waste sources may also be available; if pursued, the first step in WTE plant implementation would be quantifying available MSW and finding suppliers.

Two different technologies were examined for this analysis: gasification and combustion. Gasification is more efficient than combustion, but not as mature or common in commercial operation as combustion. For Fort Drum, scenarios utilizing combustion were more economical. 
Fort Drum should consider these possible scenarios. Potential project locations could be along the state road, which would allow truck access, or in the northern corner of Fort Drum. These locations would minimize impacts to Fort Drum operations and mission. Assuming the plant is third-party owned, Fort Drum would not be responsible for reporting plant emissions under current regulations. Detailed data and results are provided in Appendix B.

\section{Solar Energy Findings and Recommendations}

With current electricity prices and available solar resource, solar electricity did not prove economic. Fort Drum's solar resource was found to be 4.2 to $5.2 \mathrm{kWh}_{\text {solar }} / \mathrm{m}^{2} /$ day, depending on the technology. Ground-mounted fixed-angle photovoltaics (PV), axis-tracking PV, and building-integrated roof-mounted PV were too expensive for the amount of energy that could be produced. Table 6 shows the detailed economic results for the ECIP funding and third-party financing analyses for the PV technologies. See Appendix E for analysis details.

Table 7: Economic Results for Solar Technologies

\begin{tabular}{|l|c|c|c|c|c||}
\hline & $\begin{array}{c}\text { 1-MW } \\
\text { South- } \\
\text { Facing, } \\
\text { Ground- } \\
\text { Mounted, } \\
\text { Latitude- } \\
\text { Tilt Silicon } \\
\text { PV }\end{array}$ & $\begin{array}{c}\text { 1-MW } \\
\text { Ground- } \\
\text { Mounted, } \\
\text { Tracking } \\
\text { Silicon PV }\end{array}$ & $\begin{array}{c}\text { 1-MW } \\
\text { Roof- } \\
\text { Mounted } \\
\text { CdTe } \\
\text { Thin Film } \\
\text { PV }\end{array}$ & $\begin{array}{c}\text { 1-MW } \\
\text { Roof- } \\
\text { Mounted } \\
\text { Silicon } \\
\text { PV }\end{array}$ & $\begin{array}{c}\text { Academy } \\
\text { 14-kW } \\
\text { Latitude } \\
\text { Tilted } \\
\text { Silicon PV } \\
\text { Array }\end{array}$ \\
\hline $\begin{array}{l}\text { Equipment Cost } \\
\text { Assumptions, \$/kW }\end{array}$ & 5,625 & 6,625 & 4,000 & 4,500 & 8,000 \\
\hline SIR & 0.2 & 0.1 & 0.2 & 0.2 & 0.4 \\
\hline Simple Payback, yrs & 92 & 95 & 76 & 86 & 34 \\
\hline $\begin{array}{l}\text { Cost of Electricity at } \\
\text { 10\% IRR, } / \mathbf{k W h}\end{array}$ & 45.5 & 43.6 & 36.8 & 41.5 & $67.5 *$ \\
\hline $\begin{array}{l}\text { Variable Operation } \\
\text { and Maintenance } \\
\text { Costs (O\&M), c/kWh }\end{array}$ & 0.0 & 0.0 & 0.0 & 0.0 & 0.0 \\
\hline $\begin{array}{l}\text { Fixed O\&M Costs, } \\
\text { \$/net kW }\end{array}$ & 20 & 33 & 20 & 20 & 20 \\
\hline $\begin{array}{l}\text { Federal Energy Tax } \\
\text { Credit (a credit worth } \\
\text { a percentage of the } \\
\text { expenditures) }\end{array}$ & $30 \%$ & $30 \%$ & $30 \%$ & $30 \%$ & $30 \%$ \\
\hline
\end{tabular}

In addition to the large-scale PV arrays, this assessment also examined a small-scale PV array for the off-grid Non-Commissioned Officers (NCO) Academy site per Fort Drum's request. The PV array for the NCO Academy could displace electricity produced by two 35-kW propane generators and could possibly have battery storage with it.

Although the economics are unfavorable, there is interest at Fort Drum in solar projects, so Fort Drum should continue to monitor the market conditions affecting solar energy, the incentives available, and the installation's energy needs so a project can be reevaluated in the future if conditions change favorably. 


\section{Geothermal Power Plant Findings and Recommendations}

According to existing data, Fort Drum lacks naturally occurring hot water/steam fields and elevated temperatures at economic depths (less than 3,000 m). To reach the required temperature of at least $212^{\circ} \mathrm{F}\left(100^{\circ} \mathrm{C}\right)$, drilling to a depth of $8,000 \mathrm{~m}$ is required, resulting in high drilling costs. The results of this analysis are presented in Table 8.

Table 8: Geothermal Economic Results

\begin{tabular}{|c|c|c|c||}
\hline $\begin{array}{c}\text { Financing } \\
\text { Scenario }\end{array}$ & \multicolumn{2}{|c|}{ ECIP } & IPP \\
\hline Economic Factor & SIR & $\begin{array}{c}\text { Simple } \\
\text { Payback, } \\
\text { years }\end{array}$ & $\begin{array}{c}\text { Cost of Electricity } \\
\text { at 10\% IRR, } \\
\text { \$/kWh }\end{array}$ \\
\hline $\begin{array}{c}\text { 10 MW } \\
\text { Geothermal } \\
\text { Project }\end{array}$ & 0.37 & 37 & 25.3 \\
\hline \hline
\end{tabular}

Because the geothermal resource is inadequate to support an economic project at Fort Drum, no immediate action should be taken. Considering the geology of the area in which Fort Drum is located, it is unlikely that there will be any changes in resource availability in the near future. Detailed data and results are provided in Appendix C. 


\section{APPENDIX A}

\section{Business Case Analysis Approach}





\section{Appendix A: Business Case Analysis Approach}

\section{Overall Basis for Project Economic Feasibility}

The renewable projects considered in this analysis need to compare favorably against the current commercial price of electricity to be purchased by Fort Drum to be economically feasible. Fort Drum obtains its electricity from Constellation New Energy (CNE) through National Grid (NG).

CNE charges Fort Drum on a fixed-price basis and NG charges Fort Drum for electrical transmission on a time-of-use (TOU) basis. CNE charges Fort Drum 6.3336 $\mathbb{k} / \mathrm{kWh}$, independent of seasonality or time-of-use. The CNE contract began in January 2010 and will conclude in December 2012, at which point it will be re-competed or renewed.

NG charges Fort Drum for electricity transmission as described in the service rate TOU SC-3A. Demand charges include a distribution delivery charge of $\$ 2.70 / \mathrm{kW}_{\text {peak }}$ and a competitive transition charge of $\$ 3.09 / \mathrm{kW}_{\text {peak }}$, for a total demand charge of $\$ 5.79 / \mathrm{kW}_{\text {peak. }}$. Peak demand is defined to be the highest demand measured over any 15-minute interval during the month. NG also charges $\$ 1.02 / \mathrm{RkVA}$. Electricity transmission is charged on a block structure. The first block is defined to be 250 hours multiplied by the peak kilowatt demand for both on- and offpeak periods. On-peak kilowatt-hours are charged $1.636 \$ / k W h$ and off-peak kilowatt-hours are charged $1.271 \mathrm{\&} / \mathrm{kWh}$. On-peak hours are the hours from 0800 to 2200 Monday through Friday, except holidays. Excess kilowatt-hours beyond the first block are not charged. In addition, all kilowatt-hours consumed are charged a Systems Benefit Charge of 0.5562 $\$ / \mathrm{kWh}$, a Transmission Revenue Adjustment Charge that averaged $-0.097 \$ / \mathrm{kWh}$ over FY 2009, and a Customer Service Backout Credit that averaged -0.0058\$/kWh over FY 2009.

The blended and marginal rates are combinations of CNE and NG charges. The blended rate

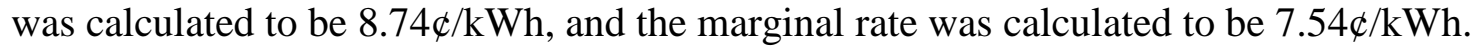

Solar and wind renewable energy resources would displace the direct energy (kWh) charge, or the marginal rate. Geothermal and waste-to-energy need to compare favorably against the average cost (including demand charges), or the blended rate. The ground source heat pump (GSHP) analysis used the detailed time-of-use rate schedule to calculate operational cost savings.

CDE and NG provided Fort Drum with 131,748 MWh in FY 2009, with a maximum monthly on-peak demand of 23.4 MW in August, and a maximum off-peak demand of 19.5 MW in January. Average on-peak demand was $19.5 \mathrm{MW}$, and average off-peak demand was $17.9 \mathrm{MW}$. The total FY 2009 bill was $\$ 13.0$ million.

The Non-Commissioned Officers (NCO) Academy is a remote site powered by two 35-kW propane generators operating at 22\% efficiency. The cost of propane for Fort Drum is $\$ 1.63 /$ gallon, which results in a $\$ 0.26 / \mathrm{kWh}$ cost of energy. Potential solar and wind energy projects at this remote site are compared against this cost of propane-fueled energy.

All but one of the analyses was conducted using the Financial Analysis Tool for Electric Energy Projects (FATE2-P) financial analysis model, described later in this appendix. The analysis for 
GSHPs was conducted using the Federal Energy Decision System (FEDS) model, also described in this appendix.

\section{Analytic Approaches}

In assessing the economic feasibility of renewable energy projects at Fort Drum, Pacific Northwest National Laboratory (PNNL) generally evaluated two business case alternatives, (1) investment by an independent power producer (IPP), and (2) Energy Conservation Investment Program (ECIP) funding. These two funding sources have the best returns on Federal investments among the available alternatives. Two other funding mechanisms were examined when evaluating GSHP projects: (3) the Utility Energy Services Contract (UESC), and (4) the Energy Savings Performance Contract (ESPC).

Under an IPP scenario, an independent power producer will generally fund, construct, and operate a renewable energy facility, selling power into the competitive marketplace and/or directly to the site that hosts the energy project. This scenario is generally economic when the third-party investor can take advantage of substantial Federal and state incentives. The incentives depend on the type of renewable energy generated and may include production tax credits, investment tax credits, substantially accelerated tax depreciation of assets, reductions in sales taxes, and exemption from property tax.

ECIP is one standard DoD approach for making energy efficiency and renewable energy investments using Federally appropriated funding. ECIP investment awards are made based upon savings to investment ratio (SIR) and simple payback criteria. ECIP funding is limited, and is awarded on a competitive basis within the Army-only the most economic projects can be assured funding. The approach used in the analyses follows the Federal life-cycle cost (LCC) methodology and procedures in 10 CFR, Part 436, Subpart A. The LCC calculations are based on the Federal Energy Management Program (FEMP) discount rates and energy price escalation rates updated on April 1, 2009.

The UESC and ESPC are very similar approaches, where a third party invests in an energy project on the Federal facility in return for a share of the energy savings that result. The major difference is that under an UESC, the third party is a utility-generally the utility providing energy to the Federal facility. Under ESPC, the investment party is a non-utility, generally an engineering firm that specializes in energy projects. Under UESC and ESPC, the third party must be repaid out of each year's operational dollars, and the investment must be repaid within the lifetime of the asset. Generally, UESC is more feasible than ESPC because utilities can obtain capital less expensively than can the ESPC contractor. But not all utilities fund UESC projects and the types of projects funded may be limited, opening the door for ESPC. The UESC/ESPC cannot generally capture depreciation or tax incentives that would be afforded an IPP.

\section{Independent Power Producer Assumptions}

In addition to capital and operating costs, project feasibility for the IPP is dependent on Federal and state tax incentives, interest rates, inflation rates, and required rates of return discussed in the following sections. 


\section{Federal Incentives for Renewable Energy}

Federal incentives for renewable energy include investment tax credits for corporations, significantly accelerated depreciation of equipment, and production tax credits. Combining the incentives with attractive market prices can, in certain cases, lead to feasible renewable energy projects.

\section{Tax Credits}

A 30\% business energy tax credit (investment tax credit) is available for photovoltaic and smallscale wind projects; a 10\% credit is available for geothermal and biomass electricity projects (DSIRE 2010a). Large-scale wind, geothermal and biomass electricity generation projects also qualify for production tax credits (JCT 2007), but both can't be taken at the same time. Financial crisis emergency legislation lengthened the investment tax credit period by 8 years to January 1 , 2017 from its previous end of December 31, 2008 (H.R. 1424 2008). There are no incentive limits for solar and geothermal electric.

\section{Depreciation}

Most renewable energy equipment qualifies for significantly accelerated depreciation using the modified accelerated cost recovery system (MACRS). According to 168(e)(3)(B)(vi), most renewable energy production facilities would qualify for 5-year accelerated depreciation (U.S. Treasury 2009a, 26 USC § 168).

Table A-1 provides the depreciation rates used in the model for 5-year property. The rates reflect the use of the 3/4-year convention. The basis is reduced by $50 \%$ of any energy investment tax taken (JCT 2007). The tax basis for depreciation must also be reduced by the amount of any Federal subsidy used in the financing of the eligible equipment (26 USC § 48).

Table A-1: MACRS Depreciation Rates for Renewable Energy Projects

\begin{tabular}{||c|c|c|c|c|c||}
\hline \hline Year 1 & Year 2 & Year 3 & Year 4 & Year 5 & Year 6 \\
\hline $35 \%$ & $26 \%$ & $15.6 \%$ & $11.01 \%$ & $11.01 \%$ & $1.38 \%$ \\
\hline
\end{tabular}

\section{Production Tax Credits}

The renewable energy production tax credit (PTC) provides a per-kWh-produced tax credit for electricity generated. The PTC is $2.1 \mathrm{\$} / \mathrm{kWh}$ in 2009 for wind, geothermal, and closed-loop biomass (biomass that is grown with the sole purpose of being used to generate energy) and can be taken for 10 years. The PTC is $1.1 \mathrm{k} / \mathrm{kWh}$ for electricity produced from open-loop biomass and municipal solid waste resources and can be taken for 5 years (U.S. Treasury 2009b). The PTC for solar electricity generation has been excluded for equipment placed in service after December 2005 (H.R. 6111 2006). The PTC has been allowed to lapse and then been renewed several times. All of the analyses assume it will be available when the equipment is placed in service. 


\section{New York-Specific Incentives and Taxes}

State incentives for renewable energy in New York include a green building tax credit for commercial entities, a property tax exemption for solar and wind, a small wind and PV rebate, and a renewable portfolio standard (RPS).

New York State provides a tax credit for up to \$2 million per building for solar technologies such as photovoltaics (PV) and solar thermal. The entity must work through an architect or engineer to obtain the credits. The building where solar PV is provided must meet all other components for green spacing including energy, indoor air quality, materials, water conservation, and commissioning. The credit cannot be obtained for just adding solar PV to a building (DSIRE 2010b).

New York State also provides a local option for counties and local jurisdictions to exempt renewable energy resources such as solar PV, wind, biomass and others from paying property taxes on the value of the equipment installed. The law is set to expire January 1, 2011 (DSIRE 2010c), but a couple of different legislative bills are currently under review that would extend the exemption to 2015. However, it was not included in this analysis because local jurisdictions may choose to disallow the exemption, and Watertown, New York has chosen to opt out.

The state of New York also has a RPS that requires 30\% of electricity to come from renewable energy resources by 2015. Existing resources are expected to make up approximately 20.7\% of the requirement. New York State Energy Research and Development Authority (NYSERDA) collects funds for the RPS from a surcharge on every kWh sold by investor-owned utilities. The funds allow NYSERDA to offset the costs of renewable installation (DSIRE 2010d).

From these funds, NYSERDA provides a rebate incentive for grid-connected small wind and solar PV systems. The small wind incentive level varies depending on the size of the system, the tower height, and the class of customer (NY State 2004a) and was included accordingly. The incentive is only available for systems installed by an eligible installer and then the incentive must be passed on in full to the customer from the installer. The PV incentive is $\$ 1.75$ per watt up to a maximum of $50 \mathrm{~kW}$ per site electrical meter for a non-residential entity, not to exceed $50 \%$ of the total installed cost (NY State 2004b). Because of the project size limit, the PV incentive was not included in this analysis.

A sales tax of 7.75\% (NYSDTF 2010) was applied where appropriate in this analysis. State corporate income taxes of $7.1 \%$ were applied to renewable project types that required state income taxes to be applied (NYSDTF 1998). A property tax rate of $1.14 \%$ was assumed. The effective property tax rate was $0.73 \%$, because Jefferson County's uniform assessment rate appears to be $64 \%$ (TW 2009).

New York State allows net metering. Net metering allows the customer to sell back to the grid, at customer rates, the excess energy generated by on-site generation sources. The limitations are very restrictive with the exception of $2 \mathrm{MW}$ for wind and solar (DSIRE 2010e). The sale of energy through a net metering program is not included in this analysis because Fort Drum projects are not expected to meet the requirements. 


\section{Other Independent Power Producer Assumptions}

The minimum after-tax internal rate of return (IRR) used in the analysis of IPP opportunities was $10 \%$. The typical after-tax rate of return for most third-party developers is closer to $15 \%$, but there appears to be a suite of renewable energy developers willing to accept a lower return. Both costs and prices were assumed to escalate with an inflation rate of $1.2 \%$.

\section{Energy Conservation Investment Projects}

The assumptions for ECIP are driven by FEMP. Table A-2 lays out the discount rates underlying the model as of April 2009. The real and nominal rates for DOE/FEMP imply a 1.2\% inflation rate. New discount rates were obtained from Rushing and Lippiatt (2009).

Table A-2: Discount Rate Assumptions in the ECIP Model

\begin{tabular}{||r|c|c|c|c|c|c||}
\hline \hline Discount Rate & $\begin{array}{c}\text { DOE } \\
\text { FEMP }\end{array}$ & $\begin{array}{c}\text { OMB 3- } \\
\text { year }\end{array}$ & $\begin{array}{c}\text { OMB 5- } \\
\text { year }\end{array}$ & $\begin{array}{c}\text { OMB 7- } \\
\text { year }\end{array}$ & $\begin{array}{c}\text { OMB 10- } \\
\text { year }\end{array}$ & $\begin{array}{c}\text { OMB 30- } \\
\text { year }\end{array}$ \\
\hline real & $3.0 \%$ & $2.1 \%$ & $2.3 \%$ & $2.4 \%$ & $2.6 \%$ & $2.8 \%$ \\
\hline nominal & $4.2 \%$ & $3.3 \%$ & $3.5 \%$ & $3.6 \%$ & $3.8 \%$ & $4.0 \%$ \\
\hline
\end{tabular}

\section{FATE2-P Model Description}

The FATE2-P (Financial Analysis Tool for Electric Energy Projects) financial analysis model was used to evaluate the feasibility of renewable energy projects at Fort Drum. The spreadsheet model was developed by Princeton Economic Research, Inc. and the National Renewable Energy Laboratory for the U.S. Department of Energy. FATE2-P can be used to develop pro forma financial statements for a utility using a revenue requirements approach or an IPP using the discounted rate of return approach. Both approaches are diagrammed in Figure A-1. Other models produce very similar results given the same inputs. The revenue requirements approach follows a cost-based utility revenue requirements analysis, and the IPP approach uses a marketbased discounted cash flow return. The FATE2-P model has been updated by PNNL to include the Military Construction (MILCON) ECIP Module in addition to the rate of return methodology. The model has been used to model improved technology designs, resource variability, and favorable tax treatment on renewable energy products. The advantage this model has over other models is that it is already suited for handling all of the renewable energy technologies in this study through one model, thus providing results on a comparable basis across all technologies. 

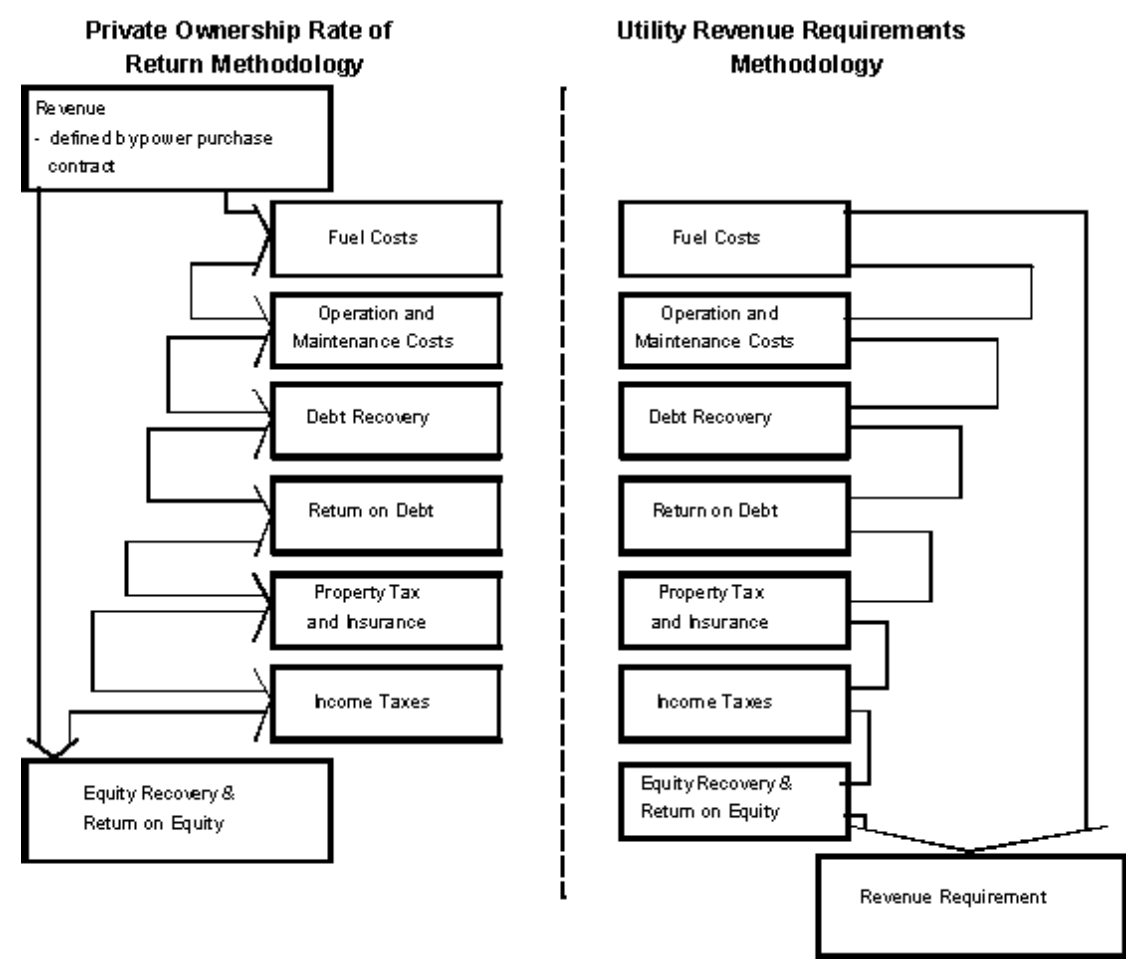

Figure A-1: FATE2-P Methodology

\section{Private Ownership Rate of Return Methodology}

The Private Ownership Rate of Return Module (IPP) develops an annual after-tax cash flow based on the revenues defined in the power purchase contract and costs associated with constructing and operating the generation facility. The goal of this approach is to capture the relevant investment costs after-tax and compare them with the net cash flow from the after-tax investment over time. The model contains sections to capture the relevant costs of construction, including the debt and equity capital accumulation to purchase the investment and the associated payback of debt and equity capital. In addition, the model has sections associated with revenue generation, cash flow, an income statement, and associated statements to calculate tax liabilities to capture after-tax cash flow. The financing section includes several pertinent sections including sources and uses, construction and debt accumulation, reserve funds requirements, debt schedule, amortization of debt fees, and debt service coverage ratios.

$\checkmark$ The Sources and Uses of Funds section shows the allocation of construction funds between components and sources of those funds. Uses of funds include construction cost, AFUDC (allowances for funds used during construction), and underwriters' fees for both debt and equity.

$\checkmark$ The construction and debt accumulation statement is capable of handling a 6-year construction period starting at any date. Any construction draw schedule can be used for 1 to 6 years. An equal percentage draw schedule for each year of any given construction length is the default. 
$\checkmark$ The model contains major maintenance and debt-service reserve funds. Both types of accounts generate interest income that becomes a part of the income statement through a drawn-off interest calculation. The model does not currently calculate a working capital reserve account. Such an account would add interest costs to the cost statement in addition to the interest costs on the capital investment.

$\checkmark$ The debt schedule allows three types of financing: level payment, bullet, and customized. Level payment is customary for projects that have adequate cash flow to satisfy debt coverage payments and are of short duration. Customized is required when certain years fall below the minimums set by the investment banking industry.

$\checkmark$ Cash flow statements can be constructed for up to 30 years of revenue generation plus the 6-year construction time frame.

$\checkmark$ The Revenue Module contains a variable capacity factor that must be filled in by the analyst to capture depletion of the geothermal fields or the capacity of wind or the other renewable energy resources. This section also allows for secondary energy byproduct credits (such as for steam if it has value), and up to six different types of subsidy payments, if available. The model also accepts after-tax production credits, if available, and includes interest on reserves.

$\checkmark$ Cash expenses statements include standard operations and maintenance (O\&M) costs (both fixed and variable), general and administrative (G\&A), insurance, and land fees. There is major maintenance expense along with a reserve fund dedicated to covering the major maintenance when it occurs. Up to two different fuel costs can be entered. There is also an entry for royalty fees associated with geothermal.

$\checkmark$ The earnings statement in this model calculates earnings and taxes based on a tax table. Operating income is calculated by subtracting cash and operating expenses from revenue, as described in the section above. Taxable income is determined by subtracting cash and non-cash expenses such as interest, depreciation, amortization of fees, IDC (interest during construction) and depletion allowances. Taxes paid and tax credits received are netted and after-tax book income is calculated. The net taxes paid become a part of the cash flow.

$\checkmark$ The model includes straight-line and MACRS depreciation approaches, with mid-quarter convention depreciation tables. Straight-line allows for the calculation of book basis value of assets and liabilities, while MACRS allows for the taxable basis of the investment.

$\checkmark$ The model amortizes debt-related fees over 15 years and equity organizational fees over 5 years. Equity tax advice is expensed in the first year, and equity broker fees are excluded.

$\checkmark$ The model calculates depletion allowances on geothermal projects. The model also depletes certain AFUDC when appropriate. 
$\checkmark$ Income tax and other tax statements are prepared for Federal and state taxes paid as well as tax credits earned. Tax calculations include excise taxes, Federal, state and local taxes. Depreciation calculations used to capture after-tax cash flow can use either straight-line or MACRS. There is also a section to incorporate local property taxes and special tax assessments.

$\checkmark$ The assumptions section is fairly extensive and covers construction costs, debt acquisition, equity acquisition, capacity factors, fixed and variable O\&M inputs, financial factors such as interest rates, G\&A expenses, real escalation in O\&M charges, unfired fuel assumptions, byproduct credits, asset life, inflation rates, tax rates, property tax rates, insurance, investment tax credits, AFUDC, local gross receipts tax, and special property tax assessments.

$\checkmark$ Total plant cost (overnight) is divided into: sales tax; rotor, gearbox, generator; tower and civil work; controls, transformer, interconnect; design/engineering; permitting/ environmental, construction labor and supervision; contingency; home office overhead; real escalation in construction cost; miscellaneous depreciable cost (last year of construction); sales tax on miscellaneous depreciable cost; land cost; and startup cost.

\section{ECIP Module}

The FATE2-P model also includes a life-cycle cost module based on the Buildings Life-Cycle Cost (BLCC) model (produced by the National Institute of Standards and Technology) and a MILCON ECIP module, which in turn fills out Form 1391. The ECIP module currently reflects 2009 forecast discount and inflation rates. The ECIP module provides values for first-year savings, simple payback, total discounted operational savings, SIR, and adjusted IRR.

\section{The Facility Energy Decision System (FEDS) Model}

FEDS is a building energy modeling software developed by PNNL to support the economic analysis of efficiency technologies at large, multi-building sites. Building characteristics are entered into the model using as much detail as possible, and the model uses the given information to make inferences for the remaining characteristics. Multiple sets of building data can be entered into the same model, so that an entire site can be represented at once. The optimization cycle uses data about the location of the site and the energy prices entered into the model to determine cost-effective retrofits for each set of building data, and to calculate costs and savings. The suggested retrofits can range from lighting to building envelope to heating and cooling, covering all aspects of a building's energy use and considering interactive effects. In addition, the model can be adjusted to consider just one type of retrofit. In this analysis, GSHPs were the only technology analyzed using FEDS at Fort Drum.

\section{Business Case Analysis Sources of Information}

DSIRE- Database of State Incentives for Renewables \& Efficiency. 2010a. Federal Incentive/Policies for Renewables and Efficiency: Business Energy Investment Tax Credit (ITC). Accessed April 23, 2010 at http://www.dsireusa.org/incentives/incentive.cfm?Incentive_Code=US02F\&re=1\&ee=1 (last updated June 10, 2009). 
DSIRE - Database of State Incentives for Renewables \& Efficiency. 2010b. New York: Incentives/Policies for Renewables \& Efficiency: Green Building Tax Credit Program (Corporate). Accessed April 23, 2010 at http://www.dsireusa.org/incentives/incentive.cfm?Incentive_Code=NY05F\&re=1\&ee=1 (last updated July 17, 2009).

DSIRE - Database of State Incentives for Renewables \& Efficiency. 2010c. New York: Incentives/Policies for Renewables \& Efficiency: Local Option - Solar, Wind \& Biomass Energy Systems Exemption. Accessed April 23, 2010 at http://www.dsireusa.org/incentives/incentive.cfm?Incentive_Code=NY05F\&re=1\&ee=1 (last updated November 11, 2009).

DSIRE - Database of State Incentives for Renewables \& Efficiency. 2010d. New York: Incentives/Policies for Renewables \& Efficiency: Renewable Portfolio Standard. Accessed April 23, 2010 at http://www.dsireusa.org/incentives/incentive.cfm?Incentive_Code=NY03R\&re=1\&ee=1 (last updated April 12, 2010).

DSIRE - Database of State Incentives for Renewables \& Efficiency. 2010e. New York: Incentives/Policies for Renewables \& Efficiency: New York - Net Metering. Accessed April 23, 2010 at http://www.dsireusa.org/incentives/incentive.cfm?Incentive_Code=NY05R\&re=1\&ee=11 (last updated March 23, 2010).

H.R. 1424. 2008. Emergency Economic Stabilization Act of 2008. Enrolled Bill. http://www.govtrack.us/congress/billtext.xpd?bill=h110-1424.

H.R. 6111. 2006. Tax Relief and Health Care Act of 2006 (Enrolled as Agreed to or Passed by Both House and Senate). Title II, Section 201. Summary available at http://www.govtrack.us/congress/bill.xpd?bill=h109-6111\&tab=summary.

JCT - Joint Committee on Taxation. 2007. Description of the Chairman's Modification to the Provisions of the "Heartland, Habitat, Harvest and Horticulture Act of 2007" (JCX-96-07). Available at http://www.jct.gov/publications.html?func=select\&id=19.

NYSDTF - New York State Department of Taxation and Finance. 1998. Instructions for Forms CT4, CT3, and CT-3-ATT: General Business Corporation Franchise Tax Returns. Accessed April 23, 2010 at http://www.tax.state.ny.us/ (last updated unknown).

NYSDTF - New York State Department of Taxation and Finance. 2010. Sales Tax Jurisdiction and Rate Lookup. Accessed on April 22, 2010 at http://www8.nystax.gov/STLR/stlrHome (last updated unknown).

NY State - New York State Power Naturally. 2004a. On-Site / Small Wind Incentives. Accessed June 2010 at http://www.powernaturally.com/Programs/Wind/incentives.asp?i=8 (last updated 2004). 
NY State - New York State Power Naturally. 2004b. PV Incentives. Accessed June 2010 at http://www.powernaturally.org/Programs/Solar/incentives.asp (last updated 2004).

TW - Town of Watertown. 2009. NYS - Real Property System. County of Jefferson, Town of Watertown. RPS345/V04/L001. Accessed at www.co.jefferson.ny.us/Modules/ShowDocument.aspx?documentid=1847 (last updated December 10, 2009).

Rushing, Amy S and Barbara C Lippiatt. 2009. Energy Price Indices and Discount Factors for Life-Cycle Cost Analysis - April 2009. NISTIR 85-3273-23 (Rev. 5/09). U.S. Department of Commerce, National Institute for Standards and Technology, Washington D.C.

United States Code. “26 USC § 48. Title 26. Internal Revenue Code. Subtitle A - Income Taxes. Chapter 1 - Normal Taxes and Surtaxes. Subchapter A - Determination of Tax Liability. Part IV - Credits Against Tax. SubPart E - Rules for Computing Investment Credit.

United States Code Service. 2006. “16 USC § 796 (2006). Title 16 - Conservation. Chapter 12-Federal Regulation and Development of Power. Subchapter 1 - Regulation of the Development of Water Power and Resources. Definitions. 2006.

United States Code Service. 2006. “26 USC § 168 (2006). Title 26. Internal Revenue Code. Subtitle A - Income Taxes. Chapter 1 - Normal Taxes and Surtaxes. Subchapter B Computation of Taxable Income. Part VI - Itemized Deductions for Individuals and Corporations.

U.S. Treasury - United States Department of the Treasury. 2009a. Publication 946: How to Depreciate Property. Internal Revenue Service. Washington, D.C. Accessed June 2010 at http://www.irs.gov/app/picklist/list/publicationsNoticesPdf.html (last updated April 26, 2010).

U.S. Treasury - United States Department of the Treasury. 2009b. Form 8835: Renewable Electricity, Refined Coal, and Indian Coal Production Credit. Internal Revenue Service. Washington, D.C. Accessed June 2010 at http://www.irs.gov/pub/irs-pdf/f8835.pdf (last updated 2009). 


\section{APPENDIX B}

Analysis of Biomass and Waste-to-Energy Opportunities 



\section{Appendix B: Analysis of Biomass and Waste-to-Energy Opportunities}

\section{Biomass and Waste-to-Energy Technology}

The term "biomass" refers to renewable fuels used for power production that include agricultural waste, forest and wood processing waste, animal waste, industrial waste, dedicated biomass crops, and methane from landfills and wastewater treatment plants. Waste-to-energy (WTE) is similar, but includes municipal solid waste (MSW) and construction and demolition (C\&D) waste as fuel sources. These feedstocks qualify as renewable sources for Energy Policy Act of 1992 (EPAct) compliance purposes, but some states and alternative goals have different feedstock requirements. While biomass and WTE projects may be very different as to their sources, fuel collection modes, and fuel cost profiles, in the end, energy production often relies on similar technologies.

The primary technologies for producing electricity rely upon steam turbines, gas turbines, or combined cycle turbine generators. Generators are energized by steam produced from direct combustion of raw material, or a synthetic gas (syngas) produced through anaerobic digestion or gasification. Direct combustion and anaerobic digestion technologies are mature and have been proven commercially. Gasification technologies are newer in the market, but are promising based on a number of successful installations. Anaerobic digestion is widely used but primarily for smaller applications in rural and municipal projects rather than large commercial installations.

Combustion systems burn biomass to produce steam in a boiler, turning a turbine connected to a generator. This method of producing electricity is quite inefficient, at about 20 to $30 \%$. In these systems, combustion products tend to form deposits on the heat transfer surfaces, increasing maintenance requirements and decreasing the lifetime of these surfaces as a result of corrosion

and erosion. Ash has to be collected and removed from the system. The variability of incoming feedstock in terms of its composition and moisture content can present problems in combustion systems, most notably with MSW and mixed feeds. Systems that use a more homogeneous feedstock benefit from more complete combustion, which increases efficiency and reduces combustion waste products and emissions. Various boiler designs try to address these issues.

Gasification is more efficient than combustion, but the technologies employed are not as mature or common in commercial operation. The two basic types of gasification are direct-fired (aerobic) and indirect-fired (anaerobic). Gasification uses oxygen (direct-fired systems only), steam, heat, and pressure to break down organic materials to produce syngas, which is primarily hydrogen and carbon monoxide. Syngas is cleaned to remove impurities, then is used to generate electricity in a gas turbine or fuel cell, or is used to produce transportation fuels and/or commercially valuable chemicals. The syngas resulting from direct-fired systems has a lower heating value than the syngas from indirect-fired systems, and requires significant upgrading and processing to be used as fuel. The inorganic materials are discharged as inert solids that can often be used for another purpose. There are many types of gasification designs that use different amounts of oxygen and steam at different stages and temperatures, producing different amounts of waste heat, syngas, and solids. 
Digesters tend to be smaller systems and are typically used just for biomass. They are usually located at the biomass source, such as farms with significant amounts of animal manure and wastewater treatment facilities. Digesters break down biomass in warm, wet environments to produce methane, which can be captured as fuel for generating electricity. Aerobic digesters are common in developing countries for production of heating and cooking fuel in rural areas. Anaerobic digesters limit the amount of oxygen in the gasification process, producing gas with a higher concentration of methane, which is better for power production. Because of the smaller size of digester systems, electricity is typically generated using fuel cells, microturbines, or reciprocating engines.

Methane is also produced through anaerobic digestion in landfills as the garbage underground breaks down. It has been left in the ground, but the risk of fire and greenhouse gas emissions has led the Environmental Protection Agency (EPA) to require landfills to remove the methane. The methane could be used in an electricity generation system if the economics are positive. The most economic opportunities for landfill methane capture and use are in cases where the landfill already has a collection system in place, is active or recently closed (methane production tapers off as landfills age), and has sufficient waste (typically at least 1 million tons) to generate a significant amount of methane. The landfill must be lined as well, to prevent water intrusion into the landfill that stifles digestion of the waste and methane production and to prevent the methane from migrating into the surrounding soil. New landfills are typically lined by regulation; many older ones are not. Methane production even from large landfills is relatively low; as a result, power facilities that use it are typically small systems located on site using fuel cells, microturbines, or reciprocating engines.

Even a "free" feedstock such as crop wastes, which is not currently collected nor located at one site, does not guarantee a successful project, because collection, transportation, and storage costs can be, and often are, economically prohibitive. The economics of MSW projects are typically more attractive than other biomass projects because fuel is often delivered free or even accompanied by payment in the form of a tipping fee. Most landfills are operated or franchised by a local government. Many of these derive operating revenues from fees that are added to the actual operating costs of the landfill. As a result, the tipping fee may be inflated over actual costs and therefore not an accurate representation of costs that can be avoided.

Emissions control requirements depend upon the process used and current regulations affecting the site. Some gasification processes (with gas scrubbers) produce no criteria pollutants, such as $\mathrm{SO}_{\mathrm{X}}$ and $\mathrm{NO}_{\mathrm{X}}$. However, air emissions are inevitable if the resulting syngas is burned in a conventional power generator. Consideration of emissions will have to be made regarding the approach to any proposed project. Plants owned and operated by third parties will qualify for separate permitting, so that may be the best option for Fort Drum.

\section{Siting Considerations}

For all of these technologies, except landfill gas, a power plant will require feedstock storage space, feedstock preparation equipment, feed equipment, processing equipment, product cleaning and collection equipment, electricity generation equipment, ash and waste storage space, water for steam and cooling, and emissions control equipment. The specific infrastructure and space required for each of these depends on the type of feedstock and process application, the amount 
of feedstock used, and existing site conditions. Permanent systems with infrastructure typically need up to 5 acres (excluding feedstock storage).

Some feedstocks require year-round storage, because they are only available seasonally (e.g., crop residue); some feedstocks are available almost continuously and require less storage space (e.g., MSW). A feedstock available continuously may need about 20 days of fuel stored in case of supply interruption, which can use about 40 acres of land, depending on the overall size of the plant. Most plants only store 3 to 5 days of fuel on site, requiring about 4 to 5 acres. Feedstocks available only once or twice a year will need hundreds of acres of land for storage. Some feedstocks can be compressed into uniform-sized pellets to simplify storage, transport, and combustion. However, the pelletization can add $20 \%$ to fuel costs. Storage areas may have to be located some distance away from the plant because of site constraints, but nearby storage is preferred to reduce operational costs.

Sufficient space was said to be available in the northern corner at Fort Drum's border and along the state road. These locations would allow truck access and other plant operational activities with minimal disturbance to daily post operations and mission.

\section{Biomass and Waste-to-Energy Analysis Approach}

The critical factor in determining feasibility for biomass energy generation is feedstock availability. There are a number of potential feedstocks that were evaluated for use at Fort Drum. The following questions were asked about each feedstock:

- Does this material exist in the surrounding region within 60 miles? (The maximum economic transport distance is assumed to be 30 to 60 miles.)

- How much is available within this area, on average? Is availability constant or variable, depending on crop rotation cycles and/or market conditions?

- How much is available for use as a feedstock? Availability is based on the feedstock being able to be collected and the lack of competing uses or markets. For example, wheat straw is typically left in the field to protect and rebuild the soil. If it is collected, the resulting bales may have higher value as animal bedding than as fuel, creating a competing market for what was otherwise a waste material on the ground.

- How much electricity can be produced from the available biomass? This is a function of the quantity of material available, moisture content, and its relative heat value.

In this analysis, if the electricity available from a feedstock was less than $1 \mathrm{MW}$, the feedstock was considered infeasible. The narrowed list of possible feedstocks was then evaluated on a simple economic basis. Feedstock costs were estimated based on tipping fees, collection costs, transportation costs, current market rates, and other relevant information. Other operational costs and construction costs were estimated by scaling existing plant data for the primary technology types. Based on the amount of feedstock available and the size of plant required, a levelized cost of electricity was estimated for each. Fort Drum's average electricity cost of

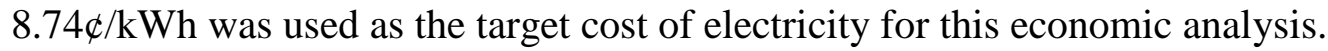


PNNL staff created a new tool that supports analyses of various plant sizes, costs, and fuel sources in a generic manner. This facilitates "what if" analyses where critical information about fuel source and cost is unavailable. The result is an estimate of what power from a project would cost using available data and staff assessments for missing data. It also allows staff to reverse engineer an answer using Fort Drum's power cost as a given. Specifically, the tool can be set up to provide an estimate of what size plant and fuel cost is needed to produce power for less than the current and projected future power rate. Data from a 2003 National Renewable Energy Laboratory (NREL) study of biomass fuels was used to initiate the analytic tool (Bain et al. 2003). The 2003 study costs were updated to 2010 values and scaled according to varying plant sizes following the methodology used in the study. Any size plant can be evaluated and any value can be varied to test for financial feasibility. The tool was only used for preliminary screening because it does not adequately address taxes, incentives, or other factors. These economic factors have a significant impact on project feasibility, especially if it is assumed the power project will not be owned and operated by the government.

If the analysis resulted in highly uneconomic estimated costs, the option was rejected. For any options that appeared to be reasonably close to cost-effective in the screening tool, further economic analysis was completed, including evaluating tax credits, other incentives, different financing options, and ranges of feedstock sources and amounts. Any risks or potential issues associated with these remaining project options were noted, to present all considerations surrounding an implementation decision. When possible, these were quantified.

\section{Biomass and Waste Resource Characterization}

The following biomass and waste types were assessed for potential as feedstocks.

- Agricultural (crop residues, animal waste, dedicated biomass crops)

- Forest (thinnings, logging slash)

- Industrial (mill residue, other industry waste)

- Waste (MSW, landfill gas, biogas or biosolids from wastewater treatment plants)

Agricultural Biomass

The USDA has a database of agricultural production information by county and state. Information was gathered here about crop and livestock production.

\section{Crop Residue}

Crop residues are the plant remains in the field after harvest. Some crops have more residues than others; some, like hay, have no residues at all because the entire plant is harvested. A certain amount of residue left on the soil minimizes erosion and maintains nutrients in the soil, and can provide habitats for game animals. However, too much residue can inhibit growth of a new crop. Depending on tilling practices, climate, crop type, soil type, and slope of the land, residue may or may not be available for removal. In general, conventional till practices need more residue than no-till practices; warm wet climates need more residue than cold dry climates; corn fields need more residue than wheat fields; coarse, well-drained soils need more residue than poorly-drained, heavy clay soils; and steeper slopes need more residue than flat land. In 
addition, crop residue availability is dependent on competing uses, like cattle feed, and seasonal yields, which can change dramatically from year to year.

In counties within 60 miles of Fort Drum, the major crops harvested that leave residues are corn, oats, wheat, and barley (USDA 2010). See Table B-1 for the number of bushels and amount of residue produced on an annual basis. The available residue for biomass energy generation will be somewhere between these values and zero. A rule of thumb is that about $30 \%$ of the residues can be collected. However, these numbers will have to be verified on a farm-by-farm basis for a more accurate analysis.

Table B-1: Crops and Biomass Production near Fort Drum

\begin{tabular}{|l|r|r|r|r||}
\hline & \multicolumn{1}{|c|}{$\begin{array}{c}\text { Bushels } \\
\text { Produced }\end{array}$} & $\begin{array}{c}\text { Tons Residue } \\
\text { Remaining }\end{array}$ & \multicolumn{1}{c|}{$\begin{array}{c}\text { Tons Collectable } \\
\text { Residue }\end{array}$} & \multicolumn{1}{c|}{$\begin{array}{c}\text { Potential Electricity } \\
\text { Generation }\end{array}$} \\
\hline Corn & $4,950,300$ & 136,993 & 41,098 & $4.94 \mathrm{MW}$ \\
\hline Oats & 171,260 & 3,425 & 1,028 & $0.12 \mathrm{MW}$ \\
\hline Wheat & 48,250 & 2,173 & 652 & $0.08 \mathrm{MW}$ \\
\hline Barley & 62,700 & 1,568 & 470 & $0.06 \mathrm{MW}$ \\
\hline Total & $\mathbf{5 , 2 3 2 , 5 1 0}$ & $\mathbf{1 4 4 , 1 5 9}$ & $\mathbf{4 3 , 2 4 8}$ & $\mathbf{5 . 2 0} \mathbf{M W}$ \\
\hline
\end{tabular}

It would cost about $\$ 10 /$ ton to transport the residues to the plant, and about $\$ 10 /$ ton for the farmer's collection effort. Therefore, crop residue feedstock cost is about $\$ 20 /$ ton. Using all crops together to gain the most benefit from economy of scale, the most cost-effective biomass option would be combustion, producing electricity at $13.7 \$ / \mathrm{kWh}$. This is more expensive than Fort Drum’s rate $(8.74 \$ / \mathrm{kWh})$, making it an unattractive option to pursue at this time.

Furthermore, crop residue may not be a reliable energy resource because of varying crop yields and alternative markets. Availability is dependent on seasonal yields, which can change dramatically with crop rotation, market conditions, and weather patterns. Availability is also dependent on competing uses, including livestock feed, which often pays almost $\$ 42 /$ ton for corn stover and over \$21/ton for wheat straw (Gallagher et al. 2003), and may be located closer to the source. Therefore, it is not recommended to pursue crop residues at this time.

\section{Animal Waste}

Manure from cattle, swine, and poultry farms is generally reclaimed from animal housing and feeding areas and used as fertilizer for crops. This has become a problem because of overapplication. Bad odors and groundwater contamination are forcing farmers to find other ways to dispose of manure. Furthermore, greenhouse gas emissions are now more strictly regulated, so emissions from manure must be controlled. Anaerobic digestion technologies can turn wet manure into energy, and often can be used with existing collection and treatment systems. Poultry waste can be used directly in combustion or gasification systems because it has lower moisture content than cow or swine manure.

Over the 2-year period of 2008-2009, the average population was 101,950 head of cattle within 60 miles of Fort Drum, none of which are on site (USDA 2010). There are no known poultry farms and a negligibly small number of swine farms in the area. All of the cattle may be kept in pastures instead of feedlots, but at a minimum, the beef cattle (2-year average of 9,700 head) can 
be assumed to be pastured. Manure in pastures is not good feedstock material because it is not typically collected (increasing the costs and decreasing the heating value as it breaks down over time and releases its nutrients). Only the manure from cattle on a feedlot can be assumed to be available for electricity generation, which may be the manure from the remaining 2-year average population, 92,250 head of milk cattle. This number would have to be verified on a farm-byfarm basis for accuracy.

If all of these cattle were considered, the manure could generate about $11.0 \mathrm{MW}$ of electricity using an anaerobic digester. However, using manure to generate energy any distance from the source will not be cost-effective. Cow manure is only $12 \%$ solids as excreted, and then is typically collected with a flush system, watering it down even further. On a dry basis, manure has an energy content of about $17 \mathrm{MMBtu} / \mathrm{ton}$, and is transportable, but wet manure has an energy content of about $2 \mathrm{MMBtu} /$ ton or less. Drying the manure on site would incur costs to the farm, and then the manure would have to be sold at a profit for the farmer. These costs would be in addition to the transportation costs, which would typically be about \$10/ton. Transporting wet manure would increase costs (as a result of increased volume and hence increased number of trucks) beyond what is economically feasible. Because of the expenses of liquid removal, transportation, and anaerobic digestion equipment, using manure for energy generation at Fort Drum is not feasible.

\section{Dedicated Crops}

The most common dedicated energy crops include switchgrass, hybrid poplar, willow coppice, and other short rotation woody crops (SRWC). Energy crops are fast-growing plants that can be harvested for use as energy in various forms. Switchgrass is a native prairie grass that grows best in warm dry climates like the Midwest. SRWC need lots of water and do well in colder climates like the Northeast. They need at least 16 inches of rainfall per year, or need to be located near a body of water. Using dedicated crops as biomass is an option, but they are not always a readily available resource. Rather, agricultural land where the crops can be grown is the resource to be evaluated, and the feedstock cost would be based on the cost to farm that land, harvest the resource, and deliver it to the generation plant on post.

Willow and switchgrass are the most likely energy crops that would grow well near Fort Drum. According to De La Torre Ugarte et al., the production costs of willow in the Fort Drum region would range from $\$ 17.77 /$ ton to $\$ 30.46 /$ ton, with an average of $\$ 20.47 /$ ton. Switchgrass production would range from $\$ 21.38 /$ ton to $\$ 25.10 /$ ton, averaging $\$ 22.53 /$ ton (De La Torre Ugarte et al. 2000). To use this material in a biomass plant on site, a transportation cost of $\$ 10 /$ ton would be added to the production cost. In addition, compensation for the farmer would be required.

Willow would be the most economic feedstock choice; at this price with no compensation, it would require a $45-\mathrm{MW}$ (at $8.74 \mathrm{\$} / \mathrm{kWh}$ ) gasification plant to generate cost-effective electricity, using over 200,000 tons of willow per year. Fort Drum's average load is $15 \mathrm{MW}$, which means $30 \mathrm{MW}$ would have to be sold back to the utility or Defense Energy Support Center (DESC), who purchases power for the Department of Defense (DoD). This may not be possible, and at the very least it complicates the contracting procedure to the extent that the project would only be worthwhile to pursue if it was extremely beneficial to DoD. Because of these contracting 
issues and the land area required for that amount of feedstock production (over 40,000 acres), dedicated energy crops are not a realistic biomass option.

\section{Forest Thinnings and Logging Slash}

Logging slash includes branches, stumps, and other material that is generated during logging practices but left behind because it is not useful to the loggers seeking large tree trunks. Once this slash is cut and left on the forest floor, it dries out, becoming good fuel for fires. It also can get in the way of machinery during replanting efforts. Sometimes it is gathered into small piles and burned in a controlled manner to reduce the risk of widespread forest fire, but this practice pollutes the air and may be restricted by air quality regulations. Instead, it can be collected and transported to a biomass facility where the emissions can be controlled and the wood waste can be used to generate energy.

Fort Drum has about 40,000 forested acres of land, and approximately 1,500 acres are cut down annually for the purposes of timber sales and forest thinning. Logging activities are restricted to between April $1^{\text {st }}$ and October $1^{\text {st }}$ to avoid disturbing the Indiana bat, which seasonally resides on Fort Drum property and is an endangered species (Heap 2010). Fort Drum sells wood chips from their logging residue at about $\$ 3 /$ ton to $\$ 5 /$ ton, and it is estimated that around 150 tons of slash are collected annually from this operation. Forested areas within 60 miles of Fort Drum produced about 92,600 tons of collectable slash in 2007, assuming a 50\% recovery factor (US Forest Service 2010). It is assumed it would cost about $\$ 10 /$ ton to transport this off-site wood waste to an on-site biomass plant, and about $\$ 2 /$ ton for the collection effort, for a total of $\$ 12 /$ ton (Haq 2002).

Using these values, about $10 \mathrm{MW}$ could be generated at $10.12 \$ / \mathrm{kWh}$, which is close to Fort Drum's current rate, but not competitive. Greater quantities of available fuel feedstock would allow for a larger plant, improving the economies of scale. To have a cost-effective wood-fired biomass plant for large-scale electricity generation, regional logging slash would have to be supplemented with other sources of woody biomass such as mill residue and urban wood waste.

Fort Drum received an unsolicited proposal to provide Fort Drum electricity generated from a woody biomass facility located on land leased from Fort Drum. The facility would be a retrofit of the retired coal-fired power plant on Fort Drum, and would generate $38 \mathrm{MW}$ of electricity for use on Fort Drum and by other DoD facilities or local entities. The New York State Energy Research and Development Authority (NYSERDA) has agreed to buy the project's renewable energy credits (RECs). The sale of RECs will lower the cost of energy to Fort Drum, and if Fort Drum can then purchase less expensive replacement RECs, the project will get double credit towards EPAct goals for generating renewable power and being located on Federal property.

There are a number of concerns with the proposal, however, and these are currently being discussed among Fort Drum, the development company, DESC, and other involved parties. The question of greatest concern to Fort Drum, not necessarily limited to this particular proposed project, is whether the project will be beneficial to $\mathrm{DoD}$, primarily in the form of cost savings. There are also logistical issues that will need to be resolved. 
If this facility were to be built, Fort Drum would be subject to National Grid's Service Classification (SC) 7, which would result in standby charges of over $\$ 300,000$ per year for 2 years, and less in the subsequent years. This value is dependent on the amount of power Fort Drum would need to purchase from the grid (when the biomass facility is down for maintenance or repairs) and for how long. Under the development company's current assumptions, Fort Drum electric costs would be slightly reduced compared to current rates, but these numbers are still being revised.

DESC purchases power for Fort Drum with power purchase contract terms of 5 years, typically. The development company has requested a different contract term and this possibility is being investigated. Furthermore, there are questions regarding whether this project would require a sole source agreement to sell not only Fort Drum's power, but also excess power. The entity that can legally purchase the excess power is also yet to be determined.

The plant will use approximately 500,000 tons/year of wood chips, which this assessment did not find to be available in the region. However, the development company has local experience in the industry and acquisition of the feedstock is not a critical concern at this point.

Fort Drum also had an opportunity to investigate the possibility of a small-scale woody biomass project in the form of free feasibility studies currently being offered by the U.S. Forest Service and conducted by Yellow Wood Associates, Inc., a consulting firm based out of St. Albans, Vermont. Potential candidates for a project that falls under the scope of this free study were discussed during the site visit, and the most promising seemed to be a small cogeneration unit located between the support maintenance activity (SMA) building (bldg \# 4530) and the department of logistics (DOL) warehouse (bldg \#4525). These two large buildings (314,563 square feet total) are located next to each other with enough space between them to house the cogeneration equipment and a supply of wood chips as feedstock. For this scenario to qualify, these two buildings would have to be disconnected from the grid, with the wood chip plant as the primary source of power and a diesel or propane generator as a backup in case of interrupted feedstock supply. Biomass projects at a scale this small are typically not economic, and the Director of Public Works at Fort Drum declined the study opportunity. PNNL concurs that it is unlikely the study would have resulted in a feasible project.

While there are a number of concerns with the proposal, it is, for now, the only potentially feasible option for biomass and large-scale renewable energy generation at Fort Drum. It is recommended to proceed with the verification of assumptions and investigation into legal issues required for implementation. If final pricing analysis results in savings for Fort Drum and the necessary contracts can be signed, Fort Drum should move forward with the proposal and purchase renewable biomass power.

Industrial Biomass

Industrial biomass includes mill residue, food processing waste, textile waste, or waste from other specialized operations. 
There are many types of mills that use wood to produce various products, including lumber, shake and shingle, pulp, veneer and plywood, log chips, and posts, poles, and pilings. These processes generate waste in the form of sawdust and wood pieces, which are useful materials.

The U.S. Forest Service has a database with information for timber industry outputs by county and state. Recent information regarding mill residues was unavailable for counties in the Fort Drum region, but 2001 data was available. A large number of mills exist in the area surrounding Fort Drum, but in 2001 the majority of the byproducts were already used for other purposes, primarily fiber and fuel. Unused mill residues measured 4,360 tons, and accounted for only $2.4 \%$ of total residues. The electricity generation potential from this small amount of unused residue is about $0.5 \mathrm{MW}$. It should be noted that this data is almost ten years old, and the situation regarding available mill residue in the Fort Drum area could have changed markedly since 2001, but it is still very unlikely that more than $1 \mathrm{MW}$ could be generated using only mill residue.

\section{Other Residue}

According to the New York State Department of Environmental Conservation's 2009 Directory of Primary Wood-Using Industry in New York State, 35 companies exist in the area surrounding Fort Drum that produce wood products such as cants, rough or planed lumber, wood chips, crates, pallets, railroad ties, and furniture. Most of these companies are sawmills or have a sawmill integrated into their operation (NY State 2009). The total capacity of these timber production facilities ranges from 77 to 141 million board feet, which equates to approximately 6.5 to 11.7 million cubic feet of product. Communications with Fort Drum personnel indicated that large amounts of unused scrap wood exist at these facilities, and that local paper mills are being converted to wood chipping facilities (Richardson 2010, Rowley 2010). Fort Drum might be able secure these resources, which, if used in conjunction with regional logging slash, could make electricity generation from wood biomass a feasible option.

The amount of available residue and cost of acquiring that residue will have to be verified on a site-by-site basis. Fort Drum would have to provide a competitive price for the residue, which would reduce the economic feasibility of using this industrial wood waste. At this time, Fort Drum should be aware that these additional sources of wood are potentially available for use, but the number of contracts required to obtain these sources is something that a developer (like CRC) would need to investigate and decide whether or not to use as a portion of the feedstock in a woody biomass facility.

\section{Waste Biomass}

Municipal Solid and Urban Wood Waste

MSW and C\&D waste are being generated at greater rates each year while landfills are filling up, resulting in greater hauling distances and increasing prices for waste disposal. Recycling is one way to reduce the strain on landfills; using the waste to generate energy is another. Some recyclables, like metals, must be separated out before waste is used for energy generation. All carbon-based materials, however, can be used to generate energy. 
Fort Drum generates approximately 4,600 tons of MSW per year. This waste is currently hauled to the Development Authority of the North Country (DANC) Rodman landfill. Fort Drum pays about $\$ 60 /$ ton for the collection, transportation, and disposal of this waste; $\$ 41 /$ ton from this amount is for landfill tipping fees. If Fort Drum were to combust all of this waste in a WTE facility, only $0.5 \mathrm{MW}$ could be generated at a cost of $19.0 \$ / \mathrm{kWh}$. (This scenario assumes a feedstock cost savings of $\$ 41 /$ ton, to account for the fact that Fort Drum would no longer be paying a tipping fee.) The cost of electricity would be more than double Fort Drum's current

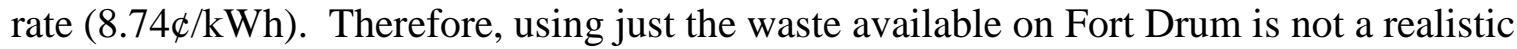
option.

For Fort Drum to implement an economically feasible WTE project, MSW would need to be transported on post from the surrounding region. Army Regulation 420-1 states "Army-owned and Army-operated solid waste management (SWM) facilities will not be used as a municipal or regional SWM facility or as the SWM facility for surrounding communities, unless operated under an approved Enhanced Use Lease type agreement" (Army Energy Program 2010). A third-party owned and operated WTE project could conceivably use an EUL type agreement because while it would be on Army land, it would not be Army owned or operated.

Another consideration with respect to using off-site waste is that Fort Drum would need to divert waste from the DANC Rodman Landfill. This might meet with local political opposition. In addition, there may be on-site opposition to a WTE project.

A resource characterization of the surrounding region was conducted so that Fort Drum will have the data available to pursue a WTE project, regulatory and political issues allowing.

Jefferson County operates a waste transfer station on NYS Route 12 in Pamelia, about 4.5 miles north of the city of Watertown. The County transfers around 36,000 tons of MSW annually to the DANC Rodman Landfill. The DANC landfill is the major waste collection location in the immediate vicinity of Fort Drum. It is located on NYS Route 177 in the Town of Rodman, about 15 miles south of Fort Drum, and receives an average of 273,600 tons of waste per year. The only other active MSW landfill within 60 miles of Fort Drum is the Ava landfill, which is operated by the Oneida-Herkimer Solid Waste Authority and located near the city of Boonville, approximately 50 miles southeast of Fort Drum. These landfills are summarized, with their respective tipping fees, in Table $\mathrm{B}-2$. 
Table B-2: Waste near Fort Drum

\begin{tabular}{||l|l|r|r|r|r|c||}
\hline \multicolumn{1}{|c|}{ Site } & \multicolumn{1}{|c|}{$\begin{array}{c}\text { Collection } \\
\text { Location }\end{array}$} & $\begin{array}{c}\text { Miles } \\
\text { from } \\
\text { Drum }\end{array}$ & $\begin{array}{c}\text { Tipping } \\
\text { Fee, \$ }\end{array}$ & $\begin{array}{c}\text { Assumed } \\
\text { Cost } \\
\text { Savings, \$ }\end{array}$ & $\begin{array}{c}\text { Available } \\
\text { MSW, } \\
\text { tons/year }\end{array}$ & $\begin{array}{c}\text { Potential } \\
\text { Electricity } \\
\text { Generation, } \\
\text { MW }\end{array}$ \\
\hline \hline Fort Drum & Fort Drum & 0 & $\$ 41.00$ & $\$ 20.50$ & 4,600 & 0.5 \\
\hline $\begin{array}{l}\text { Jefferson County } \\
\text { Transfer Station }\end{array}$ & Pamelia, NY & 5 & $\$ 41.00$ & $\$ 20.50$ & 36,000 & 4.0 \\
\hline $\begin{array}{l}\text { DANC Rodman } \\
\text { Landfill }\end{array}$ & Rodman, NY & 15 & $\$ 41.00$ & $\$ 20.50$ & 273,600 & 30.1 \\
\hline $\begin{array}{l}\text { Oneida-Herkimer } \\
\text { (Ava) Landfill }\end{array}$ & Boonville, NY & 50 & $\$ 57.80$ & $\$ 28.90$ & 253,900 & 28.0 \\
\hline \multicolumn{7}{|l}{} \\
\hline
\end{tabular}

${ }^{1}$ MSW from Fort Drum and the Jefferson County Transfer Station is sent to the DANC Rodman Landfill; therefore tonnage and potential electricity generation numbers from those sites are included in the numbers reported for DANC.

The assumed cost savings for each site is discounted 50\% from the tipping fee, to account for any additional transportation needs and incentives to deliver waste to a new location. Tipping fees fund recycling programs and other waste management operations, so the city or county may want to retain a portion of the revenue to continue operating these programs.

Fort Drum's waste and the regional waste were evaluated as potential sources of feedstock for a hypothetical WTE plant. The Rodman Landfill is projected to be at capacity by 2018 (DANC 2009). Closure of this landfill would put a severe strain on the waste disposal capabilities of the surrounding region, possibly making a WTE project that diverts waste from the landfill an attractive option. However, the Development Authority is currently seeking an expansion to the landfill that would extend its useful life to 2065, and it will likely be approved. DANC hopes to have the final permit for the expansion by the end of 2010.

Commercial C\&D waste is often primarily comprised of concrete, asphalt, or other materials that do not break down easily, thus it is typically not available for energy generation. Fort Drum generates approximately 1,300 tons of $C \& D$ waste annually, which is largely free of concrete and non-combustible materials. It is currently hauled to the DANC Rodman facility along with the MSW, but could be diverted as an additional fuel feed source if a biomass or WTE facility is pursued. It could be diverted, separated, and used in a WTE facility if additional feedstock is needed, but there will be additional costs associated with separating the waste, and it would not be a significant contribution in terms of generation amount.

The technologies considered for waste conversion include combustion and gasification, and some options were cost-effective in the screening analysis. See the Findings section below for the economic analysis of using MSW for electricity generation.

$\underline{\text { Landfill Gas }}$

Methane generated from decomposing waste is a combustible pollutant that must be controlled. It is typically vented or collected and flared to avoid buildup and danger of explosion. New 
greenhouse gas regulations are expected to require collection of landfill methane. Collected methane can be used as a fuel to generate heat or electricity.

There are a couple of WWII-era landfills on Fort Drum that have been closed for over fifty years. The nearby Town of Le Ray and village of Black River have landfills that were capped in 1990 and 1992, respectively. None of these are good candidates for landfill gas collection because methane production rapidly declines after a landfill is closed. (High-potential landfill gas production sites are typically still open or have been closed for five years or less.) Therefore, landfill gas is not available as an energy generation resource for Fort Drum.

\section{Wastewater Treatment Plant Sludge}

Wastewater treatment plant (WWTP) sludge is what remains after wastewater is treated and the clean water is returned to the ground or other body of water. It has high energy content when dried, but the drying process is energy-intensive and necessary before transportation. Sludge is similar in substance to manure; it is a very watered-down substance that is best processed on site, where methane is generated with anaerobic digestion. Therefore, only on-site sources of sludge are reasonable to use for energy generation.

Because wastewater produced at Fort Drum is sent off site to the city of Watertown for treatment, there are no on-site sources of sludge available for use as a feedstock.

\section{Biomass and Waste-to-Energy: Economic and Other Analysis Parameters}

The capital cost of biomass plants ranges from about $\$ 1,500$ to $\$ 7,000 / \mathrm{kW}$, depending upon scale and specific technologies used (Aabakken 2006). Smaller projects cost much more per $\mathrm{kW}$, resulting in higher energy costs, while larger projects cost less per $\mathrm{kW}$, resulting in more affordable energy costs. Direct combustion technologies tend to be both larger and less capitalintensive than those based on syngas.

Data used in this analysis were obtained from local sources when possible, and the economic assumptions were generally conservative. Our assumptions are presented in the report. However, any significant changes to important assumptions may change outcomesopportunities that are just barely economic in this report may no longer be economic if the values are changed significantly.

Biomass and WTE options were analyzed using Energy Conservation Investment Program (ECIP) and independent power producer (IPP) funding scenarios; an IPP is more likely to be used. Cost-effectiveness for ECIP projects is determined with savings-to-investment ratio (SIR) values (greater than 1.0), and the internal rate of return (IRR) shows whether the IPP scenario is cost-effective (greater than 10\%). The economic assumptions used to analyze each scenario, including available incentives, are listed in Table B-3. The average cost of electricity that Fort Drum would pay for the renewable energy was assumed to be $8.74 \overleftarrow{\$} / \mathrm{kWh}$. 


\section{Findings: Biomass and Waste-to-Energy Opportunities}

The availability of mill residue, landfill gas, and WWTP sludge is inadequate to consider a large biomass generation project. Other potentially available biomass fuels such as crop residues, animal waste, and dedicated energy crops cannot support economic electricity generation at this time. Wood waste in the region may be able to be used in an economic project based on the unsolicited proposal received by Fort Drum, but the feasibility of that project is questionable and currently under investigation. A new biomass plant using wood waste is not economic. Off-site MSW could be used in an economic WTE plant, and the economics of two potential plants are presented below. 
Table B-3: Economic Assumptions, constant $\$ 2010$

\begin{tabular}{|c|c|}
\hline \multicolumn{2}{|l|}{ Economic Factors } \\
\hline Inflation & $1.2 \%$ \\
\hline Interest Rate & $10.0 \%$ \\
\hline Debt/Equity Ratio & N/A \\
\hline Real Discount Rate & $3.0 \%$ \\
\hline \multicolumn{2}{|l|}{ Tax Considerations } \\
\hline Federal Depreciation & MACRS \\
\hline Federal Tax Rate & $35 \%$ \\
\hline State Income Tax Rate & $7.1 \%$ \\
\hline State Sales Tax & $7.8 \%$ \\
\hline Property Tax Rate & $0.7 \%$ \\
\hline \multicolumn{2}{|l|}{ Incentives } \\
\hline Federal Production Tax Credit & $\$ 0.011 / \mathrm{kWh}$ \\
\hline State Production Tax Credit & $\$ 0.000 / \mathrm{kWh}$ \\
\hline Federal Energy Tax Credit & $0 \%$ \\
\hline State Energy Tax Credit & $0 \%$ \\
\hline Utility Rebate & $\$ 0 / \mathrm{kW}$ \\
\hline \multicolumn{2}{|l|}{ Technology } \\
\hline Plant Life & 30 years \\
\hline $\begin{array}{l}\text { Capacity Factor (basis net kW } \\
\text { output): Total System }\end{array}$ & $85 \%$ \\
\hline $\begin{array}{l}\text { Real Escalation in Construction } \\
\text { Cost }\end{array}$ & $0 \%$ \\
\hline $\begin{array}{l}\text { Misc. Depreciable Cost (last } \\
\text { year of construction) }\end{array}$ & $\$ 0$ \\
\hline $\begin{array}{l}\text { Sales Tax on Misc. } \\
\text { Depreciation Cost }\end{array}$ & $\$ 0$ \\
\hline Land Cost & $\$ 0 / \mathrm{kW}$ \\
\hline Startup Cost & $\$ 0 / \mathrm{kW}$ \\
\hline
\end{tabular}

\section{Municipal Solid Waste}

Multiple off-site MSW scenarios showed favorable economics in the initial screening. A detailed economic analysis was conducted for two of the most likely cases. The first scenario analyzed was the use of waste from the Jefferson County Transfer Station, because of its close proximity to Fort Drum. In the event that DANC is not able to move forward with the planned expansion of the Rodman Landfill and an alternative for waste disposal is needed, a scenario was also analyzed for a WTE plant sized to Fort Drum's current average electric load (15 MW) using waste diverted from the Rodman Landfill. Both scenarios are economically feasible, as shown in Table B-4. 
Table B-4: Site and Regional MSW Waste-to-Energy Results

\begin{tabular}{||l|c|c||}
\hline Waste Source & $\begin{array}{c}\text { Jefferson County } \\
\text { Transfer Station }\end{array}$ & $\begin{array}{c}\text { DANC Rodman } \\
\text { Landfill }\end{array}$ \\
\hline \hline Technology & Combustion & Combustion \\
\hline Plant Size & $4.0 \mathrm{MW}$ & $15.0 \mathrm{MW}$ \\
\hline Feedstock Amount & 36,000 tons/yr & 136,200 tons $/ \mathrm{yr}$ \\
\hline Total Plant Cost & $\$ 4,561.3 / \mathrm{kW}$ & $\$ 3,495.5 / \mathrm{kW}$ \\
\hline \multicolumn{1}{|c|}{ Capital Cost } & $\$ 4,233.2 / \mathrm{kW}$ & $\$ 3,244.1 / \mathrm{kW}$ \\
\hline \multicolumn{1}{|c|}{ Sales Tax } & $\$ 328.1 / \mathrm{kW}$ & $\$ 251.4 / \mathrm{kW}$ \\
\hline Fixed O\&M Cost & $\$ 186.0 / \mathrm{kW}$ & $\$ 104.8 / \mathrm{kW}$ \\
\hline Variable O\&M Cost & $-1.3 \$ / \mathrm{kWh}$ & $-1.3 \$ / \mathrm{kWh}$ \\
\hline Feedstock Cost & $-\$ 20.50 / \mathrm{ton}$ & $-\$ 20.50 / \mathrm{ton}$ \\
\hline \hline SIR & 1.5 & 2.2 \\
\hline Simple Payback & $9.5 \mathrm{years}$ & 6.3 years \\
\hline $\begin{array}{l}\text { Internal Rate of } \\
\text { Feturn (IRR), No }\end{array}$ & $11.11 \%$ & $16.69 \%$ \\
\hline \hline
\end{tabular}

${ }^{1}$ Sized to Fort Drum’s FY 2009 average electric load.

\section{Biomass and Waste-to-Energy: Next Steps}

It is recommended to proceed with the verification of assumptions and investigation into legal issues required to implement the proposed biomass conversion plant. If the final pricing analysis results in savings for Fort Drum and the necessary contracts can be signed, Fort Drum should move forward with the proposal and purchase renewable biomass power.

If regulatory and political issues can be resolved, Fort Drum should consider pursuing a WTE project. To implement a WTE project using MSW, the following steps must occur before issuing a request for information (RFI) and identifying potential developers:

- Quantify the amount of MSW that is actually available for use in a WTE facility, and verify what tipping fee(s) will accompany the waste.

- Determine potential locations for a WTE facility. A site is needed that is large enough for the conversion equipment, feedstock preparation, and access; has water and other utilities available; can be accessed by trucks for feedstock delivery; and can be connected to the electric grid. 
Biomass and Waste-to-Energy Sources of Information

Aabakken, J. 2006. Power Technologies Energy Data Book - Fourth Edition. NREL/TP-62039728. National Renewable Energy Laboratory, Golden, Colorado.

Army Energy Program. 2010. AR 420-1 Army Energy Program. Accessed October 2010 at http://army-energy.hqda.pentagon.mil/policies/ar_420_1.asp (last updated October 13, 2010).

Bain, RL, WA Amos, M Downing, and RL Perlack. 2003. Biopower Technical Assessment: State of the Industry and Technology. NREL/TP-510-33123. National Renewable Energy Laboratory, Golden, Colorado.

DANC- Development Authority of the North Country. 2009. Report to the Community 2009. Accessed April 2010 at http://www.danc.org/comm_reports.html (undated webpage).

De La Torre Ugarte, DG, ME Walsh, H Shapouri, and SP Slinsky. 2000. The Economic Impacts of Bioenergy Crop Production on U.S. Agriculture. Agricultural Economic Report No. 816, prepared by the University of Tennessee Agricultural Policy Analysis Center for the U.S. Department of Agriculture, Office of the Chief Economist, Office of Energy Policy and New Uses, Washington, DC.

Gallagher, P, M Dikeman, J Fritz, E Wailes, W Gauther, and H Shapouri. 2003. Biomass from Crop Residues: Cost and Supply Estimates. Agricultural Economic Report No. 819, United States Department of Agriculture, Office of the Chief Economist, Office of Energy Policy and New Uses, Washington, DC. Available at http://www.usda.gov/oce/reports/energy/AER819.pdf.

Haq, Z. 2002. Biomass for Electricity Generation. U.S. Energy Information Administration, Washington, D.C. Available at http://www.epa.gov/solar/pdf/haq_apr20.pdf.

Heap, Walker. 2010. Fort Drum Environmental Department. Personal communications. May 2010.

NY State - New York State Department of Environmental Conservation. 2009. Directory of Primary Wood-Using Industry in New York State. Accessed May 2010 at http://www.dec.ny.gov/lands/33306.html (undated webpage).

Richardson, Mike. Fort Drum Community Planner. Personal communications. May 2010.

Rowley, Steven. Fort Drum Energy Manager. Personal communications. May 2010.

US Forest Service - United States Department of Agriculture Forest Service. 2010. Forest Inventory \& Analysis Mapmaker Program on Timber Products Output Studies. Accessed April 2010 at http://www.fia.fs.fed.us/program-features/tpo/. (last updated November 30, 2009).

USDA - United States Department of Agriculture National Agricultural Statistics Service. 2010. Data and Statistics. Accessed April 2010 at http://www.nass.usda.gov/Data_and_Statistics/Quick_Stats/ (undated webpage). 
APPENDIX C

Analysis of Geothermal Plant Opportunities 



\section{Appendix C: Analysis of Geothermal Power Plant Opportunities}

\section{Geothermal Power Plant Technology}

Geothermal power plants use steam from hot water reservoirs found deep below the Earth's surface. The steam rotates a turbine that activates a generator, producing electricity. There are three commercial types of geothermal power plants used to generate electricity (dry steam, flash steam, and binary cycle), and several newer technologies are entering the marketplace (hot dry rock and engineered geothermal systems). The type of plant depends on the state of the fluid (steam, hot water, or mixed) and its temperature.

A binary cycle plant is used for this analysis because it is a proven technology and it operates on lower temperatures, which are more likely to be available.

- Dry Steam power plants use underground steam piped directly from wells to the power plant, where it passes through separators to remove small particles before it is directed into a turbine/generator unit. There are only two known underground resources of steam in the United States: The Geysers in northern California and Yellowstone National Park in Wyoming. The only dry steam plants in the country are at The Geysers.

- Flash Steam power plants use geothermal resources that produce high-temperature hot water or a combination of steam and hot water. This very hot water (reservoirs greater than $360^{\circ} \mathrm{F}$ or $182^{\circ} \mathrm{C}$ ) flows up through wells in the ground under its own pressure. As it flows upward and the pressure decreases, some of the hot water boils (flashes) into steam. The steam is then separated from the water and used to power a turbine/generator. Leftover water and condensed steam are injected back into the reservoir, making this a sustainable resource. Depending on the temperature resource, it may be possible to use a second flash tank, where more steam at a lower pressure is separated for generation (double flash plant).

- Binary Cycle power plants utilize a second fluid in a closed cycle to operate the turbine, instead of direct geothermal steam. These plants operate on water at lower temperatures of about $225^{\circ}-360^{\circ} \mathrm{F}\left(107^{\circ}-182^{\circ} \mathrm{C}\right)$. The heat from the hot water is used to boil a working fluid, usually an organic compound with a low boiling point. The working fluid is vaporized in a heat exchanger and used to turn a turbine. The water is then injected back into the ground to be reheated. The water and the working fluid are kept separated during the whole process, so there is minor or no contamination. The advantage of the binary cycle plant is that it can operate with lower temperature water by using working fluids that have an even lower boiling point than water. Binary power plants are available in smaller scales such as 200 to $1,000 \mathrm{~kW}$.

- Hot Dry Rock (HDR) geothermal production utilizes high temperature rocks found deep (several kilometers) below the surface by pumping high-pressure water down a borehole into a heat zone. The water captures the heat of the rock by traveling through fractures until it is forced out a second borehole and used to generate electricity. Once the water has cooled, it is pumped back underground to heat up again. This process is most easily utilized in locations with natural geothermal systems with existing cracks or pore spaces. 
- Engineered or Enhanced Geothermal Systems (EGS) are similar to HDR systems. In locations where there are few cracks and connected pore spaces, or little to no cracks or connectivity, cracks can be created or enhanced. The advantage of HDR or EGS is that geothermal resources can be captured for production in non-tectonically active regions. This technology is still very new and expensive.

\section{Geothermal Energy Analysis Approach}

In the 2005 DoD Renewable Energy Assessment, the Navy’s Geothermal Office was responsible for the DoD geothermal power assessment. That task was subcontracted to Innovative Technical Solutions, Inc. (ITSI). The Navy and ITSI ranked installations based on their assessment of potential. The utility-grade geothermal assessment included 18 installations identified by DoD. Of those installations, five sites were found to have high potential for utility-grade systems. Fort Drum was not found to be one of five sites with high potential for the occurrence of utility-grade geothermal systems, nor was it among the 23 sites that have potential for direct use applications (ITSI 2003).

This analysis utilized the information available from the DoD study, in addition to other readily available sources, to determine if the following conditions exist. These conditions demonstrate utility-grade geothermal potential.

- Existing power plant operation or developer activity

- One or more wells tested with temperatures in excess of $212^{\circ} \mathrm{F}\left(100^{\circ} \mathrm{C}\right)$ logged downhole (at depths less than 3,000 m)

- Demonstrated high fluid flow rates on the order of 1,000 gallons per minute (gpm) per MW

- Heat flow rates greater than $80 \mathrm{~mW} / \mathrm{m}^{2}$ (milliWatts per square meter)

- $\quad$ Other exploration data and information available $\left(\geq 212^{\circ} \mathrm{F}\left(100^{\circ} \mathrm{C}\right)\right.$ not proven).

Since the 2005 DoD geothermal assessment, additional research and development has been done on other geothermal development techniques that may be applicable to additional installations. This new information is interpreted for economic applicability.

\section{Geothermal Resource Characterization}

Geothermal resources include hot springs, geysers, and underground resources of pressurized water and steam accessible via wells, as well as dry steam, hot water, hot dry rocks, and lowtemperature geothermal heat. A known geothermal resource area is an area in which the geology, nearby discoveries, competitive interests, or other indicators show that potential for extraction of geothermal steam or associated geothermal resources are sufficient to warrant consideration.

For commercial use, it is necessary to have a geothermal reservoir capable of providing hydrothermal (hot water and steam) resources with sufficiently high flow rates. Successful geothermal electrical power generation requires fluid flow rates equal to or greater than 1,000 
gpm per MW. For example, $1.5 \mathrm{MW}$ of electricity at a reservoir temperature of $300^{\circ} \mathrm{F}\left(149^{\circ} \mathrm{C}\right)$ requires a flow rate of about 1,000 gpm (McKenna 2006).

Geothermal plants operate in regions with high heat flow rates. Heat flow values above 80 $\mathrm{mW} / \mathrm{m}^{2}$ are considered characteristic of a viable geothermal resource. Productive heat flows are generally greater than $150 \mathrm{~mW} / \mathrm{m}^{2}$ (Blackwell et al. 2003). According to a heat flow map of the United States (MIT 2006), the heat flow in the Fort Drum region appears to be $50-54 \mathrm{~mW} / \mathrm{m}^{2}$, indicating low potential.

Utility-grade geothermal energy requires temperatures in excess of $212^{\circ} \mathrm{F}\left(100^{\circ} \mathrm{C}\right)$ at depths less than $3 \mathrm{~km}$. According to Southern Methodist University's Geothermal Laboratory (SMU 2004), the temperature at $4 \mathrm{~km}$ depth at Fort Drum is about $122-167^{\circ} \mathrm{F}\left(50-75^{\circ} \mathrm{C}\right)$, confirming the lack of geothermal resources (Figure C-1).

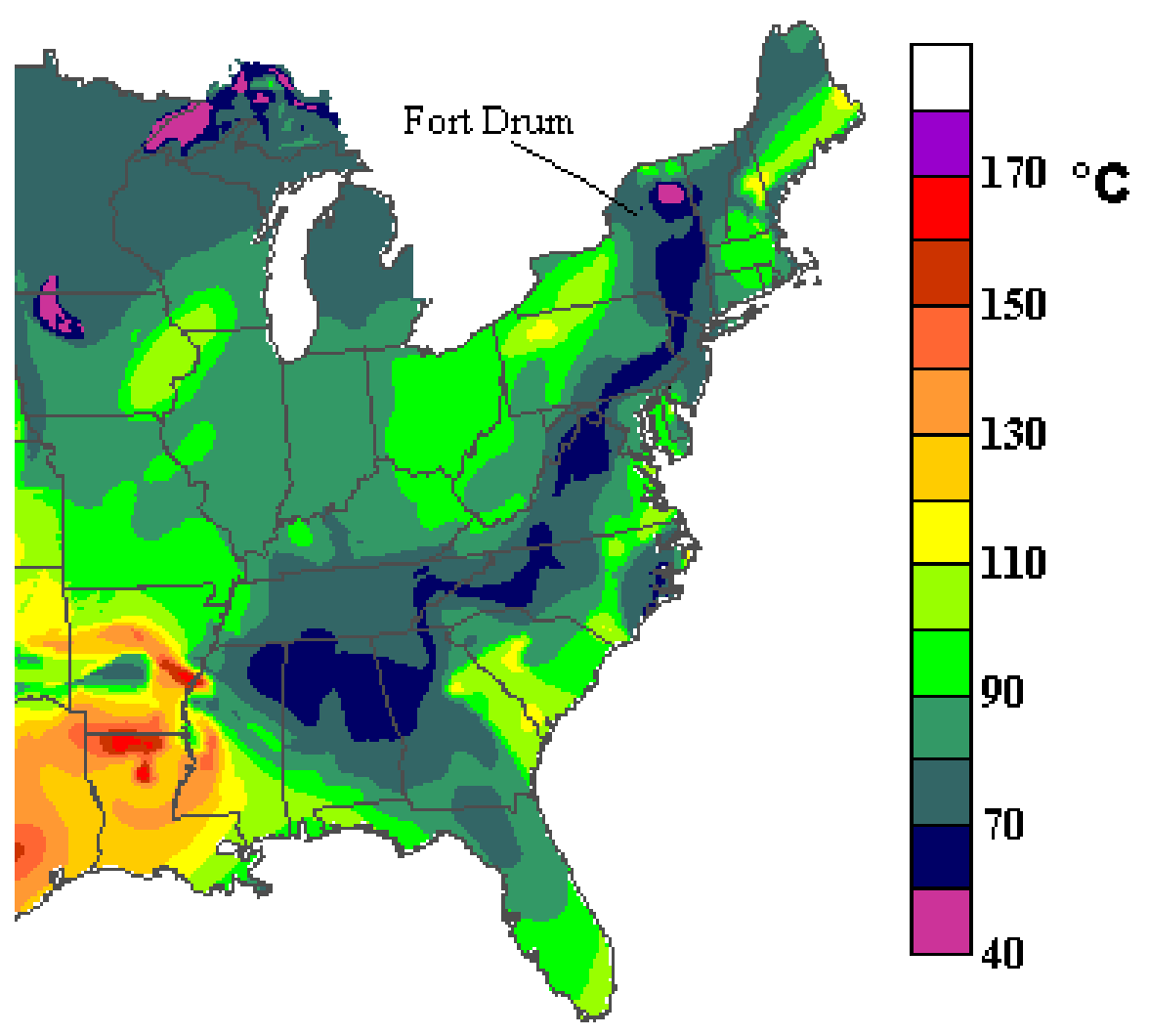

Figure C-1: Estimated Temperature at 4 km Depth for Eastern United States

Borehole geothermal data for the southeastern United States is available from the Geothermal Laboratory at Southern Methodist University. The nearest borehole for which measured heat flow data is available is located approximately 4 miles northeast of Fort Drum. The thermal gradient observed for this borehole down to $63 \mathrm{~m}$ depth is approximately $10^{\circ} \mathrm{C} / \mathrm{km}$. 


\section{Geothermal Power Plants: Economic and Other Analysis Parameters}

Geothermal power costs are influenced by capital costs for land, drilling, and the physical plant. Capital costs range from $\$ 1,500$ to $\$ 4,000$ per installed $\mathrm{kW}$. Capital costs for flash steam plants tend to be less expensive than binary plants. Plant life spans are typically 30 to 45 years.

Capital costs include:

- Initial development work: land leasing, exploration, permitting, test well costs

- Infrastructure: roads, water supply, utilities

- Well field drilling: production wells in addition to already drilled confirmation wells

- Steam and brine gathering system: pipes and brine separation equipment

- Power plant: physical equipment for energy conversion, including substation

- Interconnection: link of the power plant substation to the transmission corridor

- Soft costs: developers’ fees, overhead, financing costs, legal fees, etc.

Geothermal wells are drilled to depths of 200 to 1,500 meters for low- and medium-temperature systems. For high-temperature systems, wells are drilled 700 to 3,000 meters deep. Each well costs $\$ 1$ million to $\$ 4$ million to drill and a geothermal field may consist of between 10 and 100 wells.

The project cost is also affected by the cost of operation and maintenance (O\&M), the amount of power generated, and the market value of the power. Operating costs range from 0.4 to 2.6\$/kWh for conventional geothermal power plants (Shibaki 2003, Hance 2005). Operating plants at over $90 \%$ capacity will result in higher O\&M costs. Larger plant size means lower perkWh operating costs.

Economic calculations included in this analysis accounted for current Federal geothermal incentives - a 2.1\$/kWh renewable energy production tax credit (PTC) and 5-year accelerated depreciation.

The analysis assumed that electricity transmission lines located on or near a potential Fort Drum geothermal development area would be available to transmit power without substantial additional investment.

Further details on the analysis methodology and the economic and incentive parameters are documented in Appendix A, and the assumptions used are listed in Table C-1. 
Table C-1: Performance, Cost, and Economic Characteristics

\begin{tabular}{|l|l||}
\hline \multicolumn{1}{|c|}{ Characteristic } & \multicolumn{1}{c|}{ Value } \\
\hline Assumed temperature at $3,000 \mathrm{~m}$ & $144^{\circ} \mathrm{F}\left(62^{\circ} \mathrm{C}\right)$ \\
\hline Capacity Factor & $96 \%$ \\
\hline Technology Type & Binary \\
\hline Project Size & $10 \mathrm{MW}$ \\
\hline Estimated Annual Energy Production & $84,154 \mathrm{MWh}$ \\
\hline Energy Charge & $8.65 \$ / \mathrm{kWh}$ \\
\hline Total Capital Cost & $\$ 16,340 / \mathrm{kW}$ \\
\hline Variable O\&M Cost & $\$ 0.025 / \mathrm{kWh}$ \\
\hline 5-year accelerated depreciation & Included \\
\hline Federal 2.1 $/ \mathrm{kWh}$ PTC & Included \\
\hline Transmission Costs & Not Included \\
\hline \hline
\end{tabular}

\section{Findings: Geothermal Power Plants}

According to existing data, Fort Drum lacks naturally occurring hot water/steam fields and elevated temperatures at economic depths (less than 3,000 m). To reach the required temperature of at least $212^{\circ} \mathrm{F}\left(100^{\circ} \mathrm{C}\right)$, drilling to a depth of $8,000 \mathrm{~m}$ is required, resulting in high drilling costs.

The geothermal project scenario was evaluated for ECIP eligibility and IPP project potential. To qualify for ECIP funding, a project must achieve a savings-to-investment ratio (SIR) of 1.0, and its payback is also examined. For the IPP evaluation, the commercial cost of energy was calculated to obtain an internal rate of return (IRR) of $10 \%$. This was used as the minimum IRR required to attract the interest of a developer.

A geothermal project at Fort Drum was found not to be economic. Table C-2 lists the results of the analysis.

Table C-2: Performance, Cost, and Economic Characteristics

\begin{tabular}{|c|c|c|c|}
\hline Financing & \multicolumn{2}{|c|}{ ECIP } & IPP \\
\hline Economic Factor & SIR & $\begin{array}{c}\text { Simple } \\
\text { Payback, } \\
\text { years }\end{array}$ & $\begin{array}{c}\text { Cost of Electricity } \\
\text { at } 10 \% \text { IRR, } \\
\mathbf{c} / \mathbf{k W h}\end{array}$ \\
\hline $\begin{array}{c}10 \mathrm{MW} \\
\text { Geothermal } \\
\text { Project }\end{array}$ & 0.37 & 37 & 25.3 \\
\hline
\end{tabular}




\section{Geothermal Power Plants: Next Steps}

Because the geothermal resource is inadequate to support an economic project at Fort Drum, no immediate action should be taken. Considering the geology of the area in which Fort Drum is located, it is unlikely that there will be any changes in resource availability in the near future.

\section{Geothermal Power Plant Sources of Information}

Blackwell, D, K Wisian, M Richards, M Leidig, R Smith, and J McKenna. 2003. Geothermal Resource Analysis and Structure of Basin and Range Systems, Especially Dixie Valley

Geothermal Field, Nevada. Southern Methodist University Department of Geological Sciences. Dallas, Texas. http://www.osti.gov/energycitations/servlets/purl/813485smnwbs/native/813485.PDF.

Hance, Cédric Nathanaël. 2005. Factors Affecting Costs of Geothermal Power Development. Geothermal Energy Association for the U.S. Department of Energy, Washington, D.C.

http://www.geoenergy.org/publications/reports/Factors\%20Affecting\%20Cost\%20of\%20Geothermal\%20Power \%20Development\%20-\%20August\%202005.pdf.

ITSI - Innovative Technical Solutions. 2003. Geothermal Energy Resource Assessment on Military Lands. Innovative Technical Solutions, Inc. for the Department of Defense, NAWS China Lake, Walnut Creek, California. http://www.geothermal.org/GEO_0001.PDF.

McKenna JR. 2006. Increasing Electrical Power Capacity for Military Applications. U.S. Army Corps of Engineers Engineer Research \& Development Center, Vicksburg, Mississippi. http://www.smu.edu/geothermal/Oil\&Gas/Mckenna_Army\%20Corps.pdf.

MIT - Massachusetts Institute of Technology-led Interdisciplinary Panel. 2006. The Future of Geothermal Energy: Impact of Enhanced Geothermal Systems (EGS) on the United States in the 21st Century. INL/EXT-06-11746, prepared by MIT for the U.S. Department of Energy, Cambridge, Massachusetts. Accessed June 2010 at http://geothermal.inl.gov/publications/future_of_geothermal_energy.pdf.

Shibaki, Masashi. 2003. Geothermal Energy for Electric Power. A Renewable Energy Policy Project (REPP) Issue Brief, Renewable Energy Policy Project, Washington, D.C. http://www.crest.org/articles/static/1/binaries/Geothermal_Issue_Brief.pdf.

SMU - Southern Methodist University Geothermal Laboratory. 2004. Temperature at $4 \mathrm{~km}$ Depth. SMU Geothermal Laboratory, Dallas, Texas. Accessed June 2010 at http://smu.edu/geothermal/heatflow/4kmTempMap.gif (last updated unknown). 


\section{APPENDIX D}

Analysis of Ground Source Heat Pump Opportunities 



\section{Appendix D: Analysis of Ground Source Heat Pump Opportunities}

\section{Ground Source Heat Pump Technology}

Ground source heat pumps (GSHPs) use the stable temperatures of the earth and groundwater to improve the coefficient of performance of heating and cooling applications for buildings. Common GSHP configurations include open-loop, horizontal closed-loop, and vertical closedloop.

- $\quad$ Open-loop systems use open wells or bodies of water as direct heat transfer mediums to provide cool temperatures in the summer and warm temperatures in the winter. Heat transfer is only needed once, at the building, because groundwater is used directly, and the limited drilling and trenching results in a lower first cost.

- $\quad$ Closed-loop systems use heat transfer fluid inside a sealed pipe to exchange heat with the earth. Closed-loop systems have lower pumping requirements and are more efficient than open-loop systems. However, soil type and moisture content is more critical to the performance of these systems, and the trenching and drilling significantly increases first cost.

o In horizontal loops, all the piping lies at the same depth in the ground. The piping is laid in shallow trenches, and heat transfer takes place across the pipe wall between the fluid and the subsurface soil.

o Vertical closed-loop GSHPs operate using the same mechanism as horizontal ground loops, except that the piping is deployed in vertical boreholes. This is the most efficient configuration due to the more consistent soil temperatures at the depth reached by most boreholes.

GSHPs are applicable in almost any building with both heating and cooling. They can be used in buildings as small as 100 square feet, or up to 1 million square feet. Multiple GSHPs can be used in a single building or the same ground loop can be shared between buildings.

To install GSHPs at a building, the surrounding area will have certain prerequisites, depending on the type of GSHP. Open-loop GSHPs need a water source and sink. The source can be a well or open body of water. After the energy transfer has occurred, the water can be rejected to a secondary well, the open body of water used as the source, another body of water, or a storm drain. Water volume requirements depend on the size of GSHP installed, but typically between 1.5 and 3.0 gallons per minute are needed per cooling ton. This high water use greatly affects the feasibility of open-loop systems in some areas, as do local codes and regulations. Many locales do not want to risk groundwater depletion or contamination. Fort Drum also has this concern. In addition, open-loop systems require heat exchangers to separate the building water from the groundwater. It can be expected that the groundwater will eventually foul the heat exchanger, which will necessitate heat exchanger maintenance. With Fort Drum's limited maintenance staff, this upkeep is unlikely and would result in the systems not functioning properly.

Horizontal closed-loop GSHPs have a different limiting factor: sufficient land area. The heat transfer for these systems occurs in pipes laid in trenches that are between 100 and 400 feet long 
per cooling ton, spaced between 6 and 12 feet apart and about 6 feet deep. The soil characteristics and number of pipes per trench determine the pipe length; more pipes (up to six) per trench save land space but require more piping per ton of cooling capacity. The trenching costs make horizontal ground loops more expensive to install than open-loop systems, but if water availability is the only limiting factor, these systems tend to be the most economic.

Where significant land area and water volume is not available, vertical closed-loop GSHPs may be the only option. In these systems the heat transfer pipes are placed vertically in the ground, at depths of between 75 and 300 feet. Some land area is still required, because the pipe wells need to be spaced at least 15 to 20 feet apart, and 200 to 600 feet of piping are needed per cooling ton. Vertical ground loop systems tend to have the highest first cost of all the GSHP systems because of the cost of drilling multiple bore holes.

The tradeoff between land use, water use, and first cost generally determine which GSHP is appropriate for a particular building. All of these factors need to be taken into account when planning to deploy a GSHP system.

\section{Ground Source Heat Pump Analysis Approach}

The Facility Energy Decision System (FEDS) building energy model was used to develop a representation of Fort Drum based upon a 2002 PNNL data-gathering trip. Building data were entered for groups of similar buildings based on age, size, and use type. Table D-1 shows the general characteristics of buildings in each group and Table D-2 shows which buildings are in each group (groups in which no buildings were found to be economic candidates for GSHPs and buildings that are on the planned demolition list have been excluded from Table D-2 for brevity). Although Tables D-1 and D-2 include WWII-era buildings, Fort Drum does not intend to install GSHPs in such buildings. The 2002 FEDS model was updated with current fuel, equipment, and labor prices, and fuel use information to determine cost-effectiveness for GSHPs across the sites.

Additional FEDS analysis was performed to account for potential GSHP projects in buildings that were constructed after 2002. To determine the performance of the three GSHP configurations in newer construction, administration buildings and barracks with varying characteristics were entered into FEDS. This analysis allowed for the determination of costeffectiveness for GSHPs in a range of "typical” recently constructed buildings.

Site-specific TMY (typical meteorological year) weather data for Fort Drum and the following soil/ground characteristics, based on a 2005 study at the airfield, were used in the calculations. Although these characteristics are sufficient to generate preliminary project recommendations, soil characteristics likely vary throughout the base. Detailed soil testing of a specific site is necessary before actual project costs can be determined.

$\checkmark$ Soil thermal diffusivity: $0.02 \mathrm{ft}^{2} / \mathrm{hr}$

$\checkmark$ Water level: $75 \mathrm{ft}$

$\checkmark$ Overburden depth: $100 \mathrm{ft}$

$\checkmark$ Thermal conductivity: $1.3 \mathrm{Btu} / \mathrm{hr} \cdot \mathrm{ft} \cdot{ }^{\circ} \mathrm{F}$ 
The model does not consider site limitations, such as land area or water source availability (for closed and open loops, respectively). The assumption is that there are sufficient thermal sources/sinks in place. There is particular concern at Fort Drum about the risk of ground contamination with open-loop systems. Open-loop systems were analyzed and the results are presented in this report, but it is unlikely that they will be installed because of these concerns.

Table D-1: Building Groups Analyzed in FEDS for GSHPs

\begin{tabular}{|c|c|c|c|c|c|}
\hline \multirow[b]{2}{*}{$\begin{array}{c}\text { Group } \\
\text { ID }\end{array}$} & \multicolumn{4}{|c|}{ Building Group Description } & \multirow[b]{2}{*}{$\begin{array}{l}\text { Example } \\
\text { Building }\end{array}$} \\
\hline & Use Type & $\begin{array}{l}\text { Average } \\
\text { Size, } \mathbf{f t}^{2}\end{array}$ & $\begin{array}{l}\text { Average } \\
\text { Vintage }\end{array}$ & $\begin{array}{l}\text { Number of } \\
\text { Buildings } \\
\text { Represented }\end{array}$ & \\
\hline $10 \mathrm{a}$ & Small WWII Administration & 1,943 & 1941 & 146 & 85 \\
\hline $10 \mathrm{~b}$ & Medium/Large WWII Administration & 5,835 & 1941 & 56 & 4000 \\
\hline $10 \mathrm{~d}$ & Small Mid-aged Administration & 5,485 & 1990 & 64 & 10630 \\
\hline $10 \mathrm{e}$ & Large Mid-aged Administration & 40,154 & 1993 & 6 & 2065 \\
\hline 21 & Medical, Dental, Veterinarian & 14,168 & 1980 & 13 & 36 \\
\hline 23 & Simulator/Electronics & 4,423 & 1967 & 21 & 682 \\
\hline 30a & Army Lodging & 5,056 & 1941 & 28 & 2201 \\
\hline $30 \mathrm{~b}$ & WWII Barracks & 5,072 & 1941 & 52 & 521 \\
\hline $30 c+30 d$ & Large Mid-aged Barracks & 51,017 & 1988 & 33 & 10632 \\
\hline $30 \mathrm{e}$ & WWII Annual Training Barracks & 4,751 & 1941 & 75 & 552 \\
\hline $40 \mathrm{a}$ & Unconditioned Storage & 575 & 1977 & 56 & 2760 \\
\hline 40b & WWII Storage & 4,287 & 1941 & 52 & 89 \\
\hline 40c & Small Mid-aged Storage & 2,937 & 1985 & 53 & 23022 \\
\hline 40d & Large Mid-aged Storage & 27,296 & 1994 & 10 & 2055 \\
\hline $50 a$ & WWII Maintenance & 4,025 & 1941 & 36 & 1143 \\
\hline $50 \mathrm{~b}$ & Small Mid-aged Maintenance & 1,755 & 1979 & 55 & 1955 \\
\hline $50 c-1$ & Large Mid-aged Maintenance (High Bay) & 23,857 & 1987 & 18 & 10670 \\
\hline $50 c-2$ & Large Mid-aged Maintenance (Admin) & 10,224 & 1987 & 18 & 10670 \\
\hline 50d-1 & Aircraft Maintenance (Hangar) & 33,009 & 1986 & 6 & 2060 \\
\hline $50 \mathrm{~d}-2$ & Aircraft Maintenance (Admin) & 17,774 & 1986 & 6 & 2060 \\
\hline $60 \mathrm{a}$ & WWII Dining & 2,571 & 1941 & 21 & 640 \\
\hline $60 \mathrm{~b}$ & Large New Dining & 14,561 & 1989 & 6 & 10650 \\
\hline $60 \mathrm{c}$ & Security & 9,428 & 1976 & 6 & 10710 \\
\hline $80 \mathrm{a}$ & Separate Toilet/Shower & 891 & 1975 & 7 & 23051 \\
\hline $80 \mathrm{~b}$ & MWR & 12,378 & 1981 & 20 & 4325 \\
\hline $80 \mathrm{c}$ & Physical Fitness and Rec Centers & 19,065 & 1987 & 9 & 4305 \\
\hline
\end{tabular}


Table D-2: Buildings Analyzed in FEDS for GSHPs*

\begin{tabular}{||l|c|c||}
\hline \multicolumn{1}{|c|}{ Description } & Group ID & Building Numbers \\
\hline Medium/Large WWII Administration & $10 \mathrm{~b}$ & 543,2220 \\
\hline Large Mid-aged Administration & $10 \mathrm{e}$ & $174,4300,10000$ \\
\hline Medical, Dental, Veterinarian & 21 & 2443, 2416, 37, 10506, 10205, 36, 11050, 55 \\
\hline
\end{tabular}

* Building groups with no economically feasible projects are not included in this list.

For the recently constructed buildings, the following characteristics were used to represent typical administrative buildings and barracks found on an Army site.

- Size
o $100,000 \mathrm{ft}^{2}$ (large)
o $10,000 \mathrm{ft}^{2}$ (medium)
O $500 \mathrm{ft}^{2}$ (small)

- Vintage (this affects many model assumptions, including the levels of insulation) o 2,000 (new)

- Heating type

o Gas boiler with air handling units (AHU)

o Gas boiler with fan coil units (FCU)

o Gas furnace

o Air-source heat pump (ASHP)

- Cooling type

o Chiller with air handling units

o Chiller with fan coil units

o Package air conditioning direct exchange (AC/DX) unit

o Window / wall unit

o Air-source heat pump.

The building characteristics described above represent a significant number of new buildings found on an Army site and should adequately account for any recently constructed buildings that are of primary retrofit interest.

\section{Ground Source Heat Pump Resource Characterization}

GSHP assessments using FEDS have been completed at many sites in the past using the same analytic approach. The results developed here agree with previous findings. In general, conditions favoring replacement of existing heating and cooling systems with GSHPs include: 
$\checkmark$ Replacing old equipment. Equipment at the end of its useful life that will soon be replaced provides further economic incentive for GSHP installations, particularly if existing ductwork can be reused.

$\checkmark \quad$ More extreme climates. Cold winters, hot summers, or large daily temperature swings allow GSHPs to operate more efficiently than other electric cooling and heating systems. The cost of heating operation is comparable to non-electric heating systems.

$\checkmark$ High cost of non-electric fuels. If electricity is less than approximately 3.5 times as expensive per Btu than other fuels, GSHPs will generally be cost-effective. If no other fuel option is available and electric costs are high, GSHPs will be less expensive to operate than air-source heat pumps.

GSHPs are often not cost-effective in a building that:

$\checkmark$ Does not have both cooling and heating. A building needs to be both heated and cooled to take advantage of the GSHP efficiency in both modes. However, most of the savings are realized in the heating mode, so buildings with no cooling can still benefit from GSHPs.

$\checkmark$ Does not currently have ductwork. Installing a new air distribution system in addition to the conditioning equipment generally adds too much cost for a GSHP retrofit, unless the building is modified to allow zone-level heat pumps to be used in conjunction with a water loop, connecting the terminal units to a shared ground loop.

$\checkmark$ Is newer. Newer buildings (less than about 4 years old) generally have fairly efficient equipment (or at least the performance has not yet degraded significantly). As a result, premature replacement with a GSHP is generally uneconomic. In addition, the building envelope tends to be better, lengthening payback duration.

$\checkmark$ Is located in a mild climate. Buildings in fairly mild climates don't have the temperature extremes that make the ground loop important. A standard air-source heat pump would probably suffice.

$\checkmark \quad$ Uses an air-source heat pump. An air-source heat pump has many of the benefits of a GSHP except in extreme temperature conditions. These extreme temperature conditions often are not enough to justify replacement.

$\checkmark \quad$ Is connected to a central energy plant (unless the CEP will be abandoned). Although we often consider central energy systems as big energy wasters, on a building-by-building basis (which doesn't account for distribution losses) it's difficult to justify replacement. Centralized chiller plants can use larger, more efficient water-cooled units and can stage several chillers to run closer to full load (most efficient mode).

\section{Ground Source Heat Pumps: Economic and Other Analysis Parameters}

FEDS allows two primary financing options: appropriated funding through the Energy Conservation Investment Program (ECIP), and alternative financing, either a Utility Energy 
Services Contract (UESC) or an Energy Saving Performance Contract (ESPC). The parameters for alternative financing can be adjusted to match the options available to the site. For this assessment, a project life of 25 years and a third-party interest rate of 5\% were used.

FEDS uses the site electric rate schedule and energy costs to determine fuel costs and savings for GSHP retrofits. The entire rate schedule is used so that consumption and demand can be calculated on a time-of-use basis. Fossil fuel prices were determined using FY 2009 Army Energy and Water Reporting System (AEWRS) data. The following energy costs were used for the analysis:

- Electricity: 7.54\$/kWh (\$22.10/MMBtu) and $\$ 6.75 / \mathrm{kW}$

- Natural Gas: \$0.877/therm

- Propane: \$1.67/gallon.

The average GSHP system costs per square foot in buildings constructed before 2002 that were found to be cost-effective are as follows:

- Open loop: $\$ 2.78 / \mathrm{ft}^{2}$

- Horizontal closed loop: $\$ 8.29 / \mathrm{ft}^{2}$

- Vertical closed loop: $\$ 12.53 / \mathrm{ft}^{2}$.

Note that these costs should be used only as rough reference for the buildings modeled in this analysis because heating and cooling loads (on a per square foot basis) can vary drastically between buildings. The difference in costs between GSHP types reflects economies of scale working in favor of larger projects. Where fewer or smaller units are being installed, the price increases comparatively with a similar technology.

For recently constructed buildings in the generic analysis, typical installed costs are shown below. Again, these costs only apply to buildings that were found to be cost-effective. Newer buildings tend to have smaller heating and cooling loads on a square foot basis. Lower heating and cooling loads also reduce the cost of GSHP systems. In addition, the buildings from the generic set tend to be much larger than the pre-2002 buildings that were found to be costeffective, and larger buildings often have lower heating and cooling capacities per square foot, resulting in lower GSHP system costs per square foot.

- Open loop: $\$ 0.90 / \mathrm{ft} 2$

- Horizontal closed loop: $\$ 4.44 / \mathrm{ft}^{2}$

- Vertical closed loop: $\$ 6.24 / \mathrm{ft}^{2}$

Findings: Ground Source Heat Pumps

GSHPs were found to be economic in some situations at Fort Drum. GSHPs were only found to be cost-effective for a few building groups that were constructed before 2002. In general, buildings need to be air-conditioned to have cost-effective GSHP projects, and air conditioning is not installed in all buildings at Fort Drum. Projects were identified for newer buildings with 
natural gas and electric package air conditioning units. For all buildings, both new and old, open-loop systems were found to be the most cost-effective, followed by horizontal and then vertical. Fort Drum should reconsider open-loop systems if implementing GSHPs is a high priority and open-loop systems do not violate any regulations.

Table D-3 presents the simple payback values for pre-2002 Fort Drum buildings. The values shown are the average for all buildings with economic projects within that group. Some of the building groups in Table D-3 contain buildings served by different fuels or with other noteworthy differences. To find the economic characteristics for buildings with specific heating and cooling technologies within a group, see Appendix D-1, which contains the economic results for each building examined.

Table D-3: Simple Payback Period for Building Groups Analyzed in FEDS for GSHPs

\begin{tabular}{|c|c|c|c|c|c|c|c|}
\hline \multirow{2}{*}{ Description* } & \multirow{2}{*}{$\begin{array}{l}\text { Group } \\
\text { ID }\end{array}$} & \multicolumn{3}{|c|}{ UESC/ESPC Financing } & \multicolumn{3}{|c|}{ ECIP Financing } \\
\hline & & Open** & Horz† & Vert†† & Open & Horz & Vert \\
\hline $\begin{array}{l}\text { Medium/Large WWII } \\
\text { Administration }\end{array}$ & $10 \mathrm{~b}$ & 6.4 & 16.0 & - & 6.1 & 13.6 & 16.2 \\
\hline Large Mid-aged Administration & $10 \mathrm{e}$ & - & - & - & 10.5 & - & - \\
\hline Medical, Dental, Veterinarian & 21 & - & - & - & 11.1 & - & - \\
\hline
\end{tabular}

* Building groups with no economically feasible projects are not included in this list

** Open-loop GSHP

$\dagger$ Horizontal closed-loop GSHP

†† Vertical closed-loop GSHP

FEDS findings using ECIP funding for the various technology combinations in the typical, recently-constructed buildings are shown below by GSHP configuration and building type. All of the analyzed heating and cooling technology combinations are shown in Table D-4 column and row headings. Empty cells indicate GSHPs are not cost-effective for any building type analyzed for that technology combination. Administration buildings are indicated with "(A)"; barracks are indicated with "(B)." When neither is indicated, the retrofit is cost-effective for both. At Fort Drum, GSHPs tend to be cost-effective across a range of building types and uses. 
Table D-4: GSHP Opportunities Using ECIP Funding for Post-2002 Constructed Buildings

\begin{tabular}{||c||c|c|c|c|c||}
\hline & $\begin{array}{c}\text { Air-Cooled } \\
\text { Chiller }\end{array}$ & $\begin{array}{c}\text { Package } \\
\text { AC/DX Units }\end{array}$ & $\begin{array}{c}\text { Window / } \\
\text { Wall Units }\end{array}$ & $\begin{array}{c}\text { Central } \\
\text { Chilled } \\
\text { Water }\end{array}$ & $\begin{array}{c}\text { Air-Source Heat } \\
\text { Pump }\end{array}$ \\
\hline \hline $\begin{array}{c}\text { Gas Boiler / Air } \\
\text { Handling Unit }\end{array}$ & $\begin{array}{c}\text { Open-Loop } \\
\text { Horizontal } \\
\text { Vertical }\end{array}$ & Horizontal (B) & Horizontal (B) & & \\
\hline $\begin{array}{c}\text { Gas Boiler / Fan Coil } \\
\text { Unit }\end{array}$ & & Horizontal (B) & & & \\
\hline Gas Furnace & $\begin{array}{c}\text { Open-Loop (B) } \\
\text { Horizontal } \\
\text { Vertical }\end{array}$ & & & & Open-Loop (B) \\
\hline Air-Source Heat Pump & \multicolumn{1}{|c|}{} & & & & \\
\hline
\end{tabular}

Empty cells are not cost-effective

With ECIP funding, open-loop and horizontal closed-loop systems were found to be costeffective most often. Smaller buildings were primarily the economic opportunities found, with some medium and large barracks as well (although only for open-loop systems). Overall, simple payback periods range from 3.1 to 14.1 years for barracks and 5.1 to 14.6 years for administration buildings. GSHP projects replacing air-cooled chillers tend to have much better economics than projects in buildings with other cooling technologies.

With alternative financed projects, the capital cost is increased, so only large barracks currently using ASHPs are cost-effective for open-loop GSHP retrofits. The payback would be 8.2 years. No other financed options are cost-effective at this time.

Fort Drum does not have an ideal climate for GSHPs because of the dominant heating season, but these results show there are some opportunities for retrofits. To provide additional opportunities, the imbalance between heating and cooling loads could be mitigated by selecting large buildings with high internal heat gains or by using hybrid GSHP-boiler systems to reduce the heating load on the GSHP.

\section{Additional Ground Source Heat Pump Analysis: Three Options}

PNNL also conducted additional analysis at the request of Fort Drum on the life-cycle cost of new barracks using GSHPs. Fort Drum currently has hybrid GSHP-boiler systems installed in all the new barracks. Three heating and cooling technology combinations were analyzed as a review of this concept: 1) GSHP only; 2) hybrid GSHP-boiler; and 3) boiler and chiller.

Building details were collected during the PNNL visit to Fort Drum, and the three scenarios were modeled in FEDS to compare energy consumption and costs. Cost data was collected from FEDS, RS Means, and manufacturers. Other economic values were chosen based on standard Army and industry practices. 
The hybrid GSHP-boiler system scenario is based on barracks Building P-785, on which construction was recently completed in the spring of 2010. It is a three-story barracks with $88,152 \mathrm{sf}$ of heated and cooled space. The boiler system consists of two KN-20 Hydrotherm condensing boilers for peak-load heating and domestic hot water and four Multistack GSHPs for base-load heating and cooling. The two other technology combinations were analyzed using the same building details and heating and cooling loads. The equipment was found to have, or was assumed to have, the characteristics described in Table D-5.

Table D-5. Characteristics of Modeled Systems

\begin{tabular}{|c|c|c|c|c|}
\hline \multicolumn{2}{|c|}{$\begin{array}{c}\text { Technology } \\
\text { Combination }\end{array}$} & \multirow{2}{*}{$\begin{array}{l}\text { FEDS-Recommended } \\
\text { Equipment Sizing } \\
60 \text { tons }\end{array}$} & \multirow{2}{*}{$\begin{array}{c}\begin{array}{c}\text { Installed/Oversized } \\
\text { Equipment Sizing }\end{array} \\
128 \text { tons }\end{array}$} & \multirow{2}{*}{$\begin{array}{c}\text { Rated Efficiency } \\
5.98 \mathrm{COP}\end{array}$} \\
\hline \multirow{3}{*}{ GSHP } & Cooling & & & \\
\hline & Heating & $0.69 \mathrm{MMBtu} / \mathrm{hr}$ & 1.49 MMBtu/hr & $2.7 \mathrm{COP}$ \\
\hline & $\begin{array}{l}\text { Hot Water } \\
\text { Heater }\end{array}$ & $0.18 \mathrm{MMBtu} / \mathrm{hr}$ & $0.36 \mathrm{MMBtu} / \mathrm{hr}$ & $85 \%$ \\
\hline \multirow{2}{*}{ Hybrid } & GSHP & 60 tons & 128 tons & $\begin{array}{l}\text { 20.4 EER (cooling), } \\
\text { 2.7 COP (heating) }\end{array}$ \\
\hline & Boiler & 1.15 MMBtu/hr & 3.4 MMBtu/hr & $88 \%$ \\
\hline \multirow{2}{*}{$\begin{array}{l}\text { Boiler- } \\
\text { Chiller }\end{array}$} & Chiller & 60 tons & 128 tons & $2.46 \mathrm{COP}$ \\
\hline & Boiler & $1.84 \mathrm{MMBtu} / \mathrm{hr}$ & 4.89 MMBtu/hr & $88 \%$ \\
\hline
\end{tabular}

FEDS was used to calculate heating and cooling loads, energy consumption, and some costs for the three cases. Domestic water heating equipment was also included, because the boiler used for space heating also heats domestic hot water.

Two scenarios were evaluated for each technology combination: 1) equipment sized to meet the building loads calculated by FEDS, and 2) equipment sized to match what is currently installed in the new barracks. The results are similar, but at different scales.

The analysis shows that, over a 30-year project lifetime, the boiler-chiller system is the most lifecycle cost-effective. This is primarily because of Fort Drum's high cost of electricity and relatively low cost of natural gas, as well as the relatively low heating coefficient of performance (COP) of the installed GSHP. If the cost of natural gas increased to \$1.15/therm (instead of $\$ 0.88 /$ therm), the hybrid GSHP-boiler system would be the most economic option. Similarly, if the heating COP of the GSHP were 4.0 instead of 2.7, the hybrid GSHP-boiler system would be the most economic option. The GSHP-only option is the least economic of the three options.

Sized to meet the building loads as calculated by FEDS, the capital cost for the hybrid GSHPboiler system was $\$ 205,206$ more expensive than the boiler-chiller system. The energy saved by using the hybrid GSHP-boiler system was $403 \mathrm{MMBtu} /$ year and \$3,351/year. Over a 30-year lifetime, $\$ 104,804$ would be saved in energy costs, $\$ 37,509$ would be saved in O\&M costs, and 
$\$ 27,891$ would be saved in equipment replacement costs. However, this still results in a lifecycle cost that is $\$ 35,001$ more for the hybrid system compared to the boiler-chiller system.

As noted above, the analysis is highly dependent on energy rates. Fort Drum has enjoyed low natural gas rates since September 2008. The average natural gas rate for the past 2 years has been about $\$ 0.62 /$ therm. The rates have been low primarily because of the national economic slowdown and a surplus of available natural gas. Prior to the economic slowdown, from July 2004 to August 2008, the average rate of natural gas at Fort Drum was $\$ 1.125 /$ therm. The rate for 22 months of this 50-month time period was over \$1.00/therm. For 16 months, the rate was over $\$ 1.15 /$ therm.

For the long-term, it is wise for Fort Drum to invest in the option that has that lowest energy input (highest energy efficiency) and uses the least amount of fossil fuel. Natural gas rates will likely rise again during an improvement in the economy, a severe winter, or a shortage (real or contrived) of natural gas. Furthermore, the Energy Independence and Security Act (EISA) requires new buildings and major renovations to reduce and eventually eliminate use of fossil fuels. Therefore, while the boiler-chiller option appears to be the best choice with current economic conditions, Fort Drum would make a better long-term investment and work toward meeting Federal legislation with the hybrid GSHP-boiler option presently in use.

\section{Ground Source Heat Pumps: Next Steps}

Fort Drum should consider the presented results and choose buildings to investigate in more detail for GSHP project potential. Depending on the needs of the funding source (i.e., ECIP projects should be at least $\$ 750,000$ in capital cost), the results above should be compared to potential buildings with sufficient space for the GSHP underground components.

For buildings constructed before 2002, use Tables D-2 and D-3 to identify buildings with appropriate conditions. For more recently constructed buildings, use the generic results presented in Table D-4 to identify projects. Where there are similarities between recently constructed buildings and generic buildings deemed cost-effective, detailed building and surrounding land area information should be collected to evaluate specific project feasibility. Buildings constructed after 2002 that are not administrative or barracks can be considered administrative for the purposes of this preliminary assessment, because most other buildings on site will have occupancies similar to that of administrative buildings.

Once buildings have been selected, FEDS could be used to more accurately calculate costs and energy savings for recently constructed buildings, and develop a list of buildings where projects should be developed. These buildings can then be put into a project proposal, and experienced designers in the area can be contacted to develop detailed project designs.

Conduct soil tests during site excavation for any new construction on site. Precise buildingspecific soil characteristics will be necessary for actual project design. Also, if certain parts of the Fort Drum site are found to have superior soil for GSHPs, additional cost-effective projects may be identified. 
When constructing new buildings, consider the long-term economic, environmental, and goalmeeting benefits of a hybrid GSHP-boiler system compared to the short-term economic benefits of a boiler-chiller system.

\section{Ground Source Heat Pump Sources of Information}

FEMP - Federal Energy Management Program. 2001. Federal Technology Alert: Ground Source Heat Pumps Applied to Federal Facilities - Second Edition. DOE/EE-0245, Federal Energy Management Program, U.S. Department of Energy, Washington, DC. Accessed May 2010 at http://www1.eere.energy.gov/femp/pdfs/FTA_gshp.pdf.

Goetzler W, R Zogg, H Lisle, and J Burgos. 2009. Ground Source Heat Pumps: Overview of Market Status, Barriers to Adoption, and Options for Overcoming Barriers. Prepared by Navigant Consulting, Inc. for the U.S. Department of Energy, Energy Efficiency and Renewable Energy Geothermal Technologies Program, Washington, DC. Accessed May 2010 at http://www1.eere.energy.gov/geothermal/pdfs/gshp_overview.pdf.

Hughes P. 2008. Geothermal (Ground-Source) Heat Pumps: Market Status, Barriers to Adoption, and Actions to Overcome Barriers. ORNL/TM-2008/232, Energy and Transportation Science Division, Oak Ridge National Laboratory, Oak Ridge, TN. Accessed May 2010 at http://www1.eere.energy.gov/geothermal/pdfs/ornl_ghp_study.pdf. 


\section{Appendix D-1: Detailed GSHP Economic Results}

Appendix D-1 presents the estimated simple payback period, savings to investment ratio, and installed capital cost for each GSHP project that was found to be cost-effective in pre-2002 buildings on Fort Drum. The economic results vary based on the type of building, current heating and cooling technologies, and the funding source.

\begin{tabular}{|c|c|c|c|c|c|c|c|}
\hline $\begin{array}{l}\text { Funding } \\
\text { Source }\end{array}$ & Description & $\begin{array}{l}\text { Group } \\
\text { ID }\end{array}$ & $\begin{array}{c}\text { Current Heating/Cooling } \\
\text { Technology }\end{array}$ & Retrofit Technology & $\begin{array}{c}\text { Payback } \\
\text { Period, } \\
\text { years }\end{array}$ & $\begin{array}{c}\text { Savings to } \\
\text { Investment } \\
\text { Ratio }\end{array}$ & $\begin{array}{c}\text { Installed } \\
\text { Capital } \\
\text { Cost }\end{array}$ \\
\hline ECIP & Medical, Dental, Veterinarian & 21 & $\begin{array}{c}\text { Natural Gas Conventional Boiler / } \\
\text { Electric Package Unit }\end{array}$ & Open-Loop GSHP & 11.1 & 1.4 & $\$ 354,980$ \\
\hline UESC & Medium/Large WWII Administration & $10 \mathrm{~b}$ & $\begin{array}{c}\text { Propane Conventional Furnace / } \\
\text { Electric Package Unit }\end{array}$ & $\begin{array}{c}\text { Horizontal Closed-Loop } \\
\text { GSHP }\end{array}$ & 16.0 & 1.3 & $\$ 143,185$ \\
\hline ECIP & Medium/Large WWII Administration & $10 \mathrm{~b}$ & $\begin{array}{c}\text { Propane Conventional Furnace / } \\
\text { Electric Package Unit }\end{array}$ & $\begin{array}{c}\text { Horizontal Closed-Loop } \\
\text { GSHP }\end{array}$ & 13.6 & 1.8 & $\$ 143,185$ \\
\hline UESC & Medium/Large WWII Administration & $10 \mathrm{~b}$ & $\begin{array}{c}\text { Propane Conventional Furnace / } \\
\text { Electric Package Unit }\end{array}$ & Open-Loop GSHP & 6.4 & 2.9 & $\$ 67,133$ \\
\hline ECIP & Medium/Large WWII Administration & $10 \mathrm{~b}$ & $\begin{array}{c}\text { Propane Conventional Furnace / } \\
\text { Electric Package Unit }\end{array}$ & Open-Loop GSHP & 6.1 & 3.7 & $\$ 75,877$ \\
\hline ECIP & Medium/Large WWII Administration & $10 \mathrm{~b}$ & $\begin{array}{c}\text { Propane Conventional Furnace / } \\
\text { Electric Package Unit }\end{array}$ & $\begin{array}{l}\text { Vertical Closed-Loop } \\
\text { GSHP }\end{array}$ & 16.2 & 1.4 & $\$ 189,160$ \\
\hline ECIP & Large Mid-aged Administration & $10 \mathrm{e}$ & $\begin{array}{c}\text { Natural Gas Conventional Boiler / } \\
\text { Electric Package Unit }\end{array}$ & Open-Loop GSHP & 10.5 & 1.4 & $\$ 91,711$ \\
\hline
\end{tabular}


APPENDIX E

Analysis of Solar Opportunities 



\section{Appendix E: Analysis of Solar Opportunities}

\section{Solar Technology}

There is a wide range of solar technologies and applications available for energy generation. Solar technologies can be classified by the specific technique used for converting solar energy into useful energy. Solar energy is unique in that the sun's energy, or insolation, can be captured to provide electrical energy, heating energy (solar thermal), or a combination of both.

Solar technologies can be further categorized by their scale. Large-scale solar projects can easily exceed $1 \mathrm{MW}$ and can have hundreds of collectors. Smaller-scale projects, often at the building level, are also possible and may be more desirable because of land area limitations, aesthetics considerations, or for energy security. Certain solar technologies, such as photovoltaic (PV), can be either large-scale or small-scale, while technologies such as solar hot water heating are only found at the building level.

\section{Solar Electric}

Solar electric collectors are either PV arrays or concentrating solar arrays. There are three major PV array subcategories, as follows:

- Flat Panel. Arrays of PV modules mounted on racks either at ground level or on rooftops at a fixed angle. Generally, this angle is equal to the location's latitude. On rooftops, the angle can be the angle of the rooftop or an angle set by specialized mounting brackets attached to the roof. In addition, there are two common PV technologies on the market, silicon PV and cadmium telluride (CdTe) "thin film” PV. Other PV technologies such as gallium arsenide (GaAs) and copper-indium selenide (CIGS) are available, but uncommon.

- Axis-Tracking. PV arrays can be mounted on an assembly that moves throughout the day to keep the array positioned at an optimum angle to maximize the captured sunlight (Figure E-1). An axis-tracking system can be either single- or dual-axis in nature. A single-axis tracking system typically has a fixed tilt and the system follows the sun's trajectory across the sky. These systems are able to collect more sunlight than nontracking systems. A dual-axis tracking system allows the panels to rotate along two axes, thereby truly maximizing the panel's ability to harvest solar energy. However, these systems are considerably more complex and impose additional operations and maintenance $(\mathrm{O} \& \mathrm{M})$ costs than flat panel assemblies. 


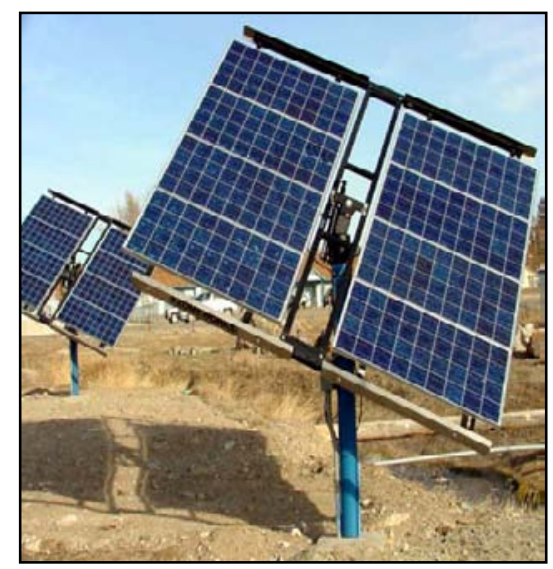

Figure E-1: Axis-Tracking PV Array

Concentrating solar power (CSP) systems use mirrors, lenses, and other optical devices to concentrate the sun's energy. There are four primary configurations of thermal CSP systems:

- Solar Dish. A solar dish system employs an engine that is able to harvest thermal energy to generate electricity. These dual-axis tracking systems use dish-like concentrators to focus thermal energy on a point where a heat engine is mounted. Stirling engines are frequently used in solar dish applications. Most systems are several kilowatts to tens of kilowatts in size.

- Solar Power Tower. A solar power tower system uses very large arrays of mirrors, or heliostats, to concentrate the sun's energy on a central receiver tower to produce steam that drives a generator. Thermal storage allows the system to store thermal energy for use at dusk and into the evening. Most existing or planned commercial solar power tower plants are larger than $10 \mathrm{MW}$.

- Solar Trough. When used for power generation, these large arrays concentrate the sun's energy onto a pipe containing a liquid that is used to generate steam that drives a generator. These systems always employ single-axis tracking mirrors or reflectors orientated along the north-south axis and are highly sensitive to the slope of the ground as a result of the need to pump the liquid through the collector tubes. Cogeneration and thermal storage are options for this technology as well. Solar trough plants are $40 \mathrm{MW}$ or larger.

- Concentrating PV. In a CPV system, mirrors and/or lenses focus sunlight onto a small area of PV material. Typically, this PV material is more sophisticated and expensive than the PV material used in conventional solar cells. However, these advanced PV cells are also more efficient and are capable of absorbing insolation levels equivalent to dozens to hundreds of suns. While there are several commercial, smallscale CPV arrays and a handful of medium-scale utility demonstration projects, this technology is still too immature to be considered in this analysis.

Thermal CSP plants are still in various stages of development. While thermal CSP plants are somewhat unproven compared to traditional PV plants, they have the potential to deliver large quantities of energy at competitive prices. 
Thermal concentrating power systems were not considered for this assessment because the available direct normal insolation is less than the $6.75 \mathrm{kWh} / \mathrm{m}^{2} /$ day threshold typically cited for CSP feasibility (DOE 2010). Direct normal insolation is a subset of the total insolation levels that excludes the indirect (diffuse) insolation, which is reflected from clouds or the ground, because this insolation cannot be concentrated. Fort Drum has an average direct normal insolation level of $4.03 \mathrm{kWh} / \mathrm{m}^{2} /$ day (NASA 2010), which is below the $6.75 \mathrm{kWh} / \mathrm{m}^{2} /$ day target.

\section{Solar Thermal}

Rather than electricity as the end product, solar energy can also be used to directly heat air in the form of transpired solar collectors (i.e., solar walls), water that is used for space heating, or water that is used for service hot water (SHW) or swimming pools. These solar energy systems can be cost-competitive even when PV is not. However, solar thermal projects do not count towards the EPAct mandate and therefore are excluded from this analysis.

\section{Solar Analysis Approach}

The analytic approach for the solar energy assessment consists of the following steps:

$\checkmark \quad$ Identify solar potential-Use established sources to determine seasonal and annual solar radiation for the site.

$\checkmark$ Determine utility perspective-Obtain electric rate tariff information, evaluate state and local regulations, and identify grants, incentives, and other support.

$\checkmark \quad$ Identify potential development areas - Study existing electrical transmission system and identify installation-specific sites and potential users of generated energy.

$\checkmark$ Determine applicable solar technology - Evaluate solar electric technologies including both large-scale (approximately 1+ MW) applications, such as a ground-mounted PV array, and small-scale (kW-scale) applications, such as roof-mounted PV systems.

$\checkmark$ Develop project economics_-Determine project capital investment requirements, project O\&M costs, and estimate economic value of expected electric production based on selected solar technology and market prices.

In addition to the large-scale PV arrays, this assessment also examined a small-scale PV array for the off-grid Non-Commissioned Officers (NCO) Academy site per Fort Drum's request. The PV array for the NCO Academy could displace electricity produced by two 35-kW propane generators that are typically loaded at $20 \%$ of their nameplate capacities. This translates to an average load of $14 \mathrm{~kW}$. Consequently, the solar PV feasibility study evaluated a 14-kW PV array for the NCO Academy site.

The 14-kW solar PV system may produce more energy than is needed at the NCO Academy site because of the site's intermittent use, or it may not produce enough or any energy while the site is being used if the coincident solar energy is insufficient. 
To account for this mismatch in supply and load, Fort Drum could install a battery storage system. Flooded lead-acid batteries, the most common energy storage choice for PV applications, cost approximately $\$ 150 / \mathrm{kWh}$. Valve-regulated lead acid (VRLA) batteries are becoming common as well and cost $\$ 200 / \mathrm{kWh}$. Sodium sulfur (NaS) batteries, typically used for utility-scale grid-integrated renewable energy support, cost approximately $\$ 450 / \mathrm{kWh}$ (Ton et al. 2008).

Beyond the assumptions used to arrive at the 14-kW size estimate, additional information, such as an estimated site load profile and how many days of storage the battery system should supply, is required to properly size and price a battery system for the site. Ultimately, including the cost of a battery system in the economic analysis will drive the cost of energy of the solar PV project higher.

Another approach would be to operate the solar PV system in conjunction with the propane generators, rather than as a replacement for them. Instead of a battery storage system, the propane generators could be the backup power to the solar PV system. This would reduce capital costs, but would also reduce the amount of solar energy consumed (i.e., fossil fuel energy replaced) because of the site's intermittent use. There would be instances when the PV panels are producing electricity, but the site is not in use. Neither option (solar PV with battery system or solar PV with propane generators) is clearly the better economic choice; a detailed analysis would be required to determine that.

\section{Solar Resource Characterization}

The Northeast region of the United States experiences insolation levels ranging between 3.5 and $5.0 \mathrm{kWh} / \mathrm{m}^{2} /$ day. From a resource perspective, Fort Drum is positioned in a region of moderate solar potential. Figure E-2 displays the annual mean horizontal insolation on a south facing, latitude-tilted collector for the region. 


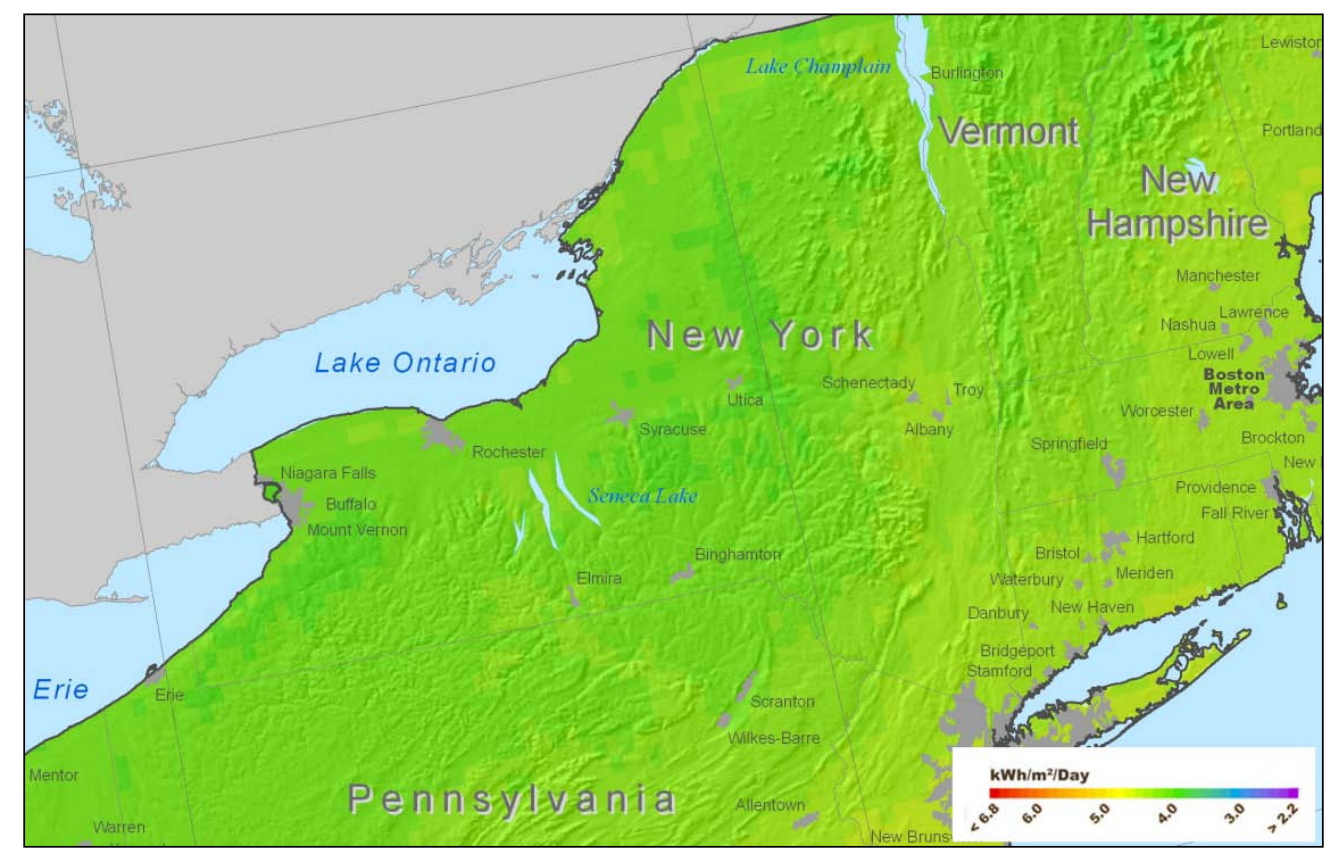

Figure E-2: Solar Insolation Levels (NREL 2008)

The solar resource potential was estimated using the solar potential estimates in National Aeronautics and Space Administration's (NASA) Surface meteorology and Solar Energy (SSE) data and Natural Resources Canada's RETScreen analysis software. The SSE data set is a continuous and consistent 10-year global climatology of insolation and meteorology data on a $1^{\circ}$ by $1^{\circ}$ grid system. Although the SSE data within a particular grid cell are not necessarily representative of a particular microclimate within the cell, the data are considered to be the average over the entire area of the cell. That estimate should be sufficiently accurate for preliminary feasibility studies of new renewable energy projects.

Table E-1 shows the average solar insolation data for several different surface orientations. Average monthly insolation values are provided in $\mathrm{kWh} / \mathrm{m}^{2} /$ day for the following conditions:

- Tilt 0 - Collector installed at a $0^{\circ}$ tilt (i.e., on a flat surface such as a roof).

- Tilt (lat-15) - A tilt of latitude minus $15^{\circ}$ would favor energy production in the summer when the sun is higher.

- Tilt lat - Tilting a PV array at an angle equal to the latitude is a generally accepted way to optimize annual electricity production.

- Tilt (lat+15) - A tilt of latitude plus $15^{\circ}$ would favor energy production in the winter when the sun is lower.

- Tilt 90 - Collector installed against a vertical surface (i.e., a wall).

- Single-Axis Tracking - A collector capable of tracking the sun's azimuth angle over the course of the day. 
Table E-1: Monthly Averaged Insolation Incident on a South-Facing Tilted Surface at Fort Drum (kWh/m²/day)

\begin{tabular}{||c|c|c|c|c|c|c|c|c|c|c|c|c|c||}
\hline & Jan & Feb & Mar & Apr & May & Jun & Jul & Aug & Sep & Oct & Nov & Dec & $\begin{array}{c}\text { Annual } \\
\text { Average }\end{array}$ \\
\hline Tilt 0 $^{\circ}$ & 1.6 & 2.4 & 3.4 & 4.6 & 5.5 & 6.1 & 6.0 & 5.2 & 4.0 & 2.7 & 1.6 & 1.3 & 3.7 \\
\hline Tilt 29 $^{\circ}$ & 2.7 & 3.4 & 4.1 & 4.9 & 5.5 & 5.8 & 5.9 & 5.4 & 4.6 & 3.5 & 2.4 & 2.1 & 4.2 \\
\hline Tilt 44 $^{\circ}$ & 3.1 & 3.8 & 4.3 & 4.8 & 5.1 & 5.3 & 5.4 & 5.1 & 4.5 & 3.7 & 2.6 & 2.5 & 4.2 \\
\hline Tilt 59 $^{\circ}$ & 3.3 & 3.9 & 4.1 & 4.4 & 4.5 & 4.6 & 4.7 & 4.6 & 4.3 & 3.7 & 2.7 & 2.7 & 4.0 \\
\hline Tilt 90 $^{\circ}$ & 3.3 & 3.7 & 3.3 & 3.0 & 2.8 & 2.7 & 2.8 & 3.0 & 3.2 & 3.1 & 2.4 & 2.7 & 3.0 \\
\hline $\begin{array}{c}\text { Single- } \\
\text { Axis } \\
\text { Tracking }\end{array}$ & 3.7 & 4.5 & 5.3 & 6.1 & 6.5 & 7.0 & 7.0 & 6.6 & 5.7 & 4.4 & 3.0 & 2.8 & 5.2 \\
\hline
\end{tabular}

As shown, a flat collector tilted at $44^{\circ}$ (the site's latitude) has an average yearly solar potential of $4.2 \mathrm{kWh}_{\text {solar }} / \mathrm{m}^{2} /$ day. A single-axis tracking PV array will receive $5.2 \mathrm{kWh}$ solar $/ \mathrm{m}^{2} /$ day of incident solar radiation. Figure E-3 shows this incident solar radiation on a flat roof surface ( $0^{\circ}$ tilt), a fixed array (latitude tilt), and a single-axis tracking array at Fort Drum.

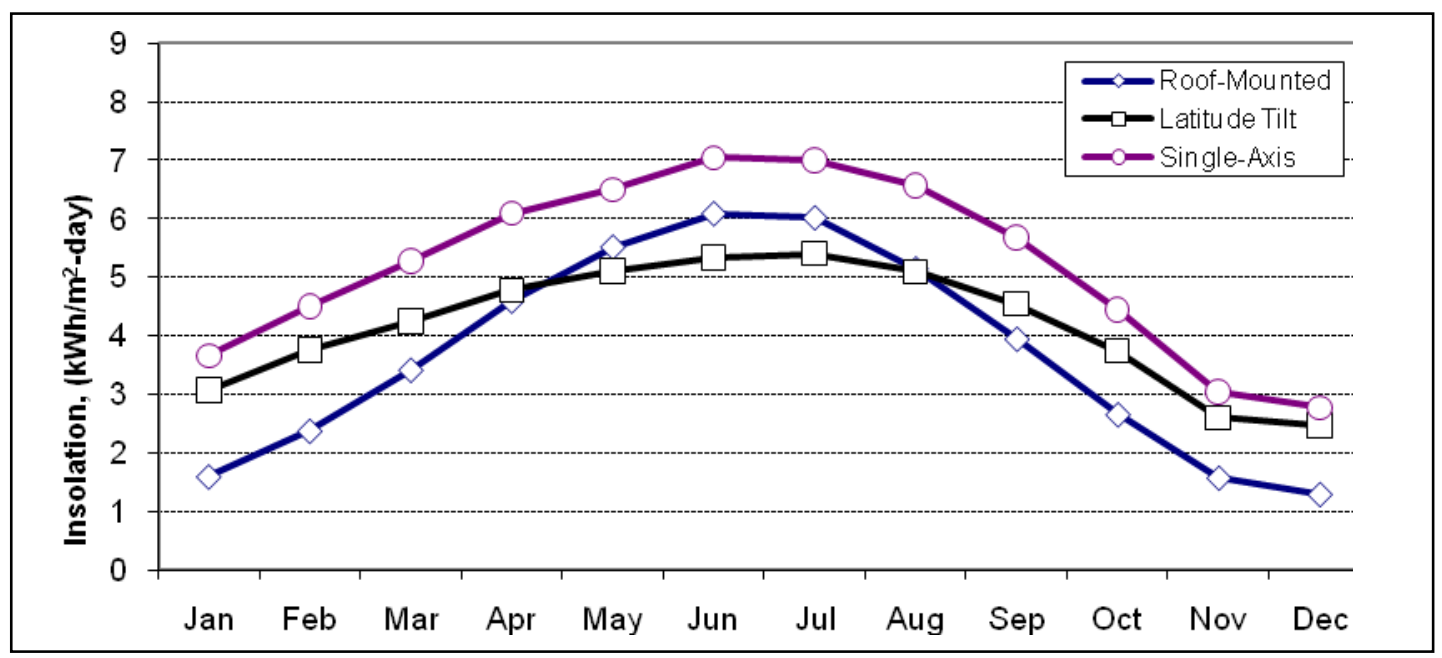

Figure E-3: Average Daily Insolation at Fort Drum

\section{Siting Considerations for PV Technologies}

Compared to most renewable energy technologies, PV panels have a fair degree of siting flexibility. As previously mentioned, an array can be mounted on the ground or upon existing buildings and structures. A potential site needs to be free of any objects, such as trees or buildings, which may cast a shadow on the array. Also, the system will require an inverter to convert the DC output power into AC power. For projects $25 \mathrm{~kW}$ or larger, it is common to use multiple inverters to optimize the system's efficiency as well as provide redundancy.

A typical 1-kW PV array may range in size from 8 to $9 \mathrm{~m}^{2}$; however, a larger array requires access space as well as spacing between the rows of panels to avoid self-shading, and will subsequently require a greater amount of space per installed kW. For example, a 30-kW array would likely require $550 \mathrm{~m}^{2}$, and a $100-\mathrm{kW}$ array may require nearly $2,000 \mathrm{~m}^{2}$, assuming that the PV array occupies $50 \%$ of the space. Panels mounted on slanted roofs can usually be more tightly grouped because of a decrease in self-shading potential. In addition, large arrays can 
produce considerable amounts of energy and require siting near existing high voltage power lines.

Fort Drum appears to have a moderate amount of open space for ground-mounted PV. Possible sites that appear to have sufficient open space and are relativity free from shading include:

- The empty field at the intersection of Enduring Freedom Road \& Tigris River Valley Road,

- The empty field south of Nash Road and east of Hospital Lane,

- The empty field south of Nash Road and west of Hospital Lane,

- The off-grid NCO Academy.

There are additional spaces spread throughout Fort Drum that might be suitable for a PV array. The terrain is generally flat, but is frequently heavily wooded. The primary disadvantage of these areas is the increased expense of land preparation for a PV array. The availability of space near the cantonment area suggests that considering more remote areas for large-scale PV deployment may not be necessary. Also, the Corps of Engineers is interested in including solar PV on new building rooftops.

The 14-kW PV array at the NCO Academy would be approximately $800 \mathrm{ft}^{2}$ in size; however, if this array is located on the ground and arranged into two, 7-kW strings, the array will require approximately 2,000 $\mathrm{ft}^{2}$ to avoid self-shading. Also, a small area needs to be reserved for an inverter and any potential battery banks.

\section{Findings: Solar Electric Production}

Solar conversion is an inefficient process; typical PV cells have a conversion efficiency ranging from $10 \%$ to $20 \%$. Taking into account the annual solar potential and the efficiency of a typical PV system, each fixed-angle, latitude-tilted MW of installed PV would be expected to produce $1,359 \mathrm{MWh}_{\text {electric }}$ at Fort Drum. The system would have a capacity factor of $15.5 \%$.

A single-axis tracking PV array can produce significantly more electricity than a stationary PV array, resulting in a higher output per unit surface area, and has a much flatter energy output profile during the day. The tracking racks increase the cost of installation by approximately $\$ 1$ to $\$ 2$ per installed watt. A 1-MW single-axis tracking array would produce 1,692 $\mathrm{MWh}_{\text {electric }}$ annually at Fort Drum. The system would have a capacity factor of $19.3 \%$.

A building-mounted PV array installed on a flat roof at Fort Drum would be expected to produce

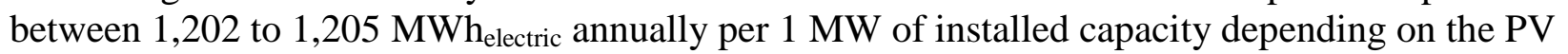
technology. The system would have a capacity factor of 13.7 to $13.8 \%$, depending on the PV technology.

A 14-kW latitude-tilted PV array located at the NCO Academy would be expected to produce $18,028 \mathrm{kWh}_{\text {electric }}$ per year. The system would have a capacity factor of $14.7 \%$. 
Satellite imagery shows that the five largest viable roofs on post have approximately 26,170 square meters of open roof area, which could host approximately 3,175 kW of integrated roofmembrane PV material, producing approximately 3,825 $\mathrm{MWh}_{\text {electric }}$ annually. These are listed in Table E-2.

It was assumed that only 50\% of the rooftop space would be available for CdTe thin film PV modules because of commonly encountered roof obstructions such as HVAC systems or vents, the need to preserve access paths across the roof, and shading from nearby buildings, trees, or parapet walls.

Table E-2: Roof-Integrated Membrane PV Analysis at Fort Drum

\begin{tabular}{|l|c|c|c||}
\hline $\begin{array}{c}\text { Building } \\
\text { Number }\end{array}$ & Roof Area, $\mathbf{~ m}^{\mathbf{2}}$ & $\begin{array}{c}\text { Potential Installed } \\
\text { Capacity, kW }\end{array}$ & $\begin{array}{c}\text { Energy Output, } \\
\text { MWh/yr }\end{array}$ \\
\hline $\begin{array}{c}6003,6005- \\
6013^{*}\end{array}$ & 9,720 & 1,200 & 1,446 \\
\hline 4530 & 7,889 & 950 & 1,145 \\
\hline 4525 & 4,370 & 525 & 633 \\
\hline 4900 & 3,267 & 390 & 470 \\
\hline 990 & 925 & 110 & 133 \\
\hline \hline Total & $\mathbf{2 6 , 1 7 1}$ & $\mathbf{3 , 1 7 5}$ & $\mathbf{3 , 8 2 6}$ \\
\hline
\end{tabular}

*Analysis for a series of identical buildings tightly grouped together

A summary of the solar electric production information can be found in Table E-3.

Table E-3: Solar Electric Production by System Type at Fort Drum

\begin{tabular}{|c|c|c|c|c|c|}
\hline System Type & $\begin{array}{l}\text { Assumed } \\
\text { PV Module } \\
\text { Efficiency }\end{array}$ & $\begin{array}{l}\text { Solar Insolation, } \\
\mathrm{kWh}_{\text {(solar) }} / \mathrm{m}^{2} / \mathbf{y r}\end{array}$ & $\begin{array}{c}\text { Electric } \\
\text { Production, } \\
\text { MWh }_{\text {(electric) }} / \mathbf{y r}\end{array}$ & $\begin{array}{l}\text { Specific } \\
\text { Yield, } \\
\text { kWh/m² }\end{array}$ & $\begin{array}{l}\text { Capacity } \\
\text { Factor }\end{array}$ \\
\hline $\begin{array}{c}1 \text { MW South-Facing, } \\
\text { Latitude-Tilt, Silicon } \\
\text { PV }\end{array}$ & $18.7 \%$ & 1,530 & 1,359 & 251 & $15.5 \%$ \\
\hline $\begin{array}{c}1 \text { MW Single-Axis } \\
\text { Tracking, Silicon PV }\end{array}$ & $18.7 \%$ & 1,900 & 1,692 & 313 & $19.3 \%$ \\
\hline $\begin{array}{l}1 \text { MW Roof-Mounted } \\
\text { Silicon PV }\end{array}$ & $18.7 \%$ & 1,350 & 1,202 & 222 & $13.7 \%$ \\
\hline $\begin{array}{l}1 \text { MW Roof-Mounted } \\
\text { CdTe Thin Film PV }\end{array}$ & $11.0 \%$ & 1,350 & 1,205 & 145 & $13.8 \%$ \\
\hline $\begin{array}{l}14 \text { kW Latitude- } \\
\text { Tilted, Silicon PV } \\
\text { Array for the NCO } \\
\text { Academy }\end{array}$ & $18.7 \%$ & 1,530 & 18.0 & 238 & $14.7 \%$ \\
\hline
\end{tabular}

\section{Findings: Solar Project Economics}

Based on current average solar system costs and the projected performance for the various solar system configurations, life-cycle costs were developed for solar technologies at Fort Drum under two funding scenarios:

- Appropriated, using Energy Conservation Investment Program (ECIP) funds, and

- $\quad$ Third-party financing via an independent power producer (IPP). 
Cost-effective ECIP projects have savings-to-investment ratio (SIR) values greater than 1.0, while a $10 \%$ internal rate of return (IRR) shows whether the IPP scenario is cost-effective.

Third-party financing utilizes a third party to develop, fund, and own the projects under a power purchase agreement (PPA) or other vehicle. The third party, being a private company or utility, could take advantage of tax credits for renewable energy projects and may also sell the renewable energy credits (RECs), which in turn lower the cost required to pay for the electricity. Building-integrated PV can also be developed by a third party to take advantage of government incentives.

Solar PV arrays are generally no larger than several megawatts, and are not capable of providing base-load power because of their intermittent nature. Therefore, PV arrays can typically only displace electricity charges and not power charges. This charge is known as the marginal electric rate. The marginal electric rate at Fort Drum was calculated to be $7.54 \$ / \mathrm{kWh}$. When displacing propane-fueled electricity at the NCO Academy site, the value of electricity was calculated to be $26.0 థ / \mathrm{kWh}$.

At this time, none of the systems considered is cost-competitive. The NCO Academy 14-kW system proved to be the most cost-effective, among the systems examined, despite higher capital costs and intermittent site occupancy. The combination of the moderate solar resource, moderately low-cost energy, and high system capital costs is the principle barrier to economic solar power generation for all scenarios at Fort Drum. The SIR and simple payback for the ECIP scenario, the cost of electricity at a 10\% IRR for the IPP scenario, and the assumed system costs are shown in Table E-4 for each technology.

Table E-4: Economic Results for Solar Technologies at Fort Drum

\begin{tabular}{||l|c|c|c|c|c||}
\hline \hline Solar PV System & $\begin{array}{c}\text { Ground- } \\
\text { Mounted } \\
\text { Latitude- } \\
\text { Tilt PV }\end{array}$ & $\begin{array}{c}\text { Ground- } \\
\text { Mounted } \\
\text { Axis- } \\
\text { Tracking PV }\end{array}$ & $\begin{array}{c}\text { Roof- } \\
\text { Mounted } \\
\text { CdTe PV }\end{array}$ & $\begin{array}{c}\text { Roof- } \\
\text { Mounted } \\
\text { Si PV }\end{array}$ & $\begin{array}{c}\text { NCO } \\
\text { Academy } \\
14-k W \\
\text { Array }\end{array}$ \\
\hline $\begin{array}{l}\text { Equipment Cost } \\
\text { Assumptions, \$/kW }\end{array}$ & 5,625 & 6,625 & 4,000 & 4,500 & 8,000 \\
\hline SIR & 0.2 & 0.1 & 0.2 & 0.2 & 0.4 \\
\hline Simple Payback, yrs & 92 & 95 & 76 & 86 & 34 \\
\hline $\begin{array}{l}\text { Cost of Electricity at } \\
\text { 10\% IRR, \$/kWh }\end{array}$ & 45.5 & 43.6 & 36.8 & 41.5 & $67.5 *$ \\
\hline $\begin{array}{l}\text { Variable O\&M, } \\
\text { \$/kWh }\end{array}$ & 0.0 & 0.0 & 0.0 & 0.0 & 0.0 \\
\hline $\begin{array}{l}\text { Fixed O\&M, \$/net } \\
\text { kW }\end{array}$ & 20 & 33 & 20 & 20 & 20 \\
\hline $\begin{array}{l}\text { Federal Energy Tax } \\
\text { Credit (a credit } \\
\text { worth a percentage } \\
\text { of the expenditures) }\end{array}$ & $30 \%$ & $30 \%$ & $30 \%$ & $30 \%$ & $30 \%$ \\
\hline
\end{tabular}

* System size may preclude interest from an IPP.

\section{Solar: Next Steps}

Solar energy projects on the main post and at the NCO Academy are not cost-effective at this time because of Fort Drum's moderate solar energy resource and current PV capital costs. 
Although the economics are unfavorable, there is interest at Fort Drum in solar projects, so Fort Drum should continue to monitor the market conditions affecting solar energy, the incentives available, and the installation's energy needs so a project can be reevaluated in the future if conditions change favorably.

Advances in PV technology are expected to produce less expensive solar cells, although rising demand for PV may negate some of the potential price drop. Rising energy rates may do the most to tip the scales in favor of solar electric. Probably the most important factor in making solar electric work at a Federal installation is identifying key partners - a private developer, a utility, or both - that can provide funding, capture tax incentives, purchase or market RECs, enter into PPAs, and provide other project support.

\section{Solar Sources of Information}

DOE - U.S. Department of Energy. 1997. Renewable Energy Technology Characterizations December 1997 - Solar Parabolic Trough, Solar Power Tower, and Solar Dish Engine. TR109496, Office of Utility Technologies, Energy Efficiency and Renewable Energy, U.S. Department of Energy and Electric Power Research Institute, Inc., Washington, DC. Accessed May 2010 at http://www1.eere.energy.gov/ba/pba/tech_characterizations.html.

DOE - U.S. Department of Energy. 2010. 2008 Solar Technologies Market Report. Solar Energy Technologies Program, U.S. Department of Energy. Washington, DC. Accessed June 2010 at http://www1.eere.energy.gov/solar/pdfs/46025.pdf.

Emerging Energy Research, LTD. 2007. Global Concentrating Solar Power Markets and Strategies, 2007-2020. Emerging Energy Research, LTD., Cambridge, MA.

Minister of Natural Resources Canada. 2008. RETscreen Clean Energy Project Analysis Software. RETScreen International Clean Energy Decision Support Centre, Minister of Natural Resources Canada, Ottawa, Ontario, Canada. Accessed May 2010 at http://www.retscreen.net (last updated March 3, 2010).

NASA - National Aeronautics and Space Administration's Langley Research Center and Atmosphere Science Data Center. 2010. Surface meteorology and Solar Energy. Accessed May 2010 at http://eosweb.larc.nasa.gov/sse (last updated May 4, 2010).

NREL - National Renewable Energy Laboratory. 2008. U.S. Solar Resource Map. Accessed November 2009 at http://www.nrel.gov/gis/solar.html.

Sargent \& Lundy Consulting Group. 2003. Assessment of Parabolic Trough and Power Tower Solar Technology Cost and Performance Forecasts. NREL/SR-550-34440, prepared by Sargent \& Lundy LLC Consulting Group for the National Renewable Energy Laboratory, Chicago, IL.

Stoddard L, J Abiecunas, and R O'Connell. 2006. Economic, Energy, and Environmental Benefits of Concentrating Solar Power in California. NREL/SR-550-39291, prepared by Black \& Veatch for the National Renewable Energy Laboratory, Overland Park, KS. 
Ton D, CJ Hanley, GH Peek, and JD Boyes. July 2008. Solar Energy Grid Integration Systems Energy Storage (SEGIS-ES). Report SAND2008-4247. Sandia National Laboratories, Albuquerque, New Mexico.

Wiser R, G Barbose and C Peterman. 2009. Tracking the Sun: The Installed Cost of Photovoltaics in the U.S. from 1998-2007. LBNL-1516E, Environmental Energy Technologies Division, Lawrence Berkeley National Laboratory, Berkeley, CA. Accessed May 2010 at http://eetd.lbl.gov/ea/ems/re-pubs.html. 
E-12 
APPENDIX F

Analysis of Wind Opportunities 



\section{Appendix F: Analysis of Wind Opportunities}

\section{Wind Technology}

There is a vast wind resource in the United States. The American Wind Energy Association states that domestic wind resources, which are economically feasible in at least 46 states, could theoretically supply all of the nation's electricity needs (AWEA 2007). At the current time, however, less than $2 \%$ of the nation's power is generated from wind, though electricity generation from wind power projects continues to increase. In 2008, wind power projects accounted for $42 \%$ of all the new generating capacity installed in the United States, up from $2 \%$ of installed capacity in 2004 (AWEA 2009).

Wind projects, often referred to as wind farms, can be categorized by scale. Large, utility-scale projects tend to be $50 \mathrm{MW}$ and above, with the world's largest single wind farm being in Texas at over $700 \mathrm{MW}$. Smaller-sized projects (under $50 \mathrm{MW}$ ) are often referred to as community wind projects or distributed generation (DG) projects. Community wind projects involve local ownership structures, often with corporate partners taking advantage of the Federal production tax credit. DG projects are designed to offset the owner's retail electricity purchases by producing power that is used on site, with any surplus sold to a commercial utility.

Wind turbines come in many different sizes and configurations. Wind turbines in the U.S. generally employ the Danish configuration - a horizontal-axis, three-bladed rotor, an upwind orientation, and an active yaw system to keep the rotor oriented into the wind.

Utility-scale turbines for bulk power production tend to be $660 \mathrm{~kW}$ to $3 \mathrm{MW}$ in size. Hub heights can range from 50 meters (164 feet) to 100 meters (328 feet). Industrial turbines for consumer and remote grid production are found in the range of $50 \mathrm{~kW}$ to $250 \mathrm{~kW}$. Hub heights range between 25 meters ( 80 feet) and 40 meters (131 feet). Residential-scale wind turbines are used for remote power, battery charging, or net-metering generation. These turbines tend to be 400 watts to $50 \mathrm{~kW}$. For turbines greater than $1 \mathrm{~kW}$, the hub heights range from 12 meters (40 feet) to 36 meters (120 feet).

The land required for a single utility-scale wind turbine is typically 3 acres, including access roads, turbine base, and other equipment. A wind turbine located on a ridgeline in hilly terrain will require less area than one on flat land, as little as 2 acres per MW. The proper spacing of turbines is essential to reduce wake interference and optimize the wind resource. In open flat terrain, a utility-scale wind plant will require a buffer space of about 60 acres per MW of installed capacity.

Although more difficult to finance and lacking in economies of scale, smaller-sized wind generation projects offer some potential benefits over large-scale wind farms:

$\checkmark$ A smaller project is often easier to permit and may be less likely to interfere with other land uses (including military missions).

$\checkmark$ On-site power generation that is integrated into the site electrical system provides energy security. 
$\checkmark \quad$ It may be possible to avoid building a costly substation if a suitably sized power interconnection is located near a promising site for wind turbines.

\section{Wind Analysis Approach}

2005 DoD Assessment Approach

The DoD Renewables Study relied upon wind resource maps developed by the National Renewable Energy Laboratory (NREL), maps developed by independent companies, and PNNL's Wind Energy Resource Atlas of the United States to identify the installations with best potential for commercial-scale wind farms. The DoD analysis used the highest resolution map available for each state to quantify the wind resource on the military land in that state. Over 70 Army and Air Force installations were reviewed with respect to both wind resource and compatibility with the installation's mission. About 20 installations with potential for projects were selected for follow-on detailed assessments. Fort Drum was not included in that study.

\section{PNNL Assessment Approach}

In 2004, PNNL completed a feasibility assessment for wind power generation at Fort Drum and provided technical assistance in procuring and installing wind monitoring equipment on site, analyzing wind data and assessing the viability of a wind power plant at Fort Drum as part of the Federal Energy Management Program (FEMP) Technical Assistance program (Schienbein 2004). The analyzed data collected from the on-site meteorological tower (met tower) is used in this updated analysis.

\section{Updated Wind Analysis Approach}

For this updated analysis, PNNL used the following approach to analyze the economic potential for wind energy at Fort Drum. More detail on the financing scenarios, generic analytic approach, and economic and other parameters used in this analysis are documented in Appendix A of this report.

(1) Wind resource maps and available on-site data were analyzed.

(2) Existing on-site interconnection and transmission capacity and availability were evaluated.

(3) Local wind developer activity in the area was surveyed to assess potential interest in developing projects.

(4) A turbine model was selected to establish cost and performance parameters.

(5) Total project cost was estimated, including project development, generation equipment, balance of plant construction, interconnection and transmission, operation and maintenance (O\&M), taxes, and tax credits and other policy incentives.

(6) Economic feasibility was determined utilizing different financing scenarios: independent power producer (IPP) and Energy Conservation Investment Program (ECIP).

(7) Project feasibility was determined and next steps recommended. 


\section{Wind Resource Characterization}

According to industry standards developed as part of the Wind Energy Resource Atlas of the United States, there are seven main classes of wind power, as shown in Table F-1.

Table F-1: Classes of Wind Power Density at $\mathbf{5 0}$ Meters

\begin{tabular}{||c|c|c||}
\hline $\begin{array}{c}\text { Wind } \\
\text { Power } \\
\text { Class }\end{array}$ & $\begin{array}{c}\text { Wind Power } \\
\text { Density, } \\
\text { W/m }\end{array}$ & Speed, m/s (mph) \\
\hline $\mathbf{1}$ & $<200$ & $<5.6(12.5)$ \\
\hline $\mathbf{2}$ & $200-300$ & $5.6(12.5)-6.4(14.3)$ \\
\hline $\mathbf{3}$ & $300-400$ & $6.4(14.3)-7.0(15.7)$ \\
\hline $\mathbf{4}$ & $400-500$ & $7.0(15.7)-7.5(16.8)$ \\
\hline $\mathbf{5}$ & $500-600$ & $7.5(16.8)-8.0(17.9)$ \\
\hline $\mathbf{6}$ & $600-800$ & $8.0(17.9)-8.8(19.7)$ \\
\hline $\mathbf{7}$ & $>800$ & $>8.8(19.7)$ \\
\hline
\end{tabular}

A strong Class 3 resource, preferably Class 4, is generally required to achieve an economic project on a large, commercial scale. According to the New York Wind Resource Map in Figure F-1 (NREL 2010), Fort Drum has $6.0-7.0 \mathrm{~m} / \mathrm{s}$ wind at $80 \mathrm{~m}$, which defines the site as a having a Class 2 to 3 wind resource.

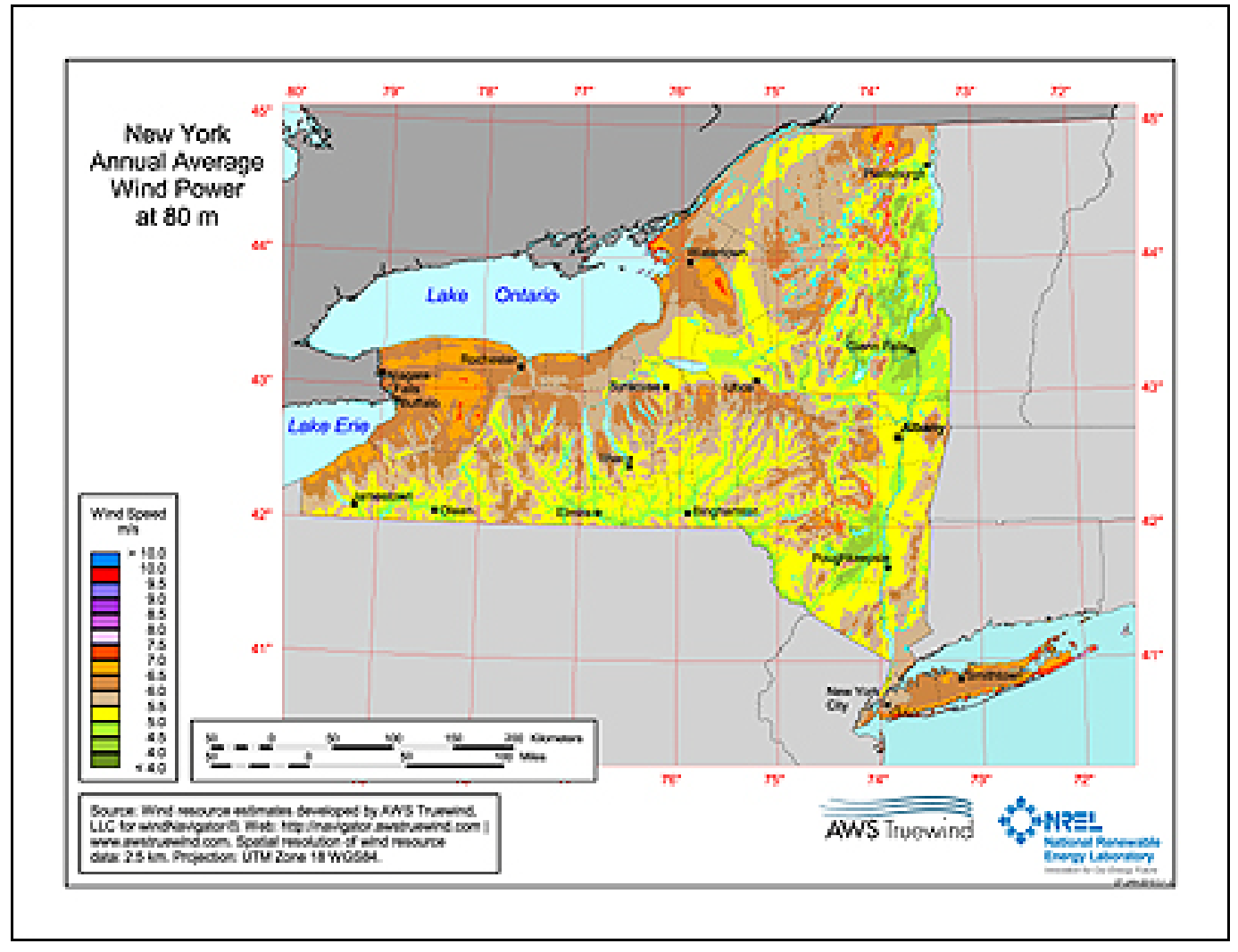

Figure F-1: New York Wind Resource Map 
As part of the 2004 FEMP analysis, a 40-m met tower was installed on the northern side of Fort Drum's property. The met tower collected wind data for one year. The observed mean wind speed at $40 \mathrm{~m}$ was $4.73 \mathrm{~m} / \mathrm{s}$. The long-term adjusted mean, based on long-term reference stations, was calculated to be $4.76 \mathrm{~m} / \mathrm{s}$ at $40 \mathrm{~m}$. And the long-term adjusted mean at $100 \mathrm{~m}$, based on the calculated wind shear exponent of the site, was calculated to be $6.44 \mathrm{~m} / \mathrm{s}$ (AWS Truewind 2004).

Table F-2 summarizes Fort Drum’s wind resource according to the available data sources.

Table F-2: Summary of Wind Resource Data

\begin{tabular}{||c|l|l||}
\hline Location & \multicolumn{1}{|c|}{ Source } & \multicolumn{1}{c|}{ Wind Speed } \\
\hline \multirow{2}{*}{ Fort Drum, New York } & New York Wind Resource Map & $6.0-7.0 \mathrm{~m} / \mathrm{s}$ at $80 \mathrm{~m}$ \\
\cline { 2 - 3 } & $40-\mathrm{m}$ Met Tower Data & $4.76 \mathrm{~m} / \mathrm{s}$ at $40 \mathrm{~m}, 6.44 \mathrm{~m} / \mathrm{s}$ at $100 \mathrm{~m}$ \\
\hline
\end{tabular}

\section{Siting Considerations}

After wind resource availability, the primary siting consideration for grid-connected wind projects is transmission availability and the capacity of those lines. Projects need to be located within approximately 1 mile of existing transmission lines, or new lines will need to be constructed at considerable cost.

Another consideration is potential interference with airport operations. The Federal Aviation Administration (FAA) requires Notice of Proposed Construction for a project that meets certain criteria so that it can determine if there would be adverse impacts to air navigation safety. One of the triggering criteria is whether the project would be located within 20,000 feet (3.8 miles) or less of an existing public or military airport. When selecting an area for a wind project, it would be best to avoid this potential interference issue by locating the project outside of the 20,000-foot range. Any potential wind project would need to carefully consider this concern. An additional FAA criterion that would necessitate a Notice of Proposed Construction is any construction or alteration of more than 200 feet (61 meters) in height above ground level. This criterion applies regardless of the distance from the proposed project to an airport.

In response to the filing of a Notice of Proposed Construction, the FAA can either require modifications be made to the project or a "No Hazard to Air Navigation" determination can be issued and the wind project can proceed.

Related to airport operations are radar and training operations. The 3-MW wind project that was to be built as a result of the 2004 feasibility study did not proceed because of concerns that the project would interfere with Fort Drum's radar operations. Because of this, Fort Drum is only currently interested in small wind projects.

A site-specific radar impact study could be done to determine the exact impact or large-scale wind and address potential mitigation efforts, if required. From PNNL's review of the correspondence on the issue, it does not appear that any site-specific study was done or that the decision that a wind project would have an impact on the radar systems was data-driven. 
Gary Seifert at Idaho National Laboratory (INL) indicated that INL has helped nine projects in the vicinity of Fort Drum successfully address radar impact concerns so that the projects could proceed. A similar study could be done for Fort Drum, if desired. In addition, much may have changed in the years since the project was cancelled.

This analysis considers three possible project sites: 1) large wind on the main property of Fort Drum; 2) small wind on the main property of Fort Drum, possibly at the Zero Energy Building that is in planning; and 3) small wind at the remote Non-Commissioned Officers (NCO) Academy training site.

The NCO Academy is an off-grid site surrounded by trees. The tallest trees are estimated to be about $18 \mathrm{~m}$ (60 feet). A 30-m hub height (98 feet) is the 10-kW turbine manufacturer's recommended tower height and also the minimum required for the turbine to clear the tree line. Because of the limited space and tall trees, if Fort Drum is interested in pursuing a small wind project at this site, additional site analysis will be required.

A final siting concern is that the Indiana bat resides on Fort Drum property and is an endangered species. No logging or construction work can take place in the on-site forests from April 1 to October 1 so as not to interfere with bat life. The US Fish \& Wildlife Service's Biological Opinion of Fort Drum does not include any "bat take." That means no bats are "allowed" to die at Fort Drum (from a wind project, for example) without a modification to the Opinion first.

According to discussions with Fort Drum personnel, small wind turbines are not expected to necessitate a modification or have any impact on the bats. This evaluation will have to be formalized by the Fort Drum National Environmental Policy Act (NEPA) biologist if Fort Drum decides to pursue a wind project.

\section{Wind: Economic and Other Analysis Parameters}

This assessment considered the current Federal wind incentives: a 2.1 $\mathbb{k} / \mathrm{kWh}$ renewable energy production tax credit (PTC) and 5-year accelerated depreciation. State-specific incentives applicable to wind energy projects for New York are also included and discussed in Appendix A.

During the DoD renewable energy assessment in 2005, the installed cost of capital was approximately $\$ 1,400 / \mathrm{kW}$; at the current time, prices range from $\$ 1,700$ to $\$ 2,600 / \mathrm{kW}$ because of high demand and increased costs for components. The capital cost was assumed to be $\$ 2,337 / \mathrm{kW}$ (including incentives and taxes) for this economic assessment for a large wind project.

This analysis does not include any transmission costs and assumes that existing transmission lines are available to transmit power without substantial additional investment. It is also assumed that an on-site wind project would not trigger new standby or other fees from the local utility. But because wind is intermittent, the utility may have interconnection requirements to ensure grid stability and to ensure there is reliable power for the installation.

For the small wind economic assessment, a $\$ 6,465 / \mathrm{kW}$ (including incentives and taxes) capital cost was used for a 10-kW turbine. To assess the potential of small wind, Fort Drum requested 
that a turbine in the 5- to $10-\mathrm{kW}$ size range be used. The $10-\mathrm{kW}$ turbine size was selected by PNNL for its pricing and power curve information availability. Fort Drum is also interested in the possibility of using small vertical-axis wind turbines (VAWT), but VAWT pricing and power curve information was not available to be included in this analysis.

The 10-kW wind turbine may produce more energy than is needed at the NCO Academy site because of the site's intermittent use, or it may not produce enough or any energy while the site is being used if the coincident wind available is insufficient.

To account for this mismatch in supply and load, Fort Drum could install a battery storage system, but that cost was not considered in this analysis. Ultimately, including the cost of a battery system in the economic analysis will drive the cost of energy of the wind project higher.

Because a wind energy project would provide intermittent power to the installation, the economics of a wind project are evaluated against the installation's direct energy charge of

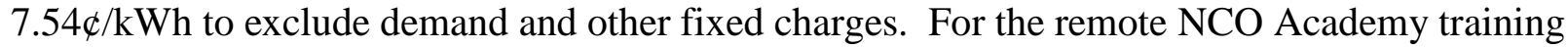
site, potential projects are there evaluated against the energy cost of the on-site propane-fueled generators, $26.0 \$ / \mathrm{kWh}$.

The mean wind speed and net capacity factor determined in the 2004 FEMP analysis were reused in this updated analysis.

Further details on the analysis methodology and the economic and incentive parameters are documented in Appendix A, and the assumptions used are listed in Table F-3.

Table F-3: Performance, Cost, and Economic Characteristics

\begin{tabular}{|c|c|c|c|}
\hline Location & On-Site Large Wind & On-Site Small Wind & $\begin{array}{l}\text { Remote Small Wind at } \\
\text { NCO Academy }\end{array}$ \\
\hline Conditions & $\begin{array}{l}1.219 \mathrm{~kg} / \mathrm{m}^{3} \text { air density } \\
\text { at } 40 \mathrm{~m}, 162 \mathrm{~m} \text { ASL }\end{array}$ & $\begin{array}{l}\text { Standard: } 1.255 \mathrm{~kg} / \mathrm{m}^{3} \\
\text { air density, } 0 \mathrm{~m} \mathrm{ASL}\end{array}$ & $\begin{array}{l}\text { Standard: } 1.255 \mathrm{~kg} / \mathrm{m}^{3} \\
\text { air density, } 0 \mathrm{~m} \text { ASL }\end{array}$ \\
\hline Assumed Average Wind Speed & $6.44 \mathrm{~m} / \mathrm{s}$ at $100 \mathrm{~m}$ & $4.24 \mathrm{~m} / \mathrm{s}$ at $30 \mathrm{~m}$ & $4.24 \mathrm{~m} / \mathrm{s}$ at $30 \mathrm{~m}$ \\
\hline Net Capacity Factor & $26 \%$ & $10.1 \%$ & $10.1 \%$ \\
\hline Turbine Type & $\begin{array}{l}\text { 1.5 MW, } 77 \mathrm{~m} \text { rotor, } 100 \\
\mathrm{~m} \text { hub height }\end{array}$ & $\begin{array}{l}10 \mathrm{~kW}, 7 \mathrm{~m} \text { rotor, } 30 \mathrm{~m} \\
\text { hub height }\end{array}$ & $\begin{array}{l}10 \mathrm{~kW}, 7 \mathrm{~m} \text { rotor, } 30 \mathrm{~m} \\
\text { hub height }\end{array}$ \\
\hline Project Size & 1 turbine & 1 turbine & 1 turbine \\
\hline $\begin{array}{l}\text { Estimated Net Annual Energy } \\
\text { Production }\end{array}$ & 3,461,000 kWh/yr & 8,875 kWh/yr & $8,875 \mathrm{kWh} / \mathrm{yr}$ \\
\hline Energy Charge & $7.54 \& / \mathrm{kWh}$ & $7.54 \$ / \mathrm{kWh}$ & 26థ/kWh \\
\hline Total Capital Cost & $\$ 2,337 / \mathrm{kW}$ & $\$ 6,465 / \mathrm{kW}$ & $\$ 6,465 / \mathrm{kW}$ \\
\hline Fixed O\&M Cost & $\$ 60 / \mathrm{kW}$ & $\$ 8.90 / \mathrm{kW}$ & $\$ 8.90 / \mathrm{kW}$ \\
\hline 5-year accelerated depreciation & Included & Included & Included \\
\hline Federal 2.14/kWh PTC & Included & Included & Not Included \\
\hline NYSERDA Rebate & Not Included & $\$ 24,305$ & Not Included \\
\hline RECs & Not Included & Not Included & Not Included \\
\hline Transmission Costs & Not Included & Not Included & Not Applicable \\
\hline
\end{tabular}




\section{Findings: Wind}

The various energy cost scenarios were evaluated for ECIP eligibility and IPP project potential. To qualify for ECIP funding, a project must achieve a savings-to-investment ratio (SIR) of 1.0, and its payback is also examined. For the IPP evaluation, the commercial cost of energy was calculated to obtain an internal rate of return (IRR) of $10 \%$. This was used as the minimum IRR required to attract the interest of a wind power project developer. Table F-4 lists the results of these analyses.

Table F-4: Economic Assessment of Wind Power

\begin{tabular}{|c|c|c|c||}
\hline \multirow{2}{*}{ Financing Scenario } & \multicolumn{2}{|c||}{ ECIP } & IPP \\
\hline Economic Factor & SIR & $\begin{array}{c}\text { Simple Payback, } \\
\text { years }\end{array}$ & $\begin{array}{c}\text { Cost of Electricity at 10\% } \\
\text { IRR, (k/kWh }\end{array}$ \\
\hline On-Site Large Wind & 0.57 & 24.6 & 59.92 \\
\hline $\begin{array}{c}\text { On-Site Small Wind } \\
\text { Remote Small Wind at NCO } \\
\text { Academy }\end{array}$ & 0.18 & 79.4 & 99.13 \\
\hline
\end{tabular}

\section{Wind: Next Steps}

Given the current cost assumptions, a large-scale wind energy project at Fort Drum has marginal economics. The cost of energy required to achieve a 10\% IRR is double what Fort Drum is currently paying. It is not recommended that Fort Drum pursue a large-scale wind energy project at this time. However, if capital costs were to decrease or if more incentives become available, Fort Drum should reconsider large-scale wind.

Fort Drum has requested wind studies from both the Office of the Assistant Chief of Staff for Installation Management (OASCIM) and New York State Energy Research and Development Authority (NYSERDA) to be conducted in fiscal year 2011. Either of these studies would provide Fort Drum another opportunity to examine wind energy project potential. The NYSERDA study would also help Fort Drum identify the best incentives available from NYSERDA, such as rebates and REC purchasing, that will improve project economics.

The small wind turbine cases had less economic potential because of the higher capital costs and lower energy production of small systems.

While a large wind project at Fort Drum is currently unlikely and a small project would be costly and only contribute a small amount of electricity, it could provide other benefits. Installing a wind turbine can immediately bring attention from the local community to a site's commitment to renewable energy, if for no other reason than wind energy has become synonymous with "going green." 
Other considerations are that the cost of wind power is not dependent upon the cost of fossil fuels, and a wind project may provide a small level of energy security.

Additionally, a small wind project on site could be used as a demonstration project, for example at the proposed Zero Energy Building. A small wind turbine could offset a portion of the building's energy consumption.

Fort Drum is in discussion with a couple of VAWT manufacturers who may be willing to donate prototype products to Fort Drum because they are in need of demonstration and testing sites. If Fort Drum were to accept a free VAWT, the expectations going in to the project would have to be clear. It would have to be agreed that Fort Drum is providing a site for the manufacturer to test its unproven technology. There is concern that if a wind technology is implemented and doesn't work, it will take a long time to turn around public perception about wind at Fort Drum.

\section{Wind Sources of Information}

AWEA - American Wind Energy Association. 2007. Wind Power Today. Accessed May 2010 at http://www.awea.org/pubs/factsheets/WindPowerToday_2007.pdf.

AWEA - American Wind Energy Association. 2009. Wind Power Outlook. Accessed May 2010 at http://www.awea.org/pubs/documents/Outlook_2009.pdf.

AWS Truewind. 2004. Fort Drum Wind Resource Assessment Report. AWS Truewind, Albany, New York.

Conover K, KJ Smith, and TM Jurotich. November 15, 2004. U.S. Department of Defense Renewable Energy Assessment Report of Wind Energy Potential On and Near Military Installations. Global Energy Concepts, Kirkland, Washington.

FAA - Federal Aviation Administration. 2007. Advisory Circular: Obstruction Marking and Lighting. AC 70/7460-1K, Federal Aviation Administration, Washington, DC. Accessed May 2010 at http://www.airweb.faa.gov/Regulatory_and_Guidance_Library/rgAdvisoryCircular.nsf/0/b993dc dfc37fcdc486257251005c4e21/\$FILE/AC70_7460_1K.pdf.

NREL - National Renewable Energy Laboratory. 2010. New York Wind Resource Map. Prepared by the NREL for the U.S. Department of Energy, Washington, DC. Accessed April 2010 at http://www.windpoweringamerica.gov/images/windmaps/ny_80m.jpg (last updated January 27, 2010).

PNL - Pacific Northwest Laboratory. 1986. Wind Energy Resource Atlas of the United States. Solar Technical Information Program \& Solar Energy Research Institute, Golden, Colorado. Accessed May 2010 at http://rredc.nrel.gov/wind/pubs/atlas/atlas_index.html.

Schienbein L. 2004. Technical Assistance: Wind Energy Evaluation, Fort Drum, New York. Pacific Northwest National Laboratory, Richland, Washington. 


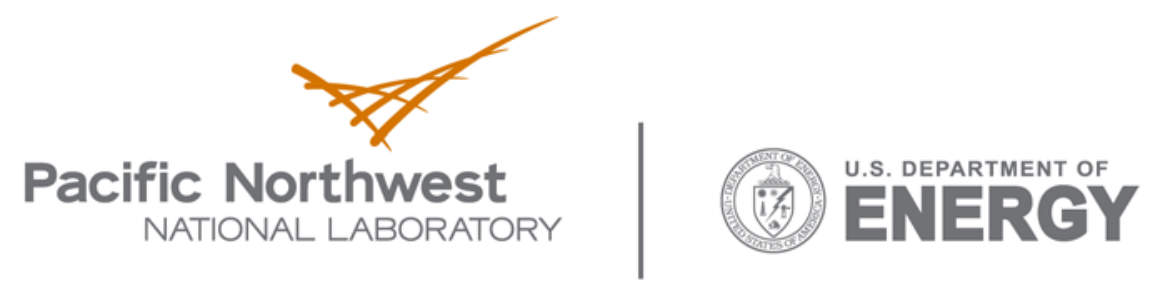

902 Battelle Boulevard

P.O. Box 999

Richland, WA 99352

1-888-375-PNNL (7665)

www.pnl.gov 